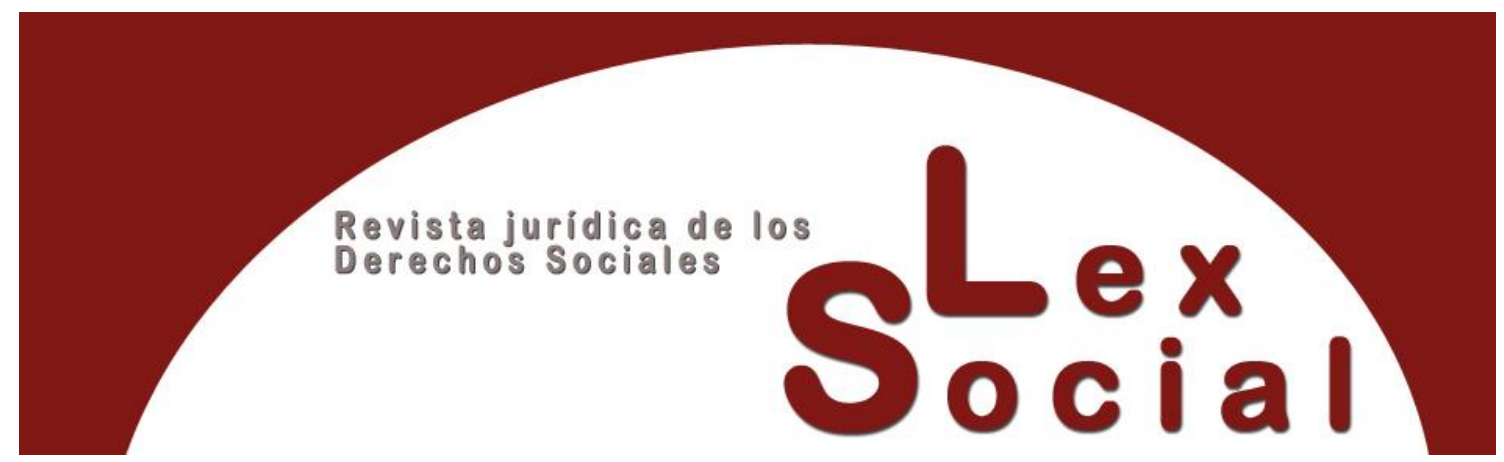

\title{
TEORÍA SOCIO-JURÍDICA DEL ESTADO CONSTITUCIONAL Y SINDICALISMO DE INTEGRACION: LA CONCEPCIÓN DE ADOLFO POSADA
}

\section{SOCIO-JURIDICAL THEORY OF THE CONSTITUTIONAL STATE AND INTEGRATION SYNDICALISM: THE CONCEPTION OF ADOLFO POSADA}

\author{
JOSÉ LUIS MONEREO PÉREZ \\ Catedrático de Derecho del Trabajo y Seguridad Social \\ Universidad de Granada \\ https://orcid.org/0000-0002-0230-6615
}

Cómo citar este trabajo: Monereo Pérez, J.L (2022). Teoría socio-jurídica del estado constitucional y sindicalismo de integración: la concepción de Adolfo Posada. Lex Social, Revista De Derechos Sociales 12 (1), pp. 347-435. https://doi.org/10.46661/lexsocial.6330

\section{RESUMEN}

El republicanismo social reformista e intervencionista de Adolfo Posada es sin duda un liberalismo social democrático, incluso cuando defendió la democracia constitucional en el cuadro de una reforma de las instituciones políticas liberales. Adolfo Posada defiende una singular "democracia orgánica" liberal y pluralista, basada en el respecto de los derechos políticos, civiles, económicos, sociales y culturales de una ciudadanía plena. Adolfo Posada defiende un republicanismo de los derechos y libertades fundamentales en el marco de una democracia constitucional basada en el pluralismo político y social; y contando, por tanto, con la participación activa de los ciudadanos y de los grupos y organizaciones sociales de intereses comunes solidarios donde aquéllos desarrollan su personalidad integral y que hacen posible (condición de posibilidad) su autorrealización plena como ciudadanos en la comunidad de pertenencia (democracia pluralista, funcional y 
social). En la democracia constitucional tienen un papel central las organizaciones profesionales y en particular el sindicato como sujeto sociopolítico.

Palabras Clave: Adolfo Posada, republicanismo social, liberalismo social, democracia constitucional, teoría social y jurídica del Estado; Estado Social y Jurídico (Estado Social de Derecho); Constitución Social; derechos económicos, sociales y culturales; Derecho Social del Trabajo y de la Seguridad Social; sindicalismo reformista; sindicalismo revolucionario.

\begin{abstract}
Adolfo Posada's reformist and interventionist social republicanism is undoubtedly a democratic social liberalism, even when he defended constitutional democracy in the context of a reform of liberal political institutions. Adolfo Posada defends a unique liberal and pluralistic "organic democracy" based on respect for the political, civil, economic, social and cultural rights of full citizenship. Adolfo Posada defends a republicanism of fundamental rights and freedoms within the framework of a constitutional democracy based on political and social pluralism; And counting, therefore, on the active participation of citizens and social groups and organizations of common solidarity interests where those develop their integral personality and make possible (condition of possibility) their full self-realization as citizens in the community of belonging (pluralistic, functional and social democracy). In constitutional democracy, professional organizations and in particular the trade union as a socio-political subject have a central role.
\end{abstract}

KeYWORDS: Adolfo Posada, social republicanism, social liberalism, constitutional democracy, social and legal theory of the State; Social and Legal State (Social Rule of Law); Social Constitution; economic, social and cultural rights; Social Labor and Social Security Law; reformist trade unionism; revolutionary trade unionism.

\title{
SUMARIO
}

1. Una aproximación al pensamiento de Adolfo González Posada.

2. La concepción organicista del Estado y el republicanismo social de Adolfo Posada.

3. Reforma de la "Constitución política" en el sentido de la implantación de un sistema democrático ante la crisis del sistema liberal: La "democracia orgánica" del republicanismo democrático-social krausista.

4. La transformación de los mecanismos de representación en el Estado democrático: representación política y representación de intereses específicos ("Parlamento social o Cámara social"). 
5. Obras de Adolfo González Posada, su pensamiento y época.

"En una sociedad que se distingue por la desigualdad está sujeta a denegar libertad a sus miembros y, por lo tanto, a provocar conflictos.

Los valores sociales serán desfigurados de tal manera, y el aparato montado para magnificar esa esa desfiguración será tan vasto, que el gobierno quedará ciego ante las realidades que se le enfrentan"

HAROLD J. LASKI ${ }^{1}$

\section{1.-Una aproximación al pensamiento de Adolfo González Posada}

Adolfo González Posada (1860-1944), cuyo nombre completo es Adolfo González Posada y Biesca, nace en Oviedo, el 18 de septiembre de 1860 y muere en Madrid, el 8 de julio de 1944. Es, sin duda, uno de los más importantes e influyentes iuspublicistas europeos del siglo veinte; y en esa condición tuvo una participación activa determinante en el reformismo jurídico-social y en la defensa del constitucionalismo democrático-social con Estado Social de Derecho². Él optó por abreviarlo su nombre en la síntesis: "Adolfo Posada", denominación, ésta, con la que solía firmar en su vida profesional. En 1874 Posada comienza su licenciatura en Derecho en la Facultad de Derecho de la Universidad de Oviedo. El joven Posada se desarrolla en un ambiente propio de la burguesía liberal. "Mi familia -nos dicepertenecía a la burguesía modesta del comercio. La casa de mis padres, joyería y platería, se formará alrededor de un taller de diamantista, fundado y sostenido por mi abuelo y convertido en tienda de joyas por mi padre -antes dependiente y viajante de una gran joyería de Valladolid. El naciera en Otero de las Dueñas, a seis leguas de León, de familia de campesinos de origen asturiano..." (Fragmentos de mis Memorias) ${ }^{3}$.

Obtiene el grado de licenciado en 1878. Realiza la tesis doctoral en Madrid, bajo la atenta dirección de Francisco Giner, sobre las Relaciones entre el Derecho natural y el Derecho positivo. En Madrid entra en contacto con la Institución Libre de Enseñanza y con el Ateneo (El Presidente del Ateneo, José Moreno Nieto, sería también presidente del Tribunal de doctorado de Posada). Influyen en su formación personalidades tan relevantes como Adolfo Álvarez Buylla y Leopoldo Alas “Clarín”. En 1883 se presenta, y obtiene, la cátedra vacante

${ }^{1}$ LASKI, H.J.: La libertad en el Estado moderno, trad. Eduardo Warshaver, revisión, edición y estudio preliminar, "Harold J. Laski y las trayectorias del socialismo democrático en el mundo anglosajón" (pp. IX-XCVII), a cargo de J.L. Monereo Pérez, Granada, Ed. Comares (Col. Crítica del Derecho), 2021, pág. 163.

${ }^{2}$ MONEREO PÉREZ, J.L.: La reforma social en España: Adolfo Posada, Madrid, Ministerio de Trabajo y Asuntos Sociales, 2003, espec., capítulo I ("La teoría jurídico-social del Derecho y del Estado en el pensamiento de Adolfo Posada"), págs. 31-131.

${ }^{3}$ POSADA, A.: Fragmentos de mis Memorias, Oviedo, Universidad de Oviedo, Cátedra Aledo, 1983. 
de Derecho político y administrativo español de la Universidad de Oviedo. Tenía, por entonces, veintitrés años. Fue catedrático de Derecho político de la Universidad de Oviedo durante veinte años (en 1904 abandona Oviedo). En el año 1904 se traslada a Madrid, trabajando en el Instituto de Reformas Sociales hasta 1923; fecha en la que desaparece por decisión del General Primo de Rivera. Tras el golpe de Estado, Posada dimite de todos los cargos que ostentaba en organismos oficiales (Senado, Instituto de Reformas Sociales, Instituto Nacional de Previsión y Consejo de Instrucción Pública), manteniendo solamente la cátedra de la Universidad Central. Desde 1919 pasó a explicar Derecho Municipal en Madrid, y después Derecho Político hasta su jubilación como catedrático en 1931, pero es designado como Decano en funciones de la Facultad de Derecho de la Universidad Central. Presidirá también el Consejo de Estado, órgano asesor del Ministerio en materia de conflictos sociales, y, desde 1935, ostentaría la presidencia del Instituto Nacional de Previsión. En el año1936, el Gobierno del Frente Popular destituye a Adolfo Posada de su Decanato y, posteriormente, de la presidencia del Instituto Nacional de Previsión. Los años de la guerra (in)civil transcurren en San Juan de Luz; en 1939 regresa a Madrid, donde muere en 1944. Es uno de los grandes iuspublicistas europeos entre los dos siglos, que contribuyen a cerrar y a abrir una época en los modos de pensar jurídico y político. Se suma a la excelente hornada formada por Anschütz, Duguit, Hauriou ${ }^{4}$, Orlando, Santi Romano, en la transición de los dos siglos. Formó parte del conocido "Grupo de Oviedo", el corazón del krausismo jurídico español. Fue, sin duda, una de las figuras más destacadas de la "edad de oro" de la Universidad de Oviedo, y una de las figuras señeras del pensamiento krausista, el cual supo adaptar a las nuevas exigencias del tiempo en su larga vida. Pero también debe considerarse a Posada como uno de los fundadores de la sociología como ciencia en España, en la época de transición de modos de organización social. Él supo, marcando diferencias con muchos krausistas de su tiempo, conjugar pensamiento y acción desde su ideario krausista de armonía y diálogo social; y no puede precisamente considerarse como una "faceta secundaria en su vida" -destinado como estaba a lograr edad longeva- su papel de actuación política y administrativa en acción, porque una gran parte de su vida profesional activa la dedicó, desde el compromiso político intelectual, a la reforma social de la legislación y de la estructura administrativa del Estado. Es necesario diferenciar entre actividad política y pertenencia a partido político, porque Posada actuó fuera de los partidos, aunque en algunos casos tuvo una especial vinculación como ahora se verá. Fue discípulo de Giner de los Ríos, señalado que "Toda mi vida profesional, y en ella mi modesta labor de cultivador de disciplinas del Estado, giró alrededor del curso Principios de Derecho político de Giner; un Derecho político de abolengo Krausista, sin duda, por su base ética, sus supuestos metafísicos y su sentido esencialmente orgánico, pro de una profunda originalidad frente a

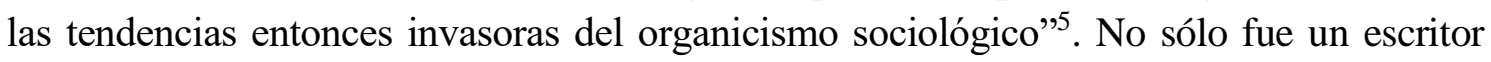

\footnotetext{
${ }^{4}$ HAURIOU, M.: Principios de Derecho Público y Constitucional, traducción, estudio preliminar, notas y adiciones por Carlos Ruiz del Castillo, edición al cuidado de J.L. Monereo Pérez, Granada, Comares (Col. Crítica del Derecho), 2003.

${ }^{5}$ POSADA,A.: Breve historia del krausismo español, Oviedo, Universidad de Oviedo. Servicio de Publicaciones, 1981.
} 
fecundo (sus publicaciones rebasan los trescientos títulos), sino que también su obra se caracteriza por la amplitud temática y el frecuente rasgo de la interdisciplinariedad.

Por otra parte, Adolfo Posada mantuvo una labor especialmente activa en el Partido Reformista, de cuya Junta Nacional fue miembro desde su creación. Este Partido Reformista estaba encabezado por Melquíadez Álvarez y proponía un programa de reforma política y de transformación del sistema de Derecho liberal en sistema de Derecho social que convenía especialmente al ideario propio de Posada. De hecho, Melquídez Álvarez, en muchos aspectos, puede ser considerado como realizador del proyecto reformista que Posada había defendido durante largo tiempo antes. Posada intervino en la estructura directiva interna del partido reformista, el 29 de abril de 1914 la Junta Nacional estaba formada, entre otros, por José Fernando González, Jacinto Octavio Picón, José Jackson Veyan, Práxedes Zancada, Eusebio Corominas, Álvarez Prida, Castellanos, Luis Zulueta, José Ortega y Gasset, Simarro, Teófilo Hernando, Gustavo Pittaluga, Manuel García Morente, Rodríguez Pinilla, Adolfo G.Posada, Leopoldo Palacios, Federico de Onís, el marqués de Palomares del Duero, Rafael Sánchez Ocaña, Manuel Azaña, Augusto Barcia, Miguel Moya Gastón, Fábregas y Flores. Era, pues, dominante la presencia de los reformistas institucionistas. En las elecciones generales de 1923, Adolfo Posada salió elegido como diputado por Asturias en las filas del reformismo. El día 24 de mayo de 1923, Melquíadez Álvarez sería elegido presidente del Congreso, en un momento crítico para la vigencia del parlamentarismo en España; y, en efecto, el 13 de septiembre de 1923, Miguel Primo de Rivera hizo triunfar su golpe de Estado contra el orden constitucional que estaba siendo ya gravemente amenazado desde sectores y fuerzas bien definidas. Su resultado fue la instauración del Directorio Militar en el poder y la suspensión de las garantías constitucionales decretada el día 15 de septiembre de aquél año. Posada sería Senador independiente por el Partido Reformista entre 1921 y 1923, aunque su actividad en ese cometido no fuese especialmente intensa, ya que se dedicó mayormente a las laborales de su Cátedra de la Universidad Central. También participó, aunque con poco éxito en sus propuestas, en el proceso de reforma constitucional de la II República. Perteneció a la Comisión Jurídica Asesora encargada de elaborar la Constitución; y todavía durante la II República mantuvo -aunque marginado, a modo de un “exilio interior"- la Presidencia del Consejo de Trabajo y en 1935 ocupó, a su vez, la Presidencia del Instituto Nacional de Previsión.

Creía en la función del intelectual comprometido pero tolerante, de ahí que afirmara: "Pero el síntoma más alarmante y más significativo del momento crítico actual ha de verse en la actitud intelectual de numerosos grupos densos del mundo que llamamos "intelectual", de los "escritores"; actitud de militantes agresivos mezclados en las luchas pasionales y, por tanto, incapacitados para el cultivo sereno y desinteresado de la verdad por la verdad misma, independientemente de sus efectos políticos inmediatos; función propia del filósofo, que mira hacia arriba y hacia lo universal". En un precioso artículo fechado en 1923, intitulado "Fantasía política" decía: "Y él, que no ha hecho jamás política activa, de partido, de militante, pero que probablemente no ha hecho otra cosa que política, en sus mejores horas, desde su casa, en la intimidad con los suyos, con sus discípulos queridos y con el noble 
ejemplo de una vida sana, austera, dedicada al hombre, él contemplaba con amargura y entonces hasta con desánimo; él, tan animoso, de qué suerte se realizaban sus aprensiones y en qué triste forma la frivolidad de los seudo-políticos diera sus ingratos frutos". Para añadir, de modo harto significativo, que "El maestro, para quien la política es un problema de dignada moral, que estima primeros valores el derecho y la libertad, que no concibe política sin ética (antimaquiavelismo puro), sentíase anonadado al ver el mezquino aprecio, cuando no el desprecio, con que tantas gentes consideraban los que él reputaba más altos valores humanos, ya que sólo, merced a ellos, puede el hombre "hombresarse" frente a la escala... zoológica".

Era un hombre culto (y no sólo por su extraordinaria cultura jurídica, política, sociológica y jurídica), reflexivo y apasionado a un tiempo, que quiso buscar la mayor parte posible de la experiencia existencial e intelectual del hombre contemporáneo. Era un hombre de cultura atenta a los fenómenos políticos y sociales de su tiempo. Su vida fue multifacética, en su condición de catedrático de universidad, publicista y experto en política social, estuvo presente en instituciones y acontecimientos fundamentales de la historia de nuestro país, y mantuvo estrechos contactos con numerosas personalidades de la vida política y cultural de España y otros países. No se limitó a formar parte y ser uno de los impulsores del llamado "grupo de Oviedo" (propiamente era el "animador" del grupo), sino que asumió, desde la corriente de pensamiento krausista, un verdadero papel de "intelectual orgánico" como impulsor de la reforma social y constitucional. Él interioriza la tradición liberal progresista y asume un ideario humanista con el cual enfrenta a la vida: El Ideal, entonces ya, o después, me incitó a la hipótesis de un mundo humano plácido, sereno, si no históricamente realizable, metafísicamente posible en tiempo y espacio indeterminados, en la medida en que la realidad empírica se tonifica por el ideal -el ideal, no meta-, inspiración y norma del hacer en la vida. La filosofía de Krause ofrecía un criterio ético para la conducta de la persona individual -el yo actual concreto- y mediante la persona individual, en las esferas comprensibles o integrables en una Humanidad terrena que aspira a apoyarse, no a descansar, en el regazo divino. Un "criterio" para estudiar la realidad social en movimiento. De él -y a través de Francisco Giner de los Ríos, referente innegable de varias generaciones de intelectuales- recibirá el organicismo jurídico, y la idea de lo justo (gerecht) como lo que realiza la idea del Derecho en cuanto unidad orgánica y la comprensión de la función del Derecho como instancia de realización de un ideal de justicia. Es aquí la comprensión la forma específica de conocimiento de algo que refleja una conformación finalista humana de la realidad. Aportaba, pues, un giro ético con su énfasis sobre la responsabilidad moral respecto a la dignidad de los otros. Se ha podido hablar, al respecto, de "un iusnaturalismo comprometido", en el intento de establecer una fundamentación sintética y material del Derecho que supere la argumentación formalista. También en consonancia ahora con el pensamiento de Azcárate, afirmaría el "carácter ético de la política". Precisamente uno de los rasgos caracterizadores de la crisis del Derecho político es la creciente tendencia del Estado a dominar, a someter al Derecho, "que, por otra parte, se descompone, desvaneciéndose su alcance ético, para convertirse en expresión de fuerza". 
Como otros krausistas, Adolfo Posada perteneció al "Partido Centralista" (creado en 1890) de orientación liberal progresista y evolucionista (En el Programa del Partico Centralista, 20 de junio de 1891, se mantenía un claro ideario republicano y krausista). El Directorio estaba formado por Salmerón y dos de sus seguidores, Cervera y Melgarejo, junto con otros tres parlamentarios -Pedregal, Azcárate (1840-1917) y Labra-. Formando parte de su Junta Nacional, junto con Salmerón, Azcárate (discípulo de Sanz del Río y afiliado al progresismo, en particular perteneció al bloque republicano que dirigía Ruiz Zorrilla), Odón de Buen, los hermanos Calderón, los hermanos González Serrano, los Machado (padre e hijo), Rafael María de Labra, Salas y Ferré, J.M.Piernas Hurtado, R.Becerro de Bengoa, Antonio Zozaya, entre otros. Su creación se inscribe dentro de un contexto caracterizado por el fracaso de las uniones republicanas (1887-1906). La importancia en el espectro político del Partido Centralista no parece que fuese mucha, pese a que contaba con cierto número de parlamentarios. Dicho Partido -integrado por intelectuales- pretendía el establecimiento de la República por procedimientos pacíficos y a través de elecciones democráticas: "la democracia -decía Azcárate- no proclama la revolución como procedimiento constante, necesario y siempre legítimo para llevar a cabo las reformas, sino tan sólo como un medio de defensa, como un medio de recabar para un país el derecho a regirse por sí propio". Su propuesta es la propia de un liberalismo "progresista" que apuesta por el régimen parlamentario sin corruptelas. En el Partido Centralista cristalizaba inicialmente el institucionalismo de inspiración republicana. En él el krausismo liberal trató de plasmar su vocación de reforma social y político-jurídica, dando sentido a una manera de sentir y vivir la vida. Para Posada el krausismo es un ethos, una actitud integral ante la vida, es decir, un movimiento de renovación ética y pedagógica.

Por otra parte, dos décadas más tarde y tras la experiencia de la Unión Republicana (1903), mantuvo un actividad especialmente activa en el Partido Reformista (creado en 1912 desde la intelectualidad krausista que impregnaba a la clase media), de cuya Junta Nacional fue miembro desde su creación, junto con Azcárate, Galdós, Ortega y Gasset, Fernando de los Ríos, Luis de Zulueta, Francisco Rivera Pastor, Gustavo Pittaluga, Rafael María de Labra, Pedro Salinas, García Morente, y un nutrido elenco de personalidades del liberalismo democrático de la época. Este Partido Reformista estaba encabezado por Melquíadez Álvarez, proponía un programa de reforma política y de transformación del sistema de Derecho liberal en sistema de Derecho social que convenía especialmente al ideario propio de Posada, refractario a todo radicalismo. Su programa trataba de realizar la reforma política, social y educativa. De hecho Melquíadez Álvarez, en muchos aspectos, puede ser considerado como realizador del proyecto reformista que Posada había defendido durante largo tiempo antes. Posada sería Senador por el Partido Reformista entre 1921 y 1923 , aunque su actividad en ese cometido no fuese especialmente intensa, ya que se dedicó mayormente a las labores de su Cátedra de la Universidad Central. Labores de la cátedra que constituyó siempre el eje central de su vida, y aunque fue jubilado en el año 1931 como catedrático de la Universidad Central, mantuvo su vinculación universitaria al ser nombrado Decano de la Facultad de Derecho de dicha Universidad de Madrid hasta su destitución como Decano y presidente del Instituto Nacional de Previsión en el año 1936. También 
participó, aunque con poco éxito en sus propuestas, en el proceso de reforma constitucional de la República. Perteneció a la Comisión Jurídica Asesora, y todavía durante la II República mantuvo la presidencia del Consejo de Trabajo y en 1935 ocupó la presidencia del Instituto Nacional de Previsión. Posada fue un intelectual comprometido con su tiempo y mantuvo una extraordinaria coherencia entre su pensamiento y su actividad científica y de acción reformista.

Es de realzar que Adolfo Posada refleja en sí -y en la evolución de su vasta producción científica- un cambio en el modelo de jurista, un jurista no formalista que ve el Derecho en su continua vinculación con la realidad que formaliza. De ahí la adopción del "método realista" en el estudio de los problemas de relevancia jurídica y política, y el entendimiento del Derecho como un sistema abierto y dinámico en una sociedad en permanente transformación, por lo que su actitud no es ni conservadora ni formalista. De este modo la tarea del jurista no es sólo la de aplicar el Derecho vigente, sino también la de proponer nuevas reglas. Podría decir, con Gierke, que "la ciencia del Derecho se condenaría ella misma a la impotencia si callase en los momentos supremos y decisivos de la vida jurídica: puede poner límites y asistir al legislador, y no debe renunciar a ello". Existen distintos "modo de mirar", en comprensión explicativa, el pensamiento de Adolfo Posada, uno de ellos, y no precisamente el menos trascendente en su sistema, es el del reformismo jurídicosocial que impregna toda su obra y a cuya realización práctica_dedicó un largo esfuerzo y ocupó muchos años de su larga madurez. Él trató de conectar, de humanizar la política, concibiéndola como un modo de ser el hombre. El estudio del pensamiento de esta fuerte personalidad creadora permitirá comprender mejor no sólo el pasado histórico sino también el presente de nuestro Estado social y en particular de nuestro Derecho social.

Su tarea en la reforma social constituye un legado que ha sido recibido por las generaciones que le sucedieron. Posada, en coherencia con el krausismo, no creó propiamente "escuela", pero sí un espíritu de trabajo y estilo de pensar científicamente. Él mismo ha de reconocer la amplia estela de discípulos, desde el mismo Nicolás Pérez Serrano, que le sucediera en la Universidad, hasta una pléyade de juristas: "En mis relaciones con los alumnos seleccionáronse mis verdaderos discípulos y entre éstos, mis ayudantes. La mayoría de esos discípulos y ayudantes, de los que ahora recuerdo, llegaron a ocupar puestos destacados en organismos del Estado o en la empresa privada, entre otros: Ursicionio Álvarez, Francisco Ayala, Niceto Alcalá Zamora (hijo), Segismundo Royo Villanova, Suñer, Ignacio Herrero, Alberto Martín Artajo, Juan Uña, Manuel Pedregal, Gaspar Bayón Chacón, Leiva, Juan Lladó, Luis Usera...".

En su período de madurez Adolfo Posada trató de superar los límites de la concepción del Estado liberal krausista, a través de un liberalismo democrático social que partía del otorgamiento de un importante papel al Estado y a las "formaciones sociales" que vertebran la pluralidad existente en la sociedad ${ }^{6}$. Para él se había producido una ruptura en la evolución

\footnotetext{
${ }^{6}$ MONEREO PÉREZ, J.L.: La reforma social en España: Adolfo Posada, Madrid, Ministerio de Trabajo y Asuntos Sociales, 2003, espec., Capítulo I ("La teoría jurídico-social del Derecho y del Estado en el 
política: la actual evolución se caracteriza "por la crisis de agotamiento del viejo liberalismo formalista, de cepa individualista, con al advenimiento del que allá por los años 1905 y 1906 se llamó "nuevo liberalismo", no abstencionista, social, o que procuraba contenido social a la acción del Estado, y contenido económico y cultural a las libertades y derechos constitucionales: transformación de los derechos del hombre y del ciudadano ${ }^{7}$. Culminó este advenimiento del nuevo liberalismo, v.gr., en Inglaterra, con la política social de Lloyd George, y lo representaron entre nosotros Azcárate, Moret, Canalejas, Dato". De ello resulta que la transformación del liberalismo se manifestó como influjo impulsor en la crisis de crecimiento del constitucionalismo perezosamente constructivo, consecuencia, tal crisis de manera inmediata, en su momento, antes de la guerra, de las nuevas y apremiantes exigencias sociales que demandaban nuevas formas jurídicas. Para ello defendería una "misión positiva" y activa del Estado en el desenvolvimiento de la vida social (incluida la solución directa de la llamada "cuestión social", derivada de la complejidad de "lo social", cuya comprensión explicativa puede proporcionar la sociología). Adolfo Posada hace suya la reflexión de Jellinek, al realzar la idea de fin en el Estado contemporáneo. Lo que le permite destacar la consagración positiva en el Derecho constitucional de una verdadera transformación social del Derecho público en la dirección de un movimiento político-social que asigna al Estado funciones directas de garantía del bienestar a los ciudadanos. Con todo en respuesta político-jurídica al advenimiento del proletariado a la acción política en los grandes Estados, y la constitución del socialismo como fuerza de lucha ("resultado todo ello del surgir fatal de la clase obrera, masa que se diferencia orgánicamente como consecuencia del gran desarrollo del capitalismo y del industrialismo").

La vida intelectual y profesional de Posada se desarrolló en el marco del proceso de crisis del liberalismo y su difícil -y problemática- cristalización político-institucional en España. En la primera década del siglo veinte era evidente el agotamiento del liberalismo clásico doctrinario para responder a las exigencias de gobernabilidad del sistema político. La crisis del Estado liberal se funde con una política económica y social interesada y clasista y con una falta de confianza de los ciudadanos sobre el buen gobierno de la nación, pluralísticamente conformada. Se localiza históricamente la crisis del sistema político (19231936), con el advenimiento de la Dictadura y el posterior fin de la monarquía (28 de enero de 1930-14 de abril de 1931). Tras medio siglo de existencia, el régimen de 1876 (con una Constitución doctrinaria, o sea la de Cánovas) se encontraba en el límite de sus posibilidades. En 1923 se produce el pronunciamiento militar de Primo de Rivera, que es aceptado por parte de la Corona. Agotada la fase de Dictadura, el Rey renuncia al trono. Se rompe así el

pensamiento de Adolfo Posada"), págs. 31 y sigs., 174 y sigs. ("Los presupuestos de reforma desde el liberalismo político-social avanzado").

${ }^{7}$ Desde finales del siglo XIX y primer tercio del siglo XX, es un período en el que se reproduce el agotamiento de la ideología inspiradora del "viejo liberalismo" (liberalismo abstracto y doctrinario), el advenimiento político de las "tendencias socialistas" y un fuerte brote del "imperialismo agresivo". Con la guerra, la agravación de la crisis del Estado se produce merced a la explosión imperialista que la guerra significa. En este sentido, POSADA, A.: Teoría social y jurídica del Estado. El sindicalismo, edición y estudio preliminar, "Sindicalismo reformista integrado y Estado democrático en el republicanismo social de Adolfo Posada” (pp. IX-LXIV.), al cuidado de J.L. Monereo Pérez, Granada, Comares (Col. Crítica del Derecho), 2018, págs. 20-22. 
limitado sistema político, de manera que "los conflictos que hasta entonces pudieran ser resueltos desde posiciones de poder quedaron sometidos a los azares de la lucha política, planteando con excepcional agudeza la importancia de conquista, individual o coaligadamente, la mayoría parlamentaria. La violencia de los conflictos de intereses en la sociedad española encontró amplia oportunidad para manifestarse; y las partes enfrentadas no vacilaron en intentar, desde el primer momento, lanzarse a la conquista del poder. Las elecciones municipales de abril del 31 fueron, en definitiva, las únicas que los vencidos aceptaron, sin intentar modificar la situación mediante un golpe de fuerza, que sigue, al cabo de unos meses, a la correspondiente consulta electoral. A las elecciones para las Constituyentes corresponde el golpe de Sanjurjo de agosto de 1932; a las de noviembre del 33 , la revolución de octubre, y a las de febrero del 36, la guerra civil".

El nuevo liberalismo en la formulación de Posada sería un "superliberalismo", el cual no supondría la negación del liberalismo sino su revisión necesaria para afrontar la coyuntura de una Humanidad en crisis, descompuesta y "dolorida". De ahí que encontrara en la Sociedad de las Naciones el supuesto de un "medio ambiente" en el cual había comenzado a formarse el "espíritu nuevo", una nueva atmósfera en la construcción de un nuevo tipo de sociedad internacional basada en la justicia social. La creación de aquél organismo internacional adquiere en su concepción un lugar extraordinario, porque no sólo representa la construcción de un nuevo orden internacional y el intento de impedir la violencia de las guerras, sino que supone también la consolidación de una Sociedad de Naciones que realice lo que llama el "superliberalismo", y que vendría a ser la garantía suprema del liberalismo. Entiende que esto es lo que se consagra en la Parte XIII del Tratado de Versalles, al establecer los derechos fundamentales del trabajador: "Considerando -se dice- que la Sociedad de las Naciones tiene por objeto establecer la paz universal, y que esta paz no puede fundarse sino sobre la base de la justicia social..." ". Habla, pues de la necesidad de superar el viejo, "pero no agotado", liberalismo nacional, siendo superado por la nueva concepción superliberal del régimen de las naciones. Este es el superliberalismo o "liberalismo superado", es decir, el ideal sublimado del puro liberalismo, conseguido a lo sumo antes del advenimiento de la guerra, de fronteras adentro en los Estados de más alta civilización. Ahora bien, Posada establece un vínculo estrecho entre el superliberalismo político y lo que también denomina superliberalismo social: para él bien se podría considerar que la Parte XIII, relativa al "Trabajo", del Tratado de Versalles, hace realidad el superlibealismo como realidad constitucional -y en cierto modo, jurídica- en el mundo del trabajo-; una realidad, en su momento inicial, pero en proceso de desarrollo, y que, además, demuestra que lo que llamamos "superliberalismo", no es un mero entretenimiento ideológico. Este liberalismo social opera una verdadera ruptura con el liberalismo clásico individualista y de democracia restringida propia del que Estado de Derecho Liberal ${ }^{8}$.

\footnotetext{
8 Expresamente, MONEREO PÉREZ, J.L.: La reforma social en España: Adolfo Posada, Madrid, Ministerio de Trabajo y Asuntos Sociales, 2003, espec., Cap. II (Crisis del Estado de Derecho Liberal y reforma constitucional: El reformismo social como alternativa a la crisis del Estado de Derecho Liberal"), págs. 133 y sigs.
} 
También participaría de modo activo en la crítica sin fisuras a la Dictadura de Primo de Rivera, y apoyaría la instauración de la II ${ }^{\mathrm{a}}$ República Española, aunque en sus Fragmentos de mis memorias, dejase traslucir un sentido o fuerte desencanto respecto al curso de la vida política y a la emergencia de la violencia. También había algo de resentimiento por la relegación de sus posiciones armonicistas en la Constitución Republicana de 1931 y las reformas emprendidas durante el breve período republicano. Su desencanto enlazaba con la conciencia del fracaso de su proyecto reformista, en términos análogos al que había auspiciado el partido reformista de Melquíades Álvarez -en gran medida artífice material de gran parte del programa reformista que en el plano doctrinal había venido defendiendo Adolfo Posada- antes del advenimiento de la Dictadura de Primo de Rivera. El problema es si Melquíades Álvarez tuvo el talento intelectual y práctico necesario para idear y llevar a cabo un nuevo sistema político.

El suyo era un humanismo idealista propio de los "democráticas de cátedra" del krausismo. Ese entendimiento del liberalismo desemboca en el reformismo social a cargo del Estado, reconociendo la necesidad "de una acción social en forma de tutela protectora". Hasta aproximarse fuertemente a las posiciones del "socialismo de Estado": apreciándose un movimiento de reforma político-social que mantiene el sentido reformista de una progresiva política social, o sea, de un socialismo sin la dogmática socialista y sin el sentido que supone la lucha de clases aplicada como método transformador o revolucionario: un nuevo liberalismo. Su propuesta reside en la creación de un "Estado tutelar" neutral respecto a las clases sociales pero fuertemente comprometido en la garantía de la libertad y de la justicia social. Por ello ha de ser un Estado intervencionista, un Estado social y jurídico (Estado Social de Derecho). Para Posada, la el intervencionismo público en la vida social y económica a través de la legislación social no supone en sí un cambio de modelo de sociedad, ni un camino hacia la socialización en un sentido socialista, sino una revisión de los esquemas liberales de organización del capitalismo por un tipo de capitalismo organizado o intervenido. Se puede decir que el intervencionismo se muestra como una solución transaccional entre las utopías socialistas y el optimismo individualista, igualmente peligroso, a nuestro parecer, para el orden social. Es de significar que esta revisión del liberalismo exige una reforma propiamente constitucional: una reforma de la constitución jurídica de la sociedad y del Estado, lo que presupone un reclamo de la fuerza conformadora del texto constitucional.

Él proclama la reforma legislativa social como una opción intermedia en la lucha entre los partidarios del statu quo individualista y los partidarios de una revolución. Se inscribe en el movimiento sociopolítico que adopta una reforma jurídico social gradualista en su ejecución y participada en su elaboración y aplicación práctica. Ello define el modelo de reformismo jurídico-social propuesto ya en el Proyecto de Instituto del Trabajo ${ }^{9}$ y que después se

\footnotetext{
${ }^{9}$ BUYLLA, A., POSADA, A. Y MOROTE, L.: El Instituto del trabajo: datos para la historia de la reforma social en España, Discurso preliminar de José Canalejas y Méndez; Memoria acerca de los institutos del trabajo en el extranjero, por J. Uña y Sarthou; prólogo a esta edición por Santiago Castillo, Madrid, Centro de Publicaciones Ministerio de Trabajo y Seguridad Social, 1986.
} 
respetaría, en lo esencial y en esto último, en el Instituto de Reformas Sociales (IRS) ${ }^{10}$, en el cual Adolfo Posada tendría una participación que, sin duda, puede calificarse de decisiva. Cien años después, puede apreciarse la centralidad del IRS, como protagonista institucional en un reformismo democrático-social que tuvo una función esencial en la reforma del Estado liberal de Derecho en crisis.

El esfuerzo reformista encontró un fruto indirecto cuando el Gobierno conservador de Francisco Silvela retomó la idea de un Instituto para organizar la operación reformista, creando por Ley de 23 de abril de 1903 el Instituto de Reformas Sociales, el cual aprovecharía la experiencia alcanzada con el Proyecto del Instituto de Trabajo. Este IRS fue mantenido por el Primer Gobierno de Maura, que había sustituido al de Silvela. Este Gobierno es el que encomendó la presidencia del IRS a G. de Azcárate y nombró a Posada y a Buylla en el año 1904 en puestos técnicos de destacadísima responsabilidad. Desde abril de 1904 Posada se mantuvo en el Instituto en su calidad de Jefe de la Sección Segunda (encargada de la Legislación e Información bibliográfica, Jurisprudencia, Redacción y Publicaciones) hasta su desaparición en 1924 (ya muy mermado durante la Dictadura de Primo de Rivera y el progresivo desplazamiento de sus funciones -dentro de la lógica del "Estado totalitario"- hacia órganos creados dentro de la estructura administrativa intervencionista del Ministerio de Trabajo). Desde su marcha a Madrid hasta su muerte ya no volvería a residir en Oviedo. Con una intensidad excepcional Posada mantuvo al máximo nivel su Sección realizando una labor fundamental en la preparación, e incluso redacción directa, de proyectos de legislación social, aproximando nuestra retrasada legislación social en muchos aspectos a de los países más avanzados del período.

El 30 de abril de 1903 se publica en La Gaceta de Madrid el Real Decreto de constitución del Instituto de Reformas Sociales. Su lógica interna era la propia del "liberalismo avanzado" -que no era otro, en el fondo, que el "liberalismo social" defendido por José Canalejas-; un viraje hacia el liberalismo social e intervencionista que sería el resultado de un largo proceso de maduración del pensamiento político jurídico sobre el apreciable fracaso del liberalismo clásico. Dicho Instituto se inspiraba en el Proyecto de Instituto de Trabajo, pero presentaba importantes diferencias. Por lo pronto su creación suponía la disolución de la CRS, estableciendo que la documentación y los libros de aquélla pasarían al Instituto. En abril de 1904, Buylla y Posada recibieron un telegrama firmado por Moret con la invitación de que formaran parte de la estructura directiva del mismo. Posada aceptó -sus dudas internas- fue nombrado, en su calidad de sociólogo y profesor de Derecho político, jefe de la Sección Primera, encargada de los servicios de biblioteca, de información bibliográfica, de jurisprudencia, y de redacción y publicaciones. Desde este ámbito -y en permanente contacto con la realidad social y con los actores implicados- pudo continuar ejerciendo su compromiso intelectual respecto al problema social y su reforma, buscando la armonía social desde la mejora de la condición de los trabajadores con el pleno disfrute de sus derechos de ciudadanía y frente al liberalismo doctrinario. Ello desemboca en la consagración

\footnotetext{
${ }^{10}$ MONEREO PÉREZ, J.L.: La reforma social en España: Adolfo Posada, Madrid, Ministerio de Trabajo y Asuntos Sociales, 2003, espec., Cap. II.2.2, págs. 281-356, y la bibliografía allí citada.
} 
constitucional de un verdadero Estatuto de los derechos de la ciudadanía, configurador de un status positivus de los pertenecientes a la clase trabajadora, en los planos civil, socioeconómico, y político-jurídico. Lo cual supondría la superación del individualismo liberal. El IRS fue presidido por Gumersindo de Azcárate, liberal republicano (de cuyo ideario no se apartó nunca, a pesar de que admitiera -junto con su maestro Azcárate- la "accidentalidad" de las formas de gobierno) vinculado a la Institución Libre de Enseñanza.

\section{La concepción organicista del Estado y el republicanismo social de Adolfo Posada}

La concepción organicista del Estado va unida ya en Posada, como en general en el pensamiento krausista (en su "actitud mental y ética", como destacaría Posada) ${ }^{11}$, a la concepción de la persona individual y social ${ }^{12}$. Para el krausismo la persona social es la unión de individuos que realizan por su cooperación orgánica una vida en común ${ }^{13}$. Pero para Posada -como en general para el krausismo- la persona individual no está aislada, sino situada en una comunidad y dentro de ella en colectividades y grupos sociales, como resultado de la cooperación social y orgánica de los individuos ${ }^{14}$. A través de la persona social, como agregación estrecha de hombres, la persona individual desarrolla su personalidad. La persona social constituye una unidad vital real reflejada en la agrupación de individuos. Por consiguiente, para él, como para Gierke, las asociaciones no son una individualidad artificial, ya que se corresponden con un sustrato real ${ }^{15}$. Las asociaciones tienen un substrato real constituido por las personas que la integran y sus relaciones y por

11 Para un estudio completo del pensamiento y la influencia de Adolfo Posada puede consultarse MONEREO PÉREZ, J.L.: La reforma social en España: Adolfo Posada, Madrid, Ministerio de Trabajo y Asuntos Sociales, 2003, 515 páginas; LAPORTA, F.J.: Adolfo Posada: política y sociología en la crisis del liberalismo español, Madrid, Ed. Cuadernos para el Diálogo, 1974, 355 páginas.

${ }^{12}$ No se olvide que para Posada del ideario krausista es abierto y flexible. Entiende que "el Krausismo fue, por fin, un movimiento de renovación ética y de significación pedagógica, y que llegó a su hora, y por eso arraigó en el espíritu colectivo; un movimiento más que de escuela, de tendencia, o bien de escuela, si ésta no se traduce en la elaboración de una dogmática construida, o de unos cánones, y se limita a ser una común orientación de pensamiento, y una manera de considerar los problemas del pensar y del vivir. El krausismo, sobre todo de Giner, que formará su espíritu abriéndolo a los cuatro vientos era más que nada una actitud mental y ética: aquélla, la mental, de austeridad, de reserva y de calurosa simpatía hacia todo esfuerzo sincero en los campos de la ciencia, y ésta, de austeridad también, de serena estimación de la vida, que debe ser en todo momento expresión práctica de un ideal...". Cfr. POSADA,A.: España en crisis, Madrid, 1923, págs.173-174.

${ }^{13}$ Véase GINER DE LOS RÍOS,F.: Principios de Derecho natural, en Obras Completas, t.I, Madrid, La Lectura, 1916, págs.46-47.; Id.: La persona social, t.I, en Obras completas, t.VIII, Madrid, 1923 (Reedición, La persona social. Estudios y fragmentos, edición y estudio preliminar, "El organicismo social de Giner de los Ríos” (pp. IX-XXXIX), a cargo de J.L. Monereo Pérez, Granada, Ed. Comares (Col. Crítica del Derecho), 2008).

${ }^{14}$ Para la noción krausista de personalidad social, asumida por Adolfo Posada, véase GINER,F.: La persona social, t.I, en Obras completas, t.VIII, Madrid, 1923. Gierke ya había planteado que el hombre tiene dos modos de existencia, como individuo y como miembro de las asociaciones en que realiza sus fines, ninguno de los cuales puede ser eliminado sin negar la esencia misma del hombre. Véase, al respecto, GONZÁLEZ VICEN,F.: "La teoría del Derecho y el problema del método jurídico en Otto von Gierke", en Estudios de Filosofía del Derecho, Santa Cruz de Tenerife, Facultad de Derecho-Universidad de la Laguna, 1979, pág.267.

15 GIERKE, O.V.: La función del Derecho Privado y otros estudios, trad. José M. Navarro de Palencia, revisión, edición y estudio preliminar, "La teoría jurídica y social de Otto von Gierke: teoría del Derecho Social y de las personas colectivas" (pp.IX-LXI), Granada, Ed. Comares, 2015. 
los órganos que sirven a la realización de sus fines. Hasta tal punto son entidades reales que el Derecho no las crea propiamente sino que las recibe como ya existentes en la realidad histórico-social ${ }^{16}$.

Lo cual es predicable respecto al Estado como persona jurídica que coopera e impulsa a los individuos para la realización de los fines que le son propios. Es así coherente con su concepción jurídica su decidido apoyo a la intervención promocional del Estado en la solución de los problemas sociales y económicos. Aquí nuevamente confluirán pensamiento y acción, especialmente -no únicamente, porque Posada ya se había interesado desde siempre por la "cuestión social" y sus cauces de solución propiamente jurídica y política mediante una reforma del Estado liberal- desde su incorporación al Instituto de Reformas Sociales participando en los debates sobre el tratamiento político-jurídico de la cuestión social y en la redacción directa de los proyectos de intervención legislativa en la materia.

La teoría de la sociedad y del Estado de Posada es esencialmente organicista, donde la sociedad es organismo vivo que genera en su interior diversos modos de organización colectiva capaces de crear su propio Derecho. Desde este modo de pensar, la sociedad es considerada como un "ser real" y no como una simple agregación de individuos. La naturaleza es un todo orgánico en el cual el hombre está plenamente inmerso. Las instituciones jurídicas tienen una base esencialmente orgánico-sociológica. Pero aquí el organicismo krausista de se dota de una base esencialmente positivista, en la línea que el propio Posada llamara "krausopositivismo". Este método positivo se cimenta en él a través de su importante aportación a la sociología, que le hace comprender el desarrollo social como un proceso de transformación permanente de la estructura social en virtud de la función social ${ }^{17}$, lo que supone una superación de la concepción metafísica de la sociedad ${ }^{18}$. Lo que, por cierto, no le llevó a defender la sustitución de la ciencia jurídica por la sociología jurídica. Él insertó la perspectiva sociológica en la ciencia política sin incurrir en la desviación de sociologismo en la teoría política, lo cual quiso ser una elemento de renovación en el plano de la metodología, de manera que pueda entenderse la política como una ciencia social del Estado, que requiere de un conocimiento directo y objetivable de la

\footnotetext{
${ }^{16}$ Para esa concepción también en Gierke, GONZÁLEZ VICEN,F.: "La teoría del Derecho y el problema del método jurídico en Otto von Gierke", en Estudios de Filosofía del Derecho, Santa Cruz de Tenerife, Facultad de Derecho-Universidad de la Laguna, 1979, pág.271.

${ }^{17}$ Adviértase el papel esencial en la elaboración de esta idea de Leon Duguit, el cual había, entre otras cosas, teorizado sobre la propiedad como mera función social. Véase DUGUIT,L.: Las transformaciones generales del Derecho privado desde el Código de Napoleón, trad. Carlos G.Posada, de la $2^{\mathrm{a}}$ ed., francesa, Madrid, s.f., págs.167 y sigs. (Reedición y revisión de la traducción, con estudio preliminar, "Objetivismo jurídico y teoría de los derechos en León Duguit” (pp. XI-XXXIX) a cargo de J.L. Monereo Pérez y J. Calvo González: DUGUIT, L.: Las transformaciones del Derecho público y privado, edición crítica de tres monografías de Leon Duguit vinculadas por la idea-fuerza de las transformaciones del Derecho Público y Privado y el por entonces emergente (en estado naciente) Derecho Social Granada, Ed. Comares (Col. Crítica del Derecho), 2007).

${ }^{18}$ Véase POSADA,A.: Principios de Sociología, Madrid, Daniel Jorro, Biblioteca Científico-filosófica, $1^{\text {a }}$ ed., 1908, $2 \square$ ed., 1929. Sobre este aspecto, véase GIL CREMADES,J.J.: El reformismo español. Krausismo, escuela histórica, neotomismo, Barcelona, Eds. Ariel, 1969, pág.284. Sobre el krausopositivismo, puede consultarse JIMÉNEZ GARCÍA, A.: El krausopositivismo de Urbano González Serrano, Departamento de Publicaciones de la Excma Diputación Provincial de Badajoz, 1996, págs. 125 y sigs.
} 
sociedad $^{19}$. Ese organicismo krausista contiene una filosofía social a la que subyace una concepción de la justicia social. Esa perspectiva liberal-organicista se aprecia perfectamente en la idea de la sociedad percibida como organicismo social (el carácter orgánico de la sociedad; de la cual emana un "fluido ético" que se materializa en normas y pautas de conducta jurídicas), que, sin embargo, presupone una concepción pluralista de la sociedad ${ }^{20}$.

Esta pretensión "engance" entre las diversas disciplinas que se estudian los fenómenos sociales desde puntos de vista distintos pero complementarios e integradores se refleja en el hecho de que Adolfo Posada, con el apoyo del editor José Lázaro Galdiano, crease y dirigiese la Revista de Derecho y Sociología (se publicarían seis números, de enero a junio de 1895) y su misma participación activa en revistas con crónicas y ensayos de sociología y ciencia política (La España Moderna ${ }^{21}$; La Nueva Ciencia Jurídica; Revista General de Legislación y Jurisprudencia; BIL, etc. ${ }^{22}$. Todas estas publicaciones se constituían en verdaderas plataformas públicas de las ideas renovadoras, reformistas y positivistas.

Esta concepción de la interpenetración de los saberes y la ideología organicista se vinculan en el krausismo político social con el intento de superación del liberalismo individualista por el republicanismo social o "liberalismo social"23. La comprensión sociológica de la política se llevaría a cabo bajo la visión utilitaria de servir de base sólida para una democratización

\footnotetext{
${ }^{19}$ En este sentido, véase POSADA,A.: "Sobre la idea sociológica del Estado", en BILE, XXIII, 1899; "El problema del origen del Estado", en BILE, XVI, 1892; "Teorías modernas acerca del origen de la familia, de la sociedad y del Estado", en RGLJ, 80/1, 1892; "La base sociológica de la política", en BILE, XXXIV, 1910. También su comentario a la obra de Vaccaro,A. Les bases sociologiques du droit et de l'Etat (París, Gard. et Birière, 1898), en La España Moderna, núm.116 (1898).

${ }^{20}$ Ampliamente, MONEREO PÉREZ, J.L.: El reformismo socio-liberal de Giner de los Ríos: organicismo y corporativismo social, en Revista española de Derecho del Trabajo. Civitas, núm. 142 (2009), págs. 279338. Y el libro fundamental de GINER DE LOS RÍOS, F.: La persona social. Estudios y fragmentos, edición y Estudio preliminar, "El organicismo social de Giner de los Ríos" (pp. IX-XXXIX), a cargo de J.L. Monereo Pérez, Granada, Ed. Comares (Col. Crítica del Derecho), 2008, espec., págs. 109 y sigs. y 137 y sigs.

21 "La España Moderna" (1889-1914) fue una de las revistas culturales más importantes del período. Fue sostenida económicamente por José Lázaro Galdeano. El modelo de la publicación de Lázaro fue la francesa La Revue des Deux Mondes. Pero los objetivos de La España Moderna eran más ambiciosos, ya que anexo a la revista una importante colección de libros, constituyendo el esfuerzo traductor más importante del período. Véase MAINER,J.C.: La edad de plata (1902-1939). Ensayo de interpretación de un proceso cultural, Madrid, Ediciones Cátedra, 1983, pág.65.

${ }^{22}$ Sobre el proyecto de "La España Moderna", véase ASÚN,R.: "El Europeísmo de "La España Moderna"", en TUÑON DE LARA,M. y otros.: La España de la Restauración. Política, economía, legislación y cultura, Madrid, Siglo XXI editores, 1985, págs.469 y sigs. La España Moderna tuvo un papel fundamental en el desarrollo de los estudios jurídicos. Se publicaron todos los manuales europeos más relevantes, con la colaboración de sobre todo de la doctrina de inspiración krausista. En ella se publicaron obras de Giddings, Ihering, Hunter, Gumplowicz, Goodnow, Ricci, Summer Maine, Sighele, Martens, Mommsen, Lombroso, Ferri, Fioretti, Tardé, Carnevale, Bryce, Garófalo, Caro, Champcomunale, Buysson, Burguess, etcétera. Ello permitió la difusión de aquellas doctrinas que se consideraban más útiles para la transformación y regeneración de nuestro país en un sentido análogo a los procesos de cambio que se estaban produciendo en los países europeos más avanzados.

${ }^{23}$ Un republicanismo o liberalismo social que entronca con el liberalismo revisionista (social-liberal) de la filosofía política anglosajona en la tradición intelectual de J. Stuart Mill, T. Green y L.T. Hobhouse. Véase MONEREO PÉREZ, J.L.: "Los fundamentos del "liberalismo social” y sus límites: Leonard Trelawney Hobbouse", estudio preliminar a HOBBOUSE, L.T.: Liberalismo, trad. Julio Calvo Alfaro, Granada, Ed. Comares, 2007, págs. VII-LIV.
} 
en la vida política y una reforma social que afrontara el gravísimo problema de la "cuestión social" entre los dos siglos: su idea es mejora la constitución de la sociedad, de manera que los estudios de la sociedad y del Estado serían un eslabón previo para llegar a su reforma sustancial $^{24}$. Él hablaba, con Ortega y Gasset, de "un peculiar cambio histórico" 25 . En este cuadro de renovación del liberalismo, el krausismo positivista pudo defender un organicismo compatible con la autonomía real del individuo ${ }^{26}$ y con un régimen democrático. El republicanismo social reformista e intervencionista de Posada es sin duda un liberalismo democrático, incluso cuando defendió la "democracia orgánica" en el cuadro de una reforma de las instituciones políticas liberales, como se analizará más adelante ${ }^{27}$. Adolfo Posada defiende una "democracia orgánica" liberal y pluralista, basada en el respecto de los derechos políticos, civiles, económicos, sociales y culturales de una ciudadanía plena ${ }^{28}$. Esa idea de democracia orgánica enlaza directamente con la singular teoría organicista del Estado y la reforma del sistema parlamentario desde el liberalismo político-social asumidas por Adolfo Posada ${ }^{29}$. Por ello no puede aceptarse cualquier identificación entre organicismo krausista y organicismo autoritario: basta reparar en la orientación del Estado totalitario -y la ideología que le subyace- hacia el triunfo del "hombre exterior" reducido a pura masa amorfa y manipulable desde el poder, escindiéndolo y relegando al "hombre interior", cuando, precisamente, en el pensamiento del Posada krausista siempre se realzó la pervivencia del "hombre interior" y el hecho de que toda reforma auténtica debería suponer la educación y autorreflexividad de la persona individual. Su "idea pura del Estado" se basa

\footnotetext{
${ }^{24}$ Por ello aprecia en la sociología un valor práctico, un alcance político; en su suma, una orientación para la vida. Cfr. POSADA,A.: "Comentario al libro de G.L.Duprat, Science sociale et democratie” (París, 1900), en La España Moderna, núm.138 (1900); "La sociología de Ward", en BILE, XXX. Sobre la vinculación de la sociología y, en general, de sus estudios científicos hacia la solución práctica de los problemas políticos y sociales de nuestro país se hablará más adelante.

${ }^{25}$ POSADA,A.: La crisis del Estado y el Derecho Político, Madrid, C.Bermejo, 1934, Lección 9a ("La readaptación social de las Constituciones Política. Soberanía y servicio público"), págs.129 y sigs., en particular pág. 130.

${ }^{26}$ Esa defensa del individuo es predicable de la filosofía social del krausismo en la cosmovisión de Giner. En este sentido GIL CREMADES,J.J.: "El pensamiento jurídico español del siglo XIX: Francisco Giner de los Ríos, en Anales de la cátedra Francisco Suárez, Universidad de Granada, núm.11, fascículo 2 (1971), pág.50.

${ }^{27} \mathrm{El}$ krausismo presentaba cierta inclinación hacia el carácter orgánico de la democracia, lo que en general no debe inducir a peNsar que se identifique con una ideología reaccionaria de tipo totalitaria o pre-fascista. Autores como Sales y Ferré, adoptarían también ese enfoque orgánico de la democracia, y que se correspondía con el organicismo krausopositivista que se reflejaba en su sociología. Véase NUÑEZ ENCABO,M.: Manuel Sales y Ferré: Los orígenes de la sociología en España, Madrid, Ed.Cuadernos Para el Diálogo, 1976, pág.245, y 248 y sigs.

${ }^{28}$ MONEREO PÉREZ, J.L.: La reforma social en España: Adolfo Posada, Madrid, Ministerio de Trabajo y Asuntos Sociales, 2003, espec., págs. 176 y sigs. ("Revisión de la Constitución política en el sentido de la implantación de un sistema democrático"), y 477 y sigs. ("El Derecho como técnica específica de integración social: los derechos sociales de ciudadanía en el pensamiento de Adolfo Posada y su función en la Constitución Social). Adolfo Posada defiende un republicanismo de los derechos y libertades fundamentales en el marco de una democracia constitucional basada en el pluralismo político y social, y contando, por tanto, con la participación activa de los ciudadanos y de los grupos y organizaciones sociales de intereses comunes solidarios donde se desarrolla su personalidad integral y se posibilidad su autorrealización (democracia pluralista, funcional y social).

${ }^{29}$ Ampliamente, MONEREO PÉREZ, J.L.: La reforma social en España: Adolfo Posada, Madrid, Ministerio de Trabajo y Asuntos Sociales, 2003, págs. 104 y sigs., y 174 y sigs.
} 
en la concepción del hombre-persona inserta en un orden social ${ }^{30}$. Para Posada el pueblo tiene una propia entidad al ser un "organismo social vivo"31. Lo que postula Posada es un organicismo espiritualista y evolucionista de raíz krausista, pero no biologista ${ }^{32}$. En Posada la sociedad no es concebida como un organismo meramente fisiológico ${ }^{33}$. Él no era determinista, y se resistía a toda suerte de fatalismo; creía que los seres humanos hacen su historia. Lo social tiene una especificidad no natural, pensaba en términos de "desnaturalización" de lo social, y todas las "cuestiones sociales".

Es un "liberalismo orgánico"34 de inspiración krausista y de orientación social, basado en la idea de que la sociedad es un organismo social de dimensión espiritual y finalista, y en la asunción por el Estado democrático de un papel intervencionista y protector de las clases más débiles de la sociedad. Lo cual le permite evitar el doctrinarismo caracterizador del primer liberalismo y defender tendencias conciliadoras o posiciones intermedias entre distintas doctrinas. Ese liberalismo no es ni individualista ni socialista, sino de carácter éticoespiritual y realista ${ }^{35}$. Ese liberalismo orgánico (muy influido por la escuela germanista del Derecho público) intenta acudir a la historia propia con la finalidad de vincularla a un proyecto constitucional que alcance la correspondencia del Estado político con la

${ }^{30}$ POSADA,A.: La idea pura del Estado, Prólogo de Nicolás Pérez Serrano, Madrid, Edersa, 1944.

${ }^{31}$ POSADA,A.: La idea pura del Estado, cit.,págs.76-77; POSADA, A.: Woodrow Wilson y su obra El Estado, Madrid, Librería General de Victoriano Suárez, 1921, págs. XV y sigs.; POSADA,A.: Teoría social y jurídica del Estado, cit., pág.84. En esa idea de organismo social queda de manifiesto cierta influencia de la tendencia psicologista de Spencer. Véase SPENCER, H.: Los primeros principios, edición y estudio preliminar, "La ideología del darwinismo social y la filosofía social de Spencer" (pp.VII-XXXIV), a cargo de J.L. Monereo Pérez, Granada, Ed. Comares (Col. Crítica del Derecho), 2009, págs. 185 y sigs.

De cualquier modo esa idea de una sustancia natural del pueblo mantiene puntos de contacto con las concepciones de extracción diferente de Carl Schmitt, pero entroncan quizás más significativamente con el filón del historicismo de Otto von Gierke. Puede verse, al respecto, GONZÁLEZ VICEN,F.: "La teoría del Derecho y el problema del método jurídico en Otto Von Gierke", en Estudios de Filsofía del Derecho, Tenerife, Universidad de La Laguna, 1979, págs.259 y sigs. Para Schmitt, puede consultarse SCHMITT,C.: El nomos de la tierra, edición y estudio preliminar., "Soberanía y orden internacional en Carl Schmitt" (pp. IX-CXXVIII), a cargo de J.L.Monereo Pérez, 2003; y sobre su pensamiento contextualizado en su época, ampliamente, MONEREO PÉREZ, J.L.: Espacio de lo político y orden internacional. La teoría política de Carl Schmitt, Barcelona, Ediciones de Intervención Cultural/El Viejo Topo, 2015.

${ }^{32}$ GINER DE LOS RÍOS,F.: Persona social. Estudios y fragmentos, Madrid, Librería General de Victoriano Suárez, 1899, págs.46 y sigs. (Reeditada, con estudio preliminar de J.L. Monereo Pérez, Granada, E. Comares, 2008), donde afirma, por otra parte, que la historia del pensamiento humano no es un erial de contradicciones insolubles, sino una evolución, un proceso constructivo, por más aparente que sea en ocasiones y en la superficie la anarquía conviene bosquejar el sistema de esa evolución, sus factores cardinales y los elementos por cada uno de ellos aportados a la incesante génesis de este concepto (Ibid.,págs.46-47); y la crítica a H.Spencer, págs.68 a 74. Veáse GONZÁLEZ SEARA,L.: La sociología, aventura dialéctica, Madrid, Tecnos, 1971, págs.62 a 64.

${ }^{33}$ Explícitamente, POSADA,A.: Tratado de Derecho Político, edición íntegra en un sólo volumen y Estudio preliminar, "El pensamiento político-jurídico de Adolfo Posada" (pp. VII-CLXIII), a cargo de J.L.Monereo Pérez, Granada, Ed.Comares (Colección Crítica del Derecho), 2003, págs.215-216.

${ }^{34}$ Esta es la calificación de los liberales inspirados por Krause, realizada por LEGAZ LACAMBRA,L.: "El pensamiento social de Gurmersindo de Azcárate", en Estudios de historia social de España, 4 vols., vol.1º, Madrid, CIS, 1960, pág.28, donde observa que "El liberalismo orgánico ha sido una realidad ideológica e intelectual tan auténtica como el liberalismo individualista y, por individualista, materialista. El carácter orgánico fue precisamente la característica de los liberales inspirados en la filosofía de Krause".

${ }^{35}$ DÍAZ,E.: Filosofía social del krausismo español, cit., págs.204-205, con referencia en este sentido a Legaz Lacambra. 
constitución "material" e histórica, no meramente formal ni abstracta, porque sólo así podría corporeizar a la vez las fuerzas sociales realmente existentes y las ideas históricas que impulsarían el progreso social. Su liberalismo era reformador, no revolucionario, buscaba un justo medio que no era el resultado de una solución política oportunista. Buscaba transformar al hombre interiormente (de ahí la función esencial de la enseñanza ${ }^{36}$ ), pero también transformar constructivamente el ambiente político-social y económico que lo condiciona en el libre desarrollo de su personalidad. Su apuesta es la del "republicanismo o liberalismo social-democrático", bien sea que desde el organicismo social subyacente en todo momento a su pensamiento. Su verdadero ideal sigue siendo la democracia liberal revestida de organicismo social.

Posada explicaba la tragedia política de su época como la falta de "fluido ético" en las clases dirigentes, que no han llegado a sentir lo que de ellas exige la realidad efectiva de un orden público. Pero ese organicismo liberal krausista desemboca en un "típico solidarismo social" ${ }^{37}$, que se aparta del organicismo naturalista de tipo biológico propio de los regímenes fascistas ${ }^{38}$ y que se inserta en el marco de la revisión democratizadora del Estado liberal de Derecho. No obstante, mantener el liberalismo orgánico vinculado a la tradición del romanticismo político ${ }^{39}$ a finales del primer tercio del siglo veinte (al estilo del pensar de Posada, como desde el socialismo organicista de Fernando de los Ríos y de Julián Besteiro) se prestaba inevitablemente a equívocos ${ }^{40}$, ya que desde posiciones de liberalismo

\footnotetext{
${ }^{36}$ Él aceptó de buen grado los consejos que en carta le formulara Francisco Giner para la orientación de fondo de su discurso de inauguración del año académico 1884-1885, intitulado La enseñanza del Derecho en las universidades. En su carta dirigida a Posada decía Giner, que la finalidad es formar españoles conscientes de su responsabilidad nacional, y que contribuyan al necesario cambio político y social de España. Cfr. GINER DE LOS RÍOS,F.: "Carta a don Adolfo Posada. Bases para una reforma Universitaria de hace ya medio siglo", en Ensayos y Cartas, México, Tezontle, 1965, págs.104-108, y "La reforma de la enseñanza del Derecho", en Obras Completas, vol.II, Madrid, 1916, págs.264-265. La obra de referencia que recoge el discurso aludido, POSADA,A.: La enseñanza del Derecho en las Universidades. Estado actual de la misma en España y proyectos de reformas, Madrid, Librería de Fernando Fé, 1889, desde la primera página orienta el ensayo dentro del movimiento reformista existente en toda Europa (Ibid., pág.1).

${ }^{37}$ LAPORTA,F.: Adolfo Posada, cit.,pág.111. El cual realza que al final de su vida reafirmaría el organicismo ético, "precisamente con la intención de hacerlo compatible con la libertad". Pero "Quizá esta insistencia en favor de la ética y la supervaloración de la metafísica signifiquen, al final de su vida, una huida, un refugio ante la problemática real del primer tercio del siglo XX. Quizá sea una puerta para qu el viejo liberal escape de un mundo que ya no comprende y que le amenaza" (Ibid.,pág.113).

${ }^{38}$ Explícitamente, POSADA, A.: Hacia un nuevo Derecho político, Madrid, Ed.Páez, 1931, págs.114-115, y, antes, contundentemente, en págs. 18 y sigs. La crítica al fascismo, en POSADA,A.: La crisis del Estado, cit., págs.86 y sigs.; La reforma constitucional, cit., pág. 134; "Fascismo... obliga”, en BILE, núm.58 (1934), págs.18 a 23. Una apreciación de conjunto sobre la crítica de Posada al fascismo, puede encontrarse nuevamente en la excelente obra de LAPORTA,F.: Adolfo Posada, cit.,págs.221 y sigs.

${ }^{39}$ Véase la obra de SCHMITT,C.: Romanticismo político, a cura di Carlo Galli, Milano, Giuffrè editores, 1981. Traducción al castellano, Romanticismo político, L.A. Rossi y S. Schwarzböck, rev. J. Dotti, Buenos Aires, Universidad Nacional de Quilmes Ediciones, 2001.

${ }^{40} \mathrm{Se}$ ha señalado, con razón, que "en el XIX todavía resulta posible conciliar -aunque no sin dificultadesorganicismo y liberalismo. Posteriormente, cada vez será más difícil semejante síntesis y las concepciones organicistas de la sociedad irán mostrándose decididamente totalitarias: de un posible "liberalismo de grupos" de carácter orgánico se pasa así después a una entificación totalitaria del organicismo jerárquicamente superior, que no será otro sino la nación". Cfr. DÍAZ,E.: Estado de Derecho y sociedad democrática, Madrid, Taurus, 1998, pág.73, y más precisamente la relación entre el organicismo social y el "Stato Etico" en la doctrina del fascismo italiano, Ibid., págs.68 y sigs.; HELLER, H.: Europa y el fascismo (1931), incluye el ensayo
} 
doctrinario y decididamente autoritario se mantenían también principios organicistas (v.gr., la defensa de una "democracia orgánica" y, más matizadamente, la propuesta de una segunda cámara profesional, la cual ciertamente formaba parte del "ambiente" de la época desde distintas corrientes ideológico-políticas y en el marco de la consiguiente ambigüedad respecto del significado político de su implantación). En los años veinte se había generalizado las ideología corporativista sobre la representación política, lo cual se reflejó tanto en los grandes tratadistas del Derecho político (Maurice Hauriou; León Duguit; Adolfo Posada; Ruiz del Castillo...) como en la élite política. Las doctrinas organicistas y antiindividualistas estaban siendo impulsadas por diversas corrientes -extranjeras e internasde pensamiento, en una coyuntura histórica caracterizada por la crisis del Estado liberal. Era la crisis específica del régimen parlamentario español, porque, como se hizo notar, "el régimen parlamentario, leal y sinceramente, no ha existido en España, y que las Cortes no han representado la voluntad de la Nación, sino la voluntad de los oligarcas"41. En esta tradición se partía de la defensa de un sindicalismo reformista integrado y de un corporativismo moderado compatible con los sistemas democráticos ${ }^{42}$.

Era la pseudodemocracia parlamentaria de la Restauración, aunque el ambiente crítico era más allá del hecho diferencial- más generalizaba en los países europeos del periodo ante la emergencia de la cuestión social y la extensión del sufragio universal y el "miedo" a sus consecuencias. Se había extendido ampliamente la idea que la forma de hacer más real eficaz y real la representación política era la presencia institucionalizada de los grupos sociales (económicos, profesionales, culturales...) como instancias que podían vertebrar a la sociedad heterogénea en las postrimerías del sistema liberal en crisis. Existía una crítica generalizada hacia el sistema de partidos políticos y su falta de autenticidad, lo que unidad a la proclividad hacia las concepciones unificadoras y no partidistas acaban por reforzar a los grupos más conservadoras de inspiración corporativista-organicista ${ }^{43}$. Pero la posición de Posada es explícitamente contraria al modelo organicista base del fascismo ${ }^{44}$, pretendía (y en esto

\footnotetext{
“¿Estado de Derecho o Dictadura?” (1929-1930), trad. de F.J. Conde, edición y estudio preliminar a cargo de J.L. Monereo Pérez, Granada, Ed. Comares (Col. Crítica del Derecho), 2004; NOLTE,E.: La crisis del sistema liberal y los movimientos fascistas, Barcelona, Ed.Península, 1971; ROSENBERG, A.: "El fascismo como movimiento de masas" (1941), en VV.AA.: Fascismo y capitalismo, selección a cargo de Wolfgang Abendroth, Barcelona, Ed. Martínez Roca, 1976. Sobre el pensamiento jurídico y político de Hermann Heller, consúltese MONEREO PÉREZ, J.L.: La defensa del Estado Social de Derecho. La teoría política de Hermann Heller, Barcelona, Ediciones de Intervención Cultural/El Viejo Topo, 2009, espec., págs. 19 y sigs., y Cap. 2, págs. 80 y sigs.

${ }^{41}$ ZANCADA,P.: Los problemas constitucionales de España, Madrid, Compañía Ibero-Americana de Publicaciones, 1930, págs.43-44.

${ }^{42}$ Sobre los distintos tipos de corporativismo históricos y simétricamente respecto a los diversos tipos de sindicalismo (revolucionario integral o extremista y reformista integrado, ambos en sus diversas manifestaciones y expresiones ideológicas, véase PARROT, J.PH.: La représentation des intérêts dans le mouvement des idées politiques, París, Presses Universitaires de France, 1974, espec., págs. 41 y sigs., y 98 y sigs. En otra perspectiva, VALLAURI, C.: Le radici del corporativismo, Mario Bulzoni Editore, Roma, Edizioni Bulzoni, 1971, espec., págs. 13 y sigs.

${ }^{43}$ Véase GARCÍA CANALES,M.: El problema constitucional en la Dictadura de Primo de Rivera, Madrid, CEC, 1980, cap.5, que recuerda que Melquíades Álvarez había advertido sobre la imputación de todos los males a los supuestos excesos de la democracia y del parlamentarismo (Ibid.,pág.401).

${ }^{44}$ POSADA,A.: Hacia un nuevo Derecho político, Madrid, Ed.Páez, 1931, págs.104 y sigs.
} 
influyó directamente en la propuesta de reforma del Senado realizada por el Partido reformista) incorporar al Estado, con participación en el Gobierno, a los intereses socialmente organizados, "iniciando así un avance hacia organización política de la democracia", no una alternativa a ésta ${ }^{45}$. En sus "Bases para la Constitución política de España"46 y en el Anteproyecto de la Comisión Jurídica Asesora de cual formara parte incluyo esa representación específica de intereses. Sin embargo, el debate se replantea en la Comisión de las Cortes, donde triunfa la Cámara única, rechazándose la propuesta de un Senado con base corporativa en representación social ${ }^{47}$. Pese a que para Posada un elemento fundamental de la nueva constitución de la democracia era un Senado que debería representar los intereses sociales organizados.

Según Posada, la sociedad contemporánea es pluralista, está constituida no sólo por individuos, sino también por fuerzas o formaciones sociales. La sociedad política comprende todas aquellas entidades colectivas que se constituyen por los hombres con verdadera personalidad real, consagrada por el Derecho, obedeciendo a los estímulos de solidaridad y a la necesidad de la lucha por la vida para realizar o defender fines comunes ${ }^{48}$. Su visión pluralista de la sociedad es obvia: por lo general -afirma- el Estado político es una sociedad de sociedades más o menos compleja ${ }^{49}$. Por ello las asociaciones -especialmente los

\footnotetext{
${ }^{45}$ Cfr.POSADA,A.: La reforma constitucional, cit., pág.3. Y señala, recordando su experiencia en el Senado como parte de la representación del Partido Reformista al que pertenecía: "En mi intervención en el Senado en 1921- procuré razonar la tesis de la reforma constitucional, al discutirse una enmienda que presenté al dictamen de contestación al discurso de la Corona, enmienda que, aun no siendo, como he dicho, libro de partido, conceptuó oportuno reproducir a continuación" (pág.3). Recoge la "Enmienda presentada al dictamen de contestación al discurso de la Corona" en el Senado Español (Ibid.,págs.4-5)

${ }^{46}$ Importa retener aquí que para Posada la Constitución política es la expresión jurídica del régimen del Estado con respecto a la organización de los poderes o instituciones fundamentales en las que encarna prácticamente el ejercicio de la soberanía, y a la limitación de la acción de esos poderes en sus relaciones con la personalidad con la personalidad humana. La Constitución se concibe así como sistema o régimen de garantías. En este sentido asume la finalidad de la Constitución política que se explicita en el art.16 de la "Declaración" francesa de 1789, cuando afirma que toda sociedad en la cual la garantía de derechos no está asegurada, ni la separación de poderes determinada, no tiene Constitución. Cfr. POSADA,A.: Tratado de Derecho político, t.II, $5^{\text {a }}$ ed., Madrid, Lib.General de Victoriano Suárez, 1935, págs.16 y sigs. Según él se podría definir la Constitución, desde el punto de vista político, como una aspiración a la estabilidad y a la continuidad formal del Estado, y desde el jurídico, como un régimen de ley en el Estado (Ibid.,pág.33).

${ }^{47}$ Véase el propio POSADA,A.: La nouvelle Constitution espagnole, París, 1932, págs.177 y sigs. La propuesta de una "Cámara sindical" venía de antiguo, y había sido defendida desde diversas direcciones de pensamiento, muy frecuentemente en las filas, "plurales" en sí, del krausismo especialmente predispuesto por su ideología organicistas y armonicista. Véase SANTAMARÍA DE PAREDES,V.: "El movimiento obrero contemporáneo", en Discursos de recepción y de contestación leídos ante la Real Academia de Ciencias Morales y Políticas al dar posesión de sus plazas a los individuos de número de la misma, 1891-1894, t.VI, Madrid, 1894, pág.476.

${ }^{48}$ Un contemporáneo suyo, Dorado Montero, haría referencia en la vida social a la lucha entre los diversos grupos e individuos, pero también a las exigencias de cooperación inherente a cualquier evolución de la vida social. Véase DORADO MONTERO,P.: "Función de las leyes y la autoridad en la evolución social", en Revista Política Iberoamericana, 1906, pág.70, cit.,por BLANCO RODRÍGUEZ,J.A.: El pensamiento sociopolítico de Dorado Montero, Salamanca, Centro de Estudios Salmantinos, 1982, págs.31 y sigs. Sin embargo, Posada no llegaría a aceptar la realidad histórica de la lucha de clases como motor del desenvolvimiento social, a diferencia de Dorado Montero en relación con Giusseppe Cimbali. Ambos coincidían, no obstante, en la solución pacífica de los conflictos sociales, moviéndose dentro del "racionalismo armónico".

${ }^{49}$ Nuevamente es interesante el paralelismo con el personamiento organicista de Gierke, para el cual el Estado es una asociación más en el mundo de las formas supraindividuales en que se expresa la vida humana en común.
} 
sindicatos- permitían enlazar orgánicamente a la clase obrera con la totalidad del cuerpo social y en particular con el Estado ${ }^{50}$. El organicismo espiritualista de Posada no le hizo ignorar los problemas del poder y de la lucha por el Derecho, aunque siempre defendiera que el Estado democrático debería ser un Estado garantista y de tutela de los valores fundamentales del sistema democrático ${ }^{51}$. Su planteamiento utópico se concreta en la propuesta de una "democracia orgánica", camino intermedio ${ }^{52}$ superador de los dos polos antagonistas representados por el liberalismo individualista y mecánico y el socialismo, pero con el mantenimiento de la democracia parlamentaria y, en general, de sus instituciones básicas ${ }^{53}$. Dato a destacar es su compromiso con los pilares fundamentales de la democracia liberal: La democracia no puede estimarse como una rectificación del liberalismo, sino como un desarrollo expansivo e intenso del liberalismo, y enderezado a hacer práctica y fecunda la conjunción de la libertad y de la igualdad: una libertad con contenido ético y económico

Esa concepción va abrir el camino a la gran corriente del pluralismo político y jurídico, encontrándose aquí el germen de su crítica a la concepción a la concepción estatalista del Derecho y a la idea de soberanía unilateralmente ejercida y personificada en el Estado. Véase, al respecto, GONZÁLEZ VICEN,F.: "La teoría del Derecho y el problema del método jurídico en Otto von Gierke", en Estudios de Filosofía del Derecho, Santa Cruz de Tenerife, Facultad de Derecho-Universidad de la Laguna, 1979, págs.273 y sigs. Quizá no es inoportuno llamar la atención sobre el filón común del organicismo de Gierke y Krause, a saber: el pensamiento de Fichte. Ese filón del pluralismo jurídico y político puede verificarse en el ensayo de GURVITCH,G.: "Otto von Gierke als Rechtsphilosophon", en Logos, Bd.XI (1922-1923).

${ }^{50}$ El planteamiento se oponía al sindicalismo de clase y de tipo revolucionario. Puede consultarse la posición de Georges Sorel, en SOREL, G.: Reflexiones sobre la violencia, edición y estudio preliminar, "Teoría e ideología del sindicalismo en Georges Sorel" (pp. XI-LXIV), por J.L. Monereo Pérez, Granada, Ed. Comares (Col. Crítica del Derecho), 2011.

${ }^{51}$ No en vano había traducido en su juventud la conocida obra de IHERING,R.V.: La lucha por el Derecho, trad.Adolfo Posada, y Prólogo de Leopoldo Alas (Clarín), Madrid, Lib.Gral de Victoriano Suárez, 1921 (Reeditada, con estudio preliminar a cargo de J.L. Monereo Pérez, Ed. Comares (Col. Crítica del Derecho), 2008). Esa traducción y su oportunidad es evocada en POSADA,A.: Fragmentos de mis Memorias, Oviedo, Universidad de Oviedo, Cátedra Aledo, 1983, págs.116-117: "tradúzcalo usted: es oportunísimo", le espetó Alas (Ibid.,pág.117). No obstante criticó la concepción de Ihering en lo que se refiere a la primacía del interés, porque a su entender el Derecho se acaba confundiendo con el egoísmo de los que tienen intereses protegidos. Cfr. POSADA,A.: "Sobre el aspecto jurídico del problema social", en Revista General de Legislación y Jurisprudencia, núm.92 (1898), págs.73-74. Pero esto dicho precisa su posición al respecto: "El pobre, como no representa un interés poderoso, una potencia viva tradicional, se hallará siempre, en la lucha por el derecho, en condiciones desfavorables, porque le falta el poder que el interés jurídicamente protegido supone" (Ibid.,págs.74-75).

${ }^{52} \mathrm{Ni}$ la solución dictatorial de Rusia, ni la solución autoritaria de la burguesía. En esto último, hacía notar que "la burguesía, que cediera y prometiera tanto para que el proletariado no discrepara ante la guerra, y que al llegar la paz aceptara la Parte XIII del Tratado de Versalles, relativa a los derechos del trabajo, se arrepintiese ahora y organiza ofensivas para destruir su propia obra social y querría restaurar íntegramente el régimen del capitalismo anterior. Y la "reacción" se acentúa, y la democracia se detiene". Cfr. POSADA,A.: "Reflexiones sobre la crisis del liberalismo", en POSADA,A.: Actitud ética ante la guerra y la paz, Madrid, Caro Raggio Editor, 1923, pág.206. Su propuesta de "democracia orgánica" es distinta a la que realizara Ramiro de Maeztu, en su obra La crisis del humanismo, edición de María de Maeztu, Buenos Aires, Sudamericana, 1948, págs.143 y sigs., donde el hombre no es el centro del sistema sino el instrumento, en cuanto simple portador de sentido objetivo (Ibid.,pág.315). Sobre el pensamiento de Maeztu, en general, véase VILLACAÑAS,J.L.: Ramiro de Maeztu y el Ideal de la Burguesía en España, Madrid, Espasa Calpe, 2000.

${ }^{53}$ Véase POSADA,A.: Teoría social y jurídica del Estado. El Sindicalismo, Buenos Aires, Librería J.Menéndez, 1922, págs.45 a 48. Reeditada, POSADA,A.: Teoría social y jurídica del Estado. El Sindicalismo, edición y estudio preliminar, "Sindicalismo reformista integrado y Estado democrático en el republicanismo social de Adolfo Posada" (pp. IX-LXIV), a cargo de J.L. Monereo Pérez, Granada, Ed. Comares (Col. Crítica del Derecho), 2018. 
y una igualdad inicial jurídica, no arbitraria ni demoledora ${ }^{54}$. Su apuesta era una sincera defensa del orden democrático en crisis por la "causa social" (problema social) y por las dificultades para garantizar la paz (imperialismo) en el campo de las relaciones internacionales ${ }^{55}$.

En todo esto había una esencial coincidencia con su maestro Azcárate ${ }^{56}$, cuyo ideario político presuponía la libertad en la igualdad y el régimen democrático basado en el sufragio universal y la autenticidad de la representación política ${ }^{57}$, y un sistema pluralista de partidos que expresen la variedad infinita de sentidos y modos de ver que respecto del Derecho y de la justicia se dan en el seno de la sociedad. Aparte de la defensa de una forma de Estado democrático intervencionista fuertemente comprometido con la realización de la justicia social. Su compromiso con la democracia se reflejó en pensamiento y acción política: siempre puso como única base admisible para la organización de todos los poderes del Estado el principio de la soberanía nacional o del self-government, según la expresión inglesa que él incorporó a la terminología política española. La soberanía nacional era la única fuente de poder, a juicio de Azcárate, en todo Estado normalmente organizado ${ }^{58}$, pues, como dijera Hauriou, la soberanía nacional significa que la nación llega a ser propietaria de su gobierno: la soberanía es la propiedad del poder y el problema que plantea consiste en averiguar en nombre de quién se gobierna; se gobernó primeramente en nombre del rey, y era el rey quien tenía la propiedad del poder de gobierno; en adelante, con la democracia, se gobernará en nombre de la nación, y esto significa que la nación adquiere la propiedad del poder de gobierno ${ }^{59}$. Por ello Posada denunció los vicios y corruptelas que pervierten al régimen parlamentario, especialmente combativo se mostró respecto a toda clase de desvirtuación del sistema electoral ${ }^{60}$.

\footnotetext{
${ }^{54}$ POSADA,A.: "Reflexiones sobre la crisis del liberalismo", en POSADA,A.: Actitud ética ante la guerra y la paz, Madrid, Caro Raggio Editor, 1923, pág.202.

${ }^{55}$ In fine, POSADA,A.: "Reflexiones sobre la crisis del liberalismo", en POSADA,A.: Actitud ética ante la guerra y la paz, Madrid, Caro Raggio Editor, 1923, págs.200 a 207.

${ }^{56}$ Es reconocimiento se refleja en el artículo de Adolfo Posada en el semanario España, a propósito de la jubilación de Azcárate como catedrático de Universidad. El texto muy emotivo se recogo íntegramente en AZCÁRATE,G.: Gumersindo de Azcárate. Estudio biográfico documental, Madrid, Tecnos, 1969, págs.530 a 531. En fecha más reciente, TUR FERRER,A.: El pensamiento social de Gumersindo de Azcárate, Madrid, 1995; VATTIER FUENZALIDA,C.: Gumersindo de Azcárate y la renovación de la ciencia del Derecho en el siglo XIX, Madrid, Colegio de Registradores de la Propiedad y Mercantiles de España, 1998.

${ }^{57}$ Véase AZCÁRATE,G.: Gumersindo de Azcárate. Estudio biográfico documental, Madrid, Tecnos, 1969, págs.66 y sigs., passim. Esta obra contiene una selección de escritos de Azcárate de extraordinaria utilidad para conocer su pensamiento y en general del krausismo liberal progresista.

${ }^{58}$ AZCÁRATE,G.: Gumersindo de Azcárate. Estudio biográfico documental, Madrid, Tecnos, 1969, pág.67. Véase la edición AZCÁRATE, G.DE.: El self-government y la Monarquía doctrinaria, edición, estudio preliminar (pp. XI-LXXX) y notas, a cargo de Gonzalo Capellán de Miguel, Madrid, Centro de Estudios Políticos y Constitucionales, 2009.

${ }^{59}$ HAURIOU,M.: Derecho público y constitucional, trad.C.Ruíz del Castillo, Madrid, Ed.Reus, 1927, pág.245 (HAURIOU, M.: Principios de Derecho Público y Constitucional, traducción, estudio preliminar, notas y adiciones por Carlos Ruiz del Castillo, edición al cuidado de J.L. Monereo Pérez, Granada, Comares (Col. Crítica del Derecho), 2003).

${ }^{60}$ AZCÁRATE,G.DE.: El régimen parlamentario en la práctica (1885), Prólogos de Adolfo Posada y E.Tierno Galván, Madrid, Tecnos, 1978.
} 
Un dato a destacar es el creciente valor político de las formaciones sociales que los integran. Existe en el Estado contemporáneo un doble movimiento: por una parte, el Estado propende a unificar, ordenar e intensificar su acción, interviniendo en sus funciones directivas en todos los intereses humanos; por otra, la sociedad reclama cada día más autonomía y más eficacia para las formaciones sociales -Sociedades, Asociaciones, Sindicatos, Comunidades, Corporaciones- que viven en el Estado. Reflejo de este fenómeno es el movimiento general de reivindicaciones que supone el sindicalismo, especialmente en las luchas económicas (el "hecho sindical", es el más intensamente representativo de la vida colectiva contemporánea, sobre todo en cuanto el sindicalismo significa una forma y un método generales de organización de los elementos y fuerzas sociales, y constituye una expresión de la división del trabajo social de los que hablan Durkheim y Duguit) ${ }^{61}$. Se trata de garantizar un equilibrio entre autonomía individual y colectiva y heteronomía pública como elemento imprescindible de la organización de la sociedad. Sin la dimensión colectiva la imagen en la sociedad del individuo y del ciudadano queda incompleta. Sin embargo, paradójicamente, piensa que la resultante de todos estos movimientos parece ser una mayor unidad política en el Estado constituido sobre la base del concurso de todas las fuerzas sociales organizadas ${ }^{62}$. Como puede comprobarse Posada era optimista respecto de la posibilidad de reconducir hacia el Estado político el pluralismo de las fuerzas sociales organizadas, lo cual tendría la vertiente positiva de integrar y armonizar la divergencia de intereses en el interés general identificado en cada momento histórico. Puede hablarse respecto de Posada -que asume las ideas de Giner- de una concepción pluralista de base organicista social, que ve en el "Estado político" un instrumento para elevar el tipo de vida individual y de las colectividades inferiores -municipios, regiones, sociedades especiales-, conservando estas múltiples "formaciones sociales" (nacidas como reflejo del proceso de diferenciación social) su propia identidad y personalidad generado de Derecho.

\section{Reforma de la "Constitución política" en el sentido de la implantación de un sistema democrático ante la crisis del sistema liberal: La "democracia orgánica" del republicanismo social krausista}

"La nueva imagen del hombre es en comparación con el esquema abstracto de la libertad, el interés propio y racional de la época liberal, un tipo mucho más próximo a la vida en el cual es incluida también la relación de poder intelectual,

\footnotetext{
61 POSADA, A.: Teoría social y jurídica del Estado. El sindicalismo, edición y estudio preliminar, "Sindicalismo reformista integrado y Estado democrático en el republicanismo social de Adolfo Posada" (pp. IX-LXIV.), al cuidado de J.L. Monereo Pérez, Granada, Comares (Col. Crítica del Derecho), 2018, pág. 68. Observa que, por otra parte, "el sindicalismo ha contribuido, con su influjo excepcionalmente decisivo, a provocar, educar y definir el sentido de la cooperación solidaria, y a despertar la conciencia del deber social gracias a la estrecha relación que el sindicato (la asociación a la defensiva y a la ofensiva) establece entre el sindicato y la función que el sindicato constituido ha de desempeñar con vistas al interés común, o sea realizando la finalidad que sirve de razón al grupo o formación sindical y que ha determinado su constitución" (Ibid., pág. 6).

${ }^{62}$ POSADA,A.: "Derecho político y administrativo", en POSADA,A.y otros.: Derecho usual, Madrid, Ediciones de la Lectura, s/f, pág.49.
} 
económico y social del sujeto jurídico [...]. El hombre en el derecho [...] no es ya el individuo aislado, sino el hombre en sociedad, el hombre colectivo. Nos hallamos frente a una transformación de nuestro concepto de democracia: el pensamiento democrático proyectado sobre el individuo aislado es repensado desde la perspectiva del hombre colectivo"

GUSTAV RADBRUCH ${ }^{63}$

Adolfo Posada se inscribe en la corriente liberal del krausismo español, y en coherencia con ello, suscribe una concepción humanista del liberalismo marcando nítidas diferencias con el liberalismo doctrinario ${ }^{64}$. La comprensión de su pensamiento no puede efectuarse sin atender a la particular forma de cristalización liberal democrática que se implantó en nuestro país en el período comprendido entre 1890 a 1923. Es una etapa que puede ser caracterizada, sin excesos, como etapa del parlamentarismo oligárquico y del caciquismo rural, en un contexto marcado por la crisis colonial (1890-1898) y, por la en parte paralela, y agudizada posteriormente, crisis social y político-institucional del año $1917^{65}$. El sufragio universal estaba desnaturalizado, debido a que el sistema "oligárquico y caciquil" y la corrupción se consagraron en la Restauración como práctica institucional "consentida" y asumir una verdadera voluntad regeneradora. Este sistema, a pesar de los intentos de revisión "desde dentro", mostraba los límites reales para una evolución democratizadora.

El sufragio, pese a algunos progresos, estaba viciado por el régimen electoral y de partidos imperante en la Restauración. Punto que quedó especialmente destacado con la crisis de 1909 ("Semana Trágica" de Barcelona), e inercia de los partidos tradicionales para afrontarla. En realidad, en la dialéctica de los partidos turnantes, acabó prevaleciendo los grandes intereses conservadores profundamente reaccionarios, intolerantes y antimodernizadores, lo que se reflejaría más nítidamente en el período crítico de 1917 en adelante, con el debilitamiento del régimen político, y el advenimiento de la Dictadura de Primo de Rivera en 1923 (con la suspensión de la Constitución y de las libertades fundamentales), y después, en la reacción conservadora ante la segunda República en 1936. En este ciclo largo de la vida política de nuestra país, toda progreso en la democratización política y social encontró sus "frenos", sus resistencias conservadora, con la dialéctica reforma-retroceso institucional, cuando simple "involución" en el ya precario sistema democrático. De manera que se hizo realmente imposible llevar a cabo la solución reformista-evolucionista dentro de la legalidad constitucional vigente. Con la instauración del régimen de excepción (Dictadura del período de 1923 a 1930), se abolió el régimen de

63 RADBRUCH, G.: El hombre en el Derecho. Conferencias y artículos seleccionados sobre cuestiones fundamentales del Derecho, trad. Aníbal del Campo, revisión, edición y estudio preliminar, "Gustav Radbruch: un modelo de jurista crítico en el constitucionalismo democrático social" (pp. IX-LXIII), a cargo de J.L. Monereo Pérez, Granada, Comares (Col. Crítica del Derecho), 2020, pág. 7.

${ }^{64}$ Para esa cosmovisión general del krausismo español, véase DÍAZ,E.: La filosofía social del krausismo español, Madrid, Debate, 1989, passim. Para el liberalismo doctrinario, véase la obra clásica de DÍAZ DEL CORRAL, El liberalismo doctrinario, Madrid, CEC,1983.

${ }^{65}$ En este sentido, MARTÍNEZ CUADRADO,M.: La burguesía conservadora (1874-1931), Madrid, Alianza, 1973, págs.369 y sigs. 
garantías constitucionales y se trató de implantar un sistema político corporativista, autoritario y decisionista, inspirado por el sistema totalitario que se percibía en países como Italia, y como emergente en otros países europeos, y bajo la influencia -interpretada en clave corporativo autoritaria- del pensamiento social de la Iglesia. Lo que en el marco de la legislación tuvo su expresión cualificada en la carta corporativa del trabajo a través del Decreto-Ley de 26 de noviembre de 1926, sobre Organización corporativa nacional, a instancia de Eduardo Aunós. Se dictaría el llamado "Código del Trabajo" de 1926, y la normativa relativa a los "comités paritarios" -en clave también corporativa y sustitutiva del sindicalismo libre-; y se suprimió en 1924 el Instituto de Reformas Sociales. Con el mantenimiento en todo momento del régimen de excepción se llega al agotamiento institucional del modelo autoritario, lo que se expresa en el Pacto de San Sebastián de 17 de agosto de 1930, y la ulterior formación del Gobierno provisional del 14 de abril, que proclamaría la Segunda República. Este proceso marcaría no sólo la transición de la Dictadura a la Democracia, sino más ampliamente el largo y tortuoso tránsito del precario Estado liberal burgués hacia la forma del Estado social de Derecho, con la consiguiente reforma de la constitución política y de la constitución socio-económica. Proceso de cambio -ciertamente complejo y contradictorio- que se emprende resueltamente en el período contradictorio de la Segunda República ${ }^{66}$.

El suyo era un humanismo idealista propio de los "democráticas de cátedra" del krausismo. Ese entendimiento del liberalismo desemboca en el reformismo social a cargo del Estado, reconociendo la necesidad "de una acción social en forma de tutela protectora". Hasta aproximarse fuertemente a las posiciones del "socialismo de Estado"67: apreciándose un

\footnotetext{
${ }^{66}$ Véase, en general, GONZÁLEZ CALBET,M.T.: La Dictadura de Primo de Rivera. El Directorio Militar, Madrid, Eds. El Arquero, 1987.

${ }^{67} \mathrm{El}$ "socialismo de Estado" era defendido por por los socialistas de cátedra (Wagner, Schmoller, Brentano, y en gran medida Schäffle, Sombart, Herkner, etc.) los cuales defendían la intervención del Estado en la economía capitalista asumiendo nuevas funciones de ordenación, pero sin alterar completamente sus fundamentos, como medida de estabilidad económica y justicia social, pero también como elemento estratégico para la integración de los conflictos sociales emergentes motivados por la contraposición entre el capital y trabajo como fuerzas productiva. La inteligente estrategia de Bismarck fue asumir buena parte del programa de los reformistas de cátedra realizando un programa mínimo de intervenciones sociales y laborales (los seguros sociales y las normas reguladoras del trabajo asalariado) con expresa finalidad de contrarrestar las propuestas del movimiento sindical y del socialismo políticamente organizado (aunque desde el partido socialista alemán existían posiciones próximas desde Lassalle y especialmente con el "revisionismo" de Berstein). Se trataba de "quitarle las hierba de los pies". Fue una astucia de la razón hegeliana que siguieron poco a poco otras naciones. Véase HEYDE,L.: Compendio de Política social, trad. de R.Luengo Tapia y M.Sánchez Sarto, Barcelona-Buenos Aires, Labor, 1931; LAIDLER,H.: Historia del socialismo, Madrid, Espasa-Calpe, 1933, págs.409 a 413; GUSTAFSSON,B.: Marxismo y revisionismo, trad. de J.Muñoz, Barcelona, Grijalbo, 1975. En sus implicaciones para la reforma jurídico-social. Me he ocupado ampliamente de esta problemática en MONEREO PÉREZ,J.L.: Fundamentos doctrinales del Derecho social en España, Madrid, Trotta, 1999; MONEREO PÉREZ,J.L.: "Ludwig Heyde: La Seguridad Social en el marco de la Política y el Derecho Sociales", en Revista de Derecho de la Seguridad Social Laborum, n n 23, $2^{\circ}$ Trimestre 2020, págs. 357389. El socialismo de Estado, es llamado también (sobre todo por sus adversarios) el "socialismo de cátedra", por haberse desarrollado principalmente en las universidades alemanas, de donde se fue infiltrando en la legislación obrera de los Estados del centro de Europa, y en cualquier caso ejerciendo una fuerte influencia en todas las legislaciones europeas del período. Mantiene un posición contraria a la doctrina liberal individualista, y afirman que sin la intervención del Estado, los egoísmos se entrechocan, y el fuerte aplasta al débil. Es al Estado, representando intereses generales, al que pertenece la intervención para reprimir la lucha de las
} 
movimiento de reforma político-social que mantiene el sentido reformista de una progresiva política social, o sea, de un socialismo sin la dogmática socialista y sin el sentido que supone la lucha de clases aplicada como método transformador o revolucionario: un nuevo liberalismo $^{68}$. Su propuesta reside en la creación de un "Estado tutelar" neutral respecto a las clases sociales pero fuertemente comprometido en la garantía de la libertad y de la justicia social. Por ello ha de ser un Estado intervencionista, un Estado social. Para Posada, la el intervencionismo público en la vida social y económica a través de la legislación social no supone en sí un cambio de modelo de sociedad, ni un camino hacia la socialización en un sentido socialista, sino una revisión de los esquemas liberales de organización del capitalismo por un tipo de capitalismo organizado o intervenido ${ }^{69}$. Se puede decir que el intervencionismo se muestra como una solución transaccional entre las utopías socialistas y el optimismo individualista, igualmente peligroso, a nuestro parecer, para el orden social ${ }^{70}$.

Es, en términos de Posada, "un liberalismo rehecho vivificado por la sustancia socialista"71. Con ese republicanismo o liberalismo socializado postula la intervención pública en la ordenación de la economía y de las relaciones sociales (en el sentido de integración de las clases trabajadoras en la dinámica político-institucional del sistema político liberal) y asimismo el reconocimiento de los derechos económicos, sociales y culturales que complementan las libertades formales. Posada había comprendido la importancia política del sindicalismo, el cual debería de ser integrado en el marco de una estrategia de estabilización político democrática. Constataba la tendencia general existente en los Estados

individualidades opresivas y mantener el equilibrio entre los diferentes factores de la producción. Véase PIC,P.: Tratado elemental de legislación industrial, t.I., trad. Justo José de Urquiza, Madrid, Instituto Editorial Reus, 1942, págs.38 a 41. La terminología utilizada es reflejo de un fenómeno de "atracción" de las ideas socialistas al servicio diversos fines a los propios de esta corriente plural del pensamiento crítico. Decía significativamente Menger que "En estos diez último años, los principios socialistas han llegado á ser un elemento de la política general, y, por consiguiente, el juguete de los partidos políticos y religiosos". Cfr. MENGER,A.: El Derecho al producto íntegro del trabajo, versión castellana de Adolfo Posada, Madrid, B.Rodríguez Serra-Biblioteca de Filosofía y Sociología, Editor,1886, cap.XI, págs.175 y sigs. ("El socialismo conservador en Alemania"); redición: MENGER, A.: El Derecho al producto íntegro del trabajo. El Estado democrático del trabajo (El Estado Socialista), edición y estudio preliminar, "Derechos sociales y Estado democrático social en Antón Menger” (pp. XI-LXXVIII), Granada, Comares (Col. Crítica del Derecho), 2004. Véase, SCHMOLLER, G.: Política social y economía política, trad. Lorenzo Benito, revisión, edición y estudio preliminar, "La Escuela Histórica Nueva en economía y la política de reforma social” (pp. V-XXXVI), a cargo de J.L. Monereo Pérez, Granada, Comares (Col. Crítica del Derecho), 2007; MONEREO PÉREZ, J.: El 'Socialismo de cátedra' de Gustav Schmoller en la construcción de la Política social moderna, en Revista Europea de Historia de las Ideas Políticas y de las Instituciones Públicas, 2017, issue 11. https://econpapers.repec.org/article/ervrehipi/y 3a2017 3ai 3a11 3a03.htm

${ }^{68}$ POSADA,A.: Teoría social y jurídica del Estado, cit.,pág.58.

${ }^{69}$ Véase HILFERDING,R.: El capital financiero (1909), trad. V.Romano García, Madrid, Tecnos, 1973, reimpresión de la 2a ed., de 1963; y MONEREO PÉREZ,J.L.: Estado y democracia en Otto Kirchheimer, Estudio preliminar a KIRCHHEIMER,O.: Justicia política. Empleo del procedimiento legal para fines políticos, Granada, Comares (Colección Crítica del Derecho), 2001, págs. XVII- CLXXXV, sobre el origen de estas propuestas y su compatibilidad con una revolución pacífica, propiamente jurídica del capitalismo en el primer tercio del siglo veinte.

${ }^{70}$ PIC,P.: Tratado elemental de legislación industrial, t.I., trad.Justo José de Urquiza, Madrid, Instituto Editorial Reus, 1942, pág.13.

${ }^{71}$ Evolución legislativa del régimen local en España, cit., pág.VIII. 
contemporáneos a la transformación de su estructura política a consecuencia de la intensificación del espíritu o sentido social " sindicalista aunque también "localista", generador de las más ricas y variadas formas de asociación o condensación de fuerzas, que pugnan por afirmarse y manifestarse, de modo expreso en la vida constitucional, como factores de valor y eficacia políticos, y suscitador el ser el fundamento de tendencias descentralizadoras o hacia la autonomía en los centros de vida local, especialmente a veces la "regional"72. De este modo para Posada la reforma social debería ir ligada inseparablemente a la reforma política, esto es, a la democratización del sistema. No se podía avanzar en el campo de la reforma social (con una expansión de los derechos de ciudadanía) sin proceder a una transformación constitucional del régimen político. Esta sincronización del proceso de reforma no se produciría en nuestro país hasta la proclamación y advenimiento de la II ${ }^{\mathrm{a}}$ República. Durante su vigencia se intentó establecer un estatuto jurídico (constitucional y legal) de la clase trabajadora, aunque su aplicación encontró obstáculos en la clase empresarial y, en cualquier caso, no pudo realizarse plenamente. El programa social de la II $\square$ República se apartaría de la orientación corporativa, tanto en la organización del sistema de relaciones laborales como respecto a la articulación del sistema de representación (se rechazaron todas las propuestas dirigidas a establecer en el Estado una representación corporativa de los intereses). La ilusión krausista de un orden político y social orgánico y armónico ("racionalismo armónico") como alternativa la crisis del sistema liberal individualista y autoritario se había desvanecido para siempre.

Para Posada el republicanismo social se basa, pues, en la intervención social dirigida a otorgar un contenido social a la acción del Estado mediante la incorporación de un contenido económico y cultural a las libertades y derechos constitucionales, es decir, la transformación del sistema de derechos del hombre y del ciudadano ${ }^{73}$. Su apuesta estriba en un proceso reformista evolutivo de cambio cualitativo del régimen liberal individualista: una transformación pacífica de carácter social y jurídico del Estado ${ }^{74}$. En realidad, era una convicción común el que la legislación social y laboral era "un medio de evitar luchas violentas y de ir preparando un estado de paz para el futuro"75. Es una línea la que se establece aquí con su afirmación de un "organicismo psicologista" que en gran medida había recibido de Alberto Schäeffle ${ }^{76}$ apartándose del organicismo biologista de Herbert

\footnotetext{
72 POSADA,A.: Tratado de Derecho político, t.II, Madrid, Librería General de Victoriano Suárez, 1935, pág.t555.

${ }^{73}$ En este sentido POSADA,A.: La crisis del Estado y el Derecho político, cit., pág.7.

${ }^{74}$ Explícitamente, POSADA,A.: La reforma constitucional, cit., pág.14, y Teoría social y jurídica del Estado, cit.,pág.25. El evolucionismo pacífico es una idea que, pese a las distancias de concepciones, está influenciada por el pensamiento del SPENCER: Principios de sociología,. cit., a él dedica particular atención en su obra POSADA,A.: Principios de Derecho político.,cit., págs.292 y sigs. Spencer ejerció una gran influencia en el pensamiento krausista., aunque progresivamente se aparte de él, especialmente respecto a su organicismo biológico.

${ }^{75}$ DORADO MONTERO,P.: Del problema obrero, Salamanca, 1902, pág.39.

${ }^{76}$ Ya apreciado por el referente ético del krausismo español, GINER,F.: "El socialismo de Schaeffle", en BILE, núm.19 (1895), págs.207 a 213. Posada había traducido junto con Buylla, su obra La quintaesencia del socialismo, Madrid, 1885. Sobre la recepción de su pensamiento en Posada, véase POSADA,A.: Sociología contemporánea, cit., págs. 161 y sigs.
} 
Spencer ${ }^{77}$, y del riesgo de sus posibles derivaciones del "spencerismo social" hacia el darwinismo social ${ }^{78}$. Posada se encontraba especialmente próximo a la sociología psicológica, la cual (como había señalado L.F.Ward, con el que mantiene una especial afinidad de puntos de vista), Wundt ${ }^{79}$, Sigwart, y el segundo Fouillée ${ }^{80}$ - se postulaba como el fundamento de las teoréticas disciplinas que son las ciencias del espíritu ${ }^{81}$. Ello obedecía a una elección ideológica coherente con el ideario cultural del organicismo ético krausista y con la necesidad de dar respuesta a la emergencia del nuevo contexto político y social en los esquemas conceptuales liberal krausistas ${ }^{82}$. Ya en su Breve historia del krausismo español, había apreciador el sentido esencialmente orgánico del Derecho político en Giner, "pero de una profunda originalidad frente a las tendencias entonces invasoras del organicismo

\footnotetext{
${ }^{77}$ Una primera aproximación de Posada al pensamiento de Spencer, que en una fase posterior criticaría más severamente en el aspecto del organicismo biologísta, en POSADA,A.: "Descripción del hombre primitivo según Spencer", en BILE 16 (1892), págs.231 a 233.

${ }^{78}$ Véase GONZÁLEZ VICÉN,F.: "El darwinismo socal: Espectro de una ideología", en Anuario de Filosofía del Derecho, T.I (nueva época), Madrid, 1984, págs.163 a 176; y la "revisión" matizada de esta aproximación hecho por BETANCOR CURBELO,D.: "F.González Vicén y el darwinismo social", Problemática actual de la historia de la filosofía del Derecho Española, ed. a cargo de F.Puy M.C.Rovira y M.Otero, Santiago de Compostela (Universidad), 1994, pás.101 y sigs.

${ }^{79}$ Sobre el pensamiento de Wundt se había ocupado antes Giner, en GINER DE LOS RÍOS,F.: Persona social. Estudios y fragmentos, Madrid, Librería General de Victoriano Suárez, 1899 (reeditada en Comares, con estudio prelimar a cargo de J.L. Monereo Pérez, 2008), págs.135 y sigs., y 163 y sigs., del cual le interesa su concepción del organismo social y de persona social.

${ }^{80}$ Para el primer Fouillée, con el que mantuvo una inicial aproximación a través de la importante traducción de su obra, La ciencia social contemporánea, trad., Prólogo y notas de Adolfo Posada, Madrid, La España Moderna, 1894; y el ensayo POSADA,A.: "La filosofía y la pedagogía de Alfredo Fouillée", en BILE, núm.15 (1891), págs.289 a 300 y 305 a 314. De cualquier modo, en Posada ejerció un fuerte influjo la filosofía de Fouillée cada vez más marcadamente solidarista y su vertebración a través de la invención de la noción de "idea-fuerza" evolutiva. Fouillée ejerció una notable influencia en el propio pensamiento de Francisco Giner, como puede comprobarse la en la referencia constante a su obras (especialmente La ciencia social contemporánea que después tradujera Adolfo Posada) en GINER DE LOS RÍOS,F.: Persona social. Estudios y fragmentos, Madrid, Librería General de Victoriano Suárez, 1899, págs.8, 13, 14, 31, 75 a 85, y largo etcétera. En él subraya Giner su carácter esencialmente crítico y polémico y su tendencia a conciliar a amigos y adversarios del organismo social (Ibid.,pág.75). Nótese, por cierto, que Giner se hace eco ya de la traducción española realizada por Adolfo Posada, pág.75, nota 1; y la crítica a Fouillée por la reducción del organismo social a puro organismo biológico (la sociedad como "vasto organismo fisiológico") (Ibid.,págs.82-83).

${ }^{81}$ Véase SOMBART,W.: Noosociologia, Madrid, IEP, 1962, págs.155 y sigs.

${ }^{82}$ Según Posada la filosofía del Derecho de Giner se edifica y se sostiene siempre sobre su cimentación ética revistiendo en su total desarrollo un carácter netamente sociológico-orgánico. Es más: en cierto sentido podría afirmarse que la filosofía del Derecho del maestro se realiza como una sociología jurídica, de base ética en todo momento, de raíz metafísica y de contenido social interesante a la propia concepción iusfilosófica. Es así que razona Giner, tanto desde la filosofía del derecho como desde la sociología - al modo de Gierke (adviértase, nuevamente, la concomitación de pensamiento desde el organicismo historicista de Gierke- la realidad, no precisamente la realidad biológica del spencerismo, y menos la de Lilienfeld o Worms, sino la realidad orgánica de la persona social. El "Estado social" no sólo es, con Giner, un todo, una persona sino que por selo es también un organismo. Ello le permite conecta el pensamiento de Giner con el de Suárez: se podría establecer -afirmacierto enlace sociológico entre la filosofía de Giner y la posición doctrinal del más grande de Suárez. Yo he procurado establecer una relación de coincidencia esencial entre el organicismo social de Giner y el cuerpo místico del padre Suárez. La sociedad humana, en efecto, para éste no es un mero agregado de hombres, una pluralidad; es, en rigor, un ser, "cuerpo místico, comunidad substantiva". Cfr. POSADA,A.: Breve historia del krausismo español, Universidad de Oviedo. Servicio de Publicaciones, Oviedo, 1981, pág.107, con referencia a su ensayo "Cuerpo místico y organicismo social", Apéndice III de sus Principios de Sociología, vol.II, $2^{\mathrm{a}}$, ed., Madrid, Manuel Jorro, 1929.
} 
sociológico de Spencer, de Lilienfeld... y hasta de Alfredo Fouillée"83. Su organicismo ético se vincula con el organicismo historicista de Gierke ${ }^{84}$, quien para Posada es heredero cultural de Krause ${ }^{85}$, y su concepción del "racionalismo armónico"; éste es en el fondo un "místico racionalista" 86 , con muchas afinidades con Fichte ${ }^{87}$. Giner ya había afirmado la existencia de un principio de armonía, tanto dentro del orden particular del Derecho cuanto en el total de la vida, de manera que el Derecho para nada necesita ni supone lucha ni discordia como condición de su realización en la vida. Ello es así por la solidaridad de todos los seres jurídicos y de todas sus pretensiones legítimas se deriva inmediatamente del carácter orgánico de este principio, que excluye todo antagonismo y tiene por propia forma la paz; es decir, la actividad concertada de todas las fuerza vivas en mutua cooperación ${ }^{88}$. Su concepción liberal organicista de la sociedad como organismo social, no como un organismo entendido como unidad biológica, pero sí como un organismo de naturaleza social y de composición pluralista con base a la presencia de cuerpos intermedios entre el individuo y el Estado ${ }^{89}$. Según Posada, el movimiento sindicalista, aun reducido a su significación más

\footnotetext{
${ }^{83}$ POSADA,A.: Breve historia del krausismo español, cit.,págs.85-86. Ello no impidió que incluyo tradujera a algunos de estos autores, es el caso de Alfredo Fouillée (La ciencia social contemporánea, trad., Prólogo y Notas de Adolfo Posada, Madrid, La España Moderna, 1894). Fouillée fue uno de los creadores de la sociología psicologista y voluntarista, de ahí su recepción coherente desde el krausismo institucionista y su influjo sobre todo en el primer Posada.

${ }^{84}$ MONEREO PÉREZ, J.L.: La teoría jurídica y social de Otto von Gierke: Teoría del Derecho Social y de las personas colectivas, estudio preliminar a Gierke, O.von: La función social del Derecho privado y otros estudios, Trad. José M. Navarro de Palencia, revisión y edición a cargo de J.L. Monereo Pérez, Granada, Comares (Col. Crítica del Derecho), pp. IX-LXI, 2015.

${ }^{85}$ Véase esta explicación en el propio POSADA,A.: Breve historia del krausismo español, cit.,pág.44: "La sociedad, dice Gierke, 'no encuentra una expresión suficiente en el Estado, se manifiesta también en una gran variedad de órdenes diversos con estructras y fines específicos -la Familia, la Iglesia, el Municipio-'. Y podríamos ahora añadir los sindicatos o mejor los grupos. Gierke, para Gurvitch, es quien "ha transmitido directamente la preciosa herencia de la tradición de Fichte y de Krause a la Constitución de Weimar". Sobre el marco cultural de referencia del pensamiento de Krause, véase GURVITCH,G.: L'idée du droit social. Notion et système du droit social. Histoire doctrinale du XVII siècle jusqu'à la fin du XIXe siècle, París, Sirey,1932 (Edición, traducción y estudio preliminar de J.L. Monereo Pérez y A. Márquez Prieto, Granada, Comares (Col. Crítica del Derecho), 2005. Sobre el significado de Krause en el contexto de la filosofía del idealismo alemán y su incidencia en nuestro países, véase también el libro clásico de DÍAZ,E.: La filosofía social del krausismo español, Madrid, Debate, 1989, espec.,págs.38 y sigs.

${ }^{86}$ UREÑA,E.: Krause, educador de la Humanidad, Madrid, Publicaciones de la U.P. Comillas U.E., 1991.

${ }^{87}$ Subraya esta idea el propio Posada, con apoyo directo en GURVITCH, G.: L'idée du Droit Social. Notion et Système du Droit Social, París, 1932 (Edición, traducción y estudio preliminar de J.L. Monereo Pérez y A. Márquez Prieto, Granada, Comares (Col. Crítica del Derecho), 2005), con el cual por cierto mantiene grandes coincidencias de fondo. Sobre Gurvitch, véase MONEREO PÉREZ,J.L.: Pluralismo jurídico y Derecho social, en Est. prel., a la obra de GURVITCH,G.: Elementos de sociología jurídica, Granada, Comares (Colección Crítica del Derecho), 2001.

${ }^{88}$ Y añade que hay, cierto, una lucha en pro del Derecho y contra la injusticia. Pero la posibilidad de lucha reparadora supone la perpetración de un atentado, contra el cual se ejerce; y esta perpetración, lejos de ser ley necesaria de la vida, guarda con ella la misma relación que la enfermedad con la salud. Cfr. GINER DE LOS RÍOS,F.,y CALDERÓN,A.: Resumen de Filosofía del Derecho, t.I., Madrid, Espasa-Calpe, 1926, págs.240241. En el seno de la relaciones laborales Posada piensa que "El presidente Wilson señala el camino: todo está en crear el ambiente de atracción amistosa entre capitalistas o empresarios y obreros; es preciso asociar al obrero a la empresa; que ésta no se apara el trabajador negocio ajeno que lo toma a su servicio por un precio; al contrario, ha de procurarse que la empresa sea para el obrero, como lo es para el empresario: "su propio y personal negocio". Cfr. POSADA,A.: Actitud ética ante la guerra y la paz, Madrid, Caro Raggio Editor, 1923, pág. 134.
}

${ }^{89}$ GINER DE LOS RÍOS,F.: La persona social, Madrid, Librería General de Victoriano Suárez, 1899, 
estricta e histórica es una configuración demostrativa de la naturaleza orgánica y compleja de las sociedades humanas, que no son meros agregados de individuos, sino que entrañan una complejidad de actividades funcionales que sólo alcanzan fecunda realización mediante la diferenciación de aquellas actividades, y su desempeño por organismos adecuados: las asociaciones, los sindicatos, las corporaciones, las funciones ${ }^{90}$.

Importa retener que Posada realiza una interpretación o lectura del pensamiento de Krause con base a su conexión con Fichte otorgándose, así, una dimensión más socializante: "la filosofía de Krause -dice- es una filosofía política, dinámica, de enjundia ética y de valor social. Descansa en el reconocimiento de una vocación moral de la humanidad que, según Krause -como según Fichte-, consiste "en trabajar de una manera espontánea y autónoma en la transformación y en la perfección de la sociedad humana sobre la tierra", sociedad que Krause concibe y define como organismo: pero no organismo biológico, sin espiritual, organismo de la libertad (Organismus der Freiheit)". Y añade que esta "es la idea que recogerá Gierke y desarrollará, como nadie quizá, Giner. G.Gurvitch (nótese la aceptación de esta lectura formulada también por Gurvitch desde la lógica de fundamentación del "derecho social"91) escribe que "la noción central de la filosofía del derecho, que Fichte comparte con Krause, es la del organismo ético y espiritual que difiere y se opone absolutamente al organicismo biológico"92. En su lectura -filtrada a través de la mirada de

pág.195. (Reedición crítica con estudio preliminar a cargo de J.L. Monereo Pérez, Granada, Comares (Col. Crítica del Derecho), 2008).

${ }^{90}$ Cfr. POSADA, A.: "La nueva orientación del derecho político", Estudio anexo a DUGUIT,L.: La transformación del Estado, cit., págs.311 y sigs. POSADA, A.: "La nueva orientación del derecho político", Estudio preliminar a DUGUIT,L.: La transformación del Estado, Madrid, Librería de Fernando Fé , [1910?] (Libro recogido en DUGUIT, L.: Las transformaciones del Derecho público y privado, edición crítica de tres monografías de Leon Duguit vinculadas por la idea-fuerza de las transformaciones del Derecho Público y Privado y el por entonces emergente (en estado naciente) Derecho Social, con estudio preliminar, “'Objetivismo jurídico' y teoría de los “derechos” en León Duguit” (pp. XI-XXXIX), a cargo de J.L. Monereo Pérez y J. Calvo González, Granada, Comares (Col. Crítica del Derecho), 2007).

${ }^{91}$ Gurvitch es un pensador original, fuertemente influido por el pensamiento de Maurice Hauriou, pero con una lectura muy distinta a la que hiciera Georges Renard. La construcción técnico-jurídica y iusfilosófica contemporánea del Derecho social se debe en gran medida a Gurvitch. Véase GURVITCH,G.: L'idée du Droit Sociale, París, Sirey, 1932 (traducción, edición y estudio preliminar a cargo de J.L. Monereo Pérez y A. Márquez Prieto, Granada, Comares (Col. Crítica del Derecho), 2005). Véase MONEREO PÉREZ,J.L.: Pluralismo jurídico y Derecho social: la sociología del Derecho de Gurvitch, Est.prel., a la obra de GURVITCH,G.: Elementos de sociología jurídica, Granada, Comares (Colección Crítica del Derecho), 2001. La concepción de Georges Renard, en RENARD, G.: Sindicatos, trade-unions y corporaciones, traducción aumentada con un Prólogo, un Apéndice y un índice bibliográfico sobre "El movimiento obrero español" por Manuel Nuñez de Arenas, revisión, edición y estudio preliminar, "El sindicalismo y el orden democrático" (pp. VII-CVII), a cargo de J.L. Monereo Pérez, Granada, Ed. Comares, 2014. Ampliamente, MONEREO PÉREZ, J.L.: Democracia pluralista y Derecho Social. La teoría crítica de Georges Gurvitch, Barcelona, Ediciones de Intervención Cultural/El Viejo Topo, 2021. El pensamiento de Maurice Hauriou queda perfectamente en su obra más completa, HAURIOU, M.: Principios de Derecho Público y Constitucional, traducción, estudio preliminar, notas y adiciones por Carlos Ruiz del Castillo, edición al cuidado de J.L. Monereo Pérez, Granada, Comares (Col. Crítica del Derecho), 2003.

${ }^{92}$ POSADA,A.: Breve historia del krausismo español, cit.,pág.43. La cita de Gurvitch, en GURVITCH,G.: L'idée du Droit Social. Notion et Système du Droit Social, París, 1932, el específico dedica a Krause, Parte IV, cap.II, y en particular págs.536, en relación con la reflexión anterior de la pág.447. (Existe traducción, edición y estudio preliminar a cargo de J.L. Monereo Pérez y A. Márquez Prieto, Granada, Comares (Col. Crítica del Derecho), 2005. 
Fichte y de Gurvitch- de Krause, Posada insiste en el pluralismo político-social subyacente a la filosofía de éste. Por ello señala que "la política que se inspira en la filosofía de Krause no es absorbente ni dominadora, como no lo es el Estado, su objeto, en la concepción krausista -ni en Krause, ni en Ahrens ${ }^{93}$, ni en Gierke, ni en Giner, ni en Azcárate. El Estado es una institución que no debe confundirse con la sociedad: institución legítima y esencial, pero en la medida en que se afirma como asociación particular entre las demás, integradas todas en una totalidad más amplia ${ }^{94}$. Su filosofía política no es totalitaria ni en el sentido más abiertamente abarcador de la absorción de todas las esferas de la sociedad, ni en el sentido autoritario de dominio absoluto y antidemocrático ${ }^{95}$ de la sociedad y de sus unidades sociales. Es preciso distinguir nítidamente la sociedad del Estado, o si se quiere decir expresivamente, la diferenciación entre sociedad civil y sociedad política (una distinción "tan fecunda y tan rectificada y negada hoy bajo el influjo de la idea y del hecho dictatorial del Estado totalitario- se determina claramente en Krause, cuya concepción del Derecho y del Estado -nociones inseparables- entraña la definición y sustantivación de la sociedad orden total- que comprende todas las formas de unión y de cooperación humana armonizadas en una Humanidad terrena organizada"96).

En efecto, considera que la filosofía política de Krause no conduce ciertamente a un Estado totalitario, sino a un Estado jurídico, construido sobre la idea de libertad, condición esencial para la realización del rico y complejo destino humano. Esto le conduce a afirmar, con Gierke, el pluralismo sociopolítico, de manera que la sociedad no puede encontrar una expresión suficiente en el Estado, ya que se manifiesta también en una gran variedad de órdenes diverso con estructuras y fines específicos -la Familia, la Iglesia, el Municipio, los sindicatos y los grupos en general. En esa línea de pensamiento hace propia la reflexión de Gurvitch en el sentido de que Gierke es quien ha transmitido directamente la preciosa herencia de la tradición de Fichte y de Krause a la Constitución de Weimar ${ }^{97}$. La proximidad con Gierke es manifiesta, como también con autores como León Duguit que había asimilado

\footnotetext{
${ }^{93}$ Cfr. AHRENS,H.: Curso de Derecho Natural ó Filosofía del Derecho, trad.Ruperto Navarro Zamorano, Madrid, 1841. Gil Gremades hace notar que el traductor estaba en la órbita del liberalismo radical. Véase GIL CREMADES,J.J.: "La dimensión política del krausismo en España", en Stvdia Ivridica (Boletim da Faculdade de Direito. Universidade de Coimbra), núm.45 (1999), pág.31; y el ensayo de TORRES MENA,J.: Biografía de D.Ruperto Navarro Zamorano, Madrid, Impr.Julián Peña, 1856, 29 páginas.

${ }^{94}$ POSADA,A.: Breve historia del krausismo español, Universidad de Oviedo. Servicio de Publicaciones, Oviedo, 1981, pág.43.

${ }^{95}$ Sobre la visión del totalitarismo y autoritarismo en el debate de finales del primer tercio del siglo veinte, véase MONEREO PÉREZ,J.L.: Est.prel., a SCHMITT,C.: El nomos de la tierra, Granada, Comares (Colección Crítica del Derecho), 2003, y la bibliografía allí citada. También del mismo autor, "Estado y democracia en Otto Kirchheimer", Est.prel., a la obra de KIRCHHEIMER,O.: Justicia política, Granada, Comares (Colección Crítica del Derecho), 2001.

${ }^{96}$ POSADA,A.: Breve historia del krausismo español, cit., pág.44.

${ }^{97}$ POSADA,A.: Breve historia del krausismo español, cit., págs.43-44. No puede olvidarse que Breve historia del krausismo español es una obra de madurez intelectual en la que estuvo trabajando hasta los primeros años de la década de treinta (véase para verificarlo la "Nota preliminar" a dicha obra, pág.9). Para un estudio contemporáneo sobre el significado fundacional del constitucionalismo democrático-social de la Constitución de Weimar (que se uniría a la Constitución Austriaca y a la Constitución de la II ${ }^{a}$ República Española), puede consultarse, VV.AA.: La Constitución de Weimar (Texto de la Constitución alemana de 11 de agosto de 1919), Madrid, Tecnos, 2019, con los estudios de Ottmar Bühler, Walter Jellinek y Costantino Mortati, y la presentación de edición de Juan Antonio García Amado.
} 
y desarrollado la concepción corporativa de Gierke y su defensa de los organismos grupales intermedios ${ }^{98}$. Posada enmarca esa concepción humanista dentro de una dimensión finalista e ideal: la Humanidad y el grupo humano total, constituido para realizar el total destino humano (el fin), pero a través de una multiplicidad de organizaciones sociales. Más precisamente, el Estado no es la sociedad; lo social que se produce en ella forma el contenido del Estado, y éste se define como la sociedad para el Derecho. El Estado es el organismo regulador de la sociedad entera, pero respetando sus sustantividad. El Estado es con Krause un organismo político para hacer efectivas las condiciones interiores y exteriores de nuestra humanización ${ }^{99}$. Es significativo hacer notar aquí que para G. Solari el Estado no es la sociedad, sino el medio del cual ésta se sirve para realizar sus fines, que no son tan sólo la protección de la individualidad, sino de conservación de defensa de la colectividad en sus fases distintas y progresivas de individualización ${ }^{100}$.

Sin embargo, el organicismo evolucionista chocaba con la realidad de una estructura política -la correspondiente a la "constitución oficial"- que no podía culminar una "revolución desde arriba" y estaba fuertemente comprometida con las fuerza dominantes -las que conformaban la "constitución real"-.

Es de significar que esta revisión del liberalismo exige una reforma propiamente constitucional: una reforma de la constitución jurídica de la sociedad y del Estado, lo que presupone un reclamo de la fuerza conformadora del texto constitucional. Se trata de conjugar la racionalidad formal y la racionalidad material en el interior de la propia Constitución. Por ello entiende, en primer lugar, que ha de instaurarse un verdadero Estado de Derecho; esto es, debe dotarse al Estado de un verdadero Estatuto jurídico, con régimen de garantías de los derechos de la personalidad humana y de la ciudadanía, y respecto de la conducta jurídica de los gobernantes que ejercen poderes o desempeñan funciones en el Estado $^{101}$. Pero no es suficiente el sistema de garantías propio del Estado liberal de Derecho,

\footnotetext{
${ }^{98}$ Sobre el pluralismo y el problema de la representación de los intereses, véase DICKMAN,H.: Industrial Democracy in America. Ideological Origins of National Labor Relations Policy, Illinois, Open Court, La Salle, 1987.

${ }^{99}$ POSADA,A.: Breve historia del krausismo español, cit., pág.45. Por ello insiste (como ya lo había hecho en su curso La crisis del Estado y el Derecho político, Madrid, 1935) en negación de la toda concepción agresiva del Estado totalitario, la cual, frente al krausismo liberal democrático, viene a dejar sentado que todo está en el Estado y nada humano y espiritual existe, y a fortiori, nada tiene valor fuera del Estado, que es la verdadera realidad del individuo. Ni individuos ni grupos fuera del Estado. El Estado -se añade desde esa concepción totalitaria rechazable- es una fuerza espiritual que resume todas las formas de la vida moral e intelectual del hombre (Ibid., pág.45).

${ }^{100}$ SOLARI,G.: Filosofía del Derecho privado, vol. I. La idea individual (1939), y II. La idea social (1950), Buenos Aires, Editorial Depalma, 1946-1950.

${ }^{101}$ POSADA,A.: El régimen constitucional. Esencia y formas. Principios y técnica, cit., pág.133. En una perspectiva próxima, aunque desde una posición cercana al "socialismo jurídico-científico", Pedro Pérez Díaz había ya advertido que la solución de la cuestión social exige como "programa mínimo" un proceso de reformas jurídico-sociales. Pilar esencial de la misma es la creación por parte del Estado de un "estatuto del trabajador", que delimite los derechos fundamentales que, como tal, le corresponde y que en cada momento puedan ser amparados y garantizados por los poderes públicos. Ello se situaría en una secuencia histórica en el desarrollo de los derechos fundamentales, desde los derechos civiles y políticos clásicos hacia la extensión de la ciudadanía con el reconocimiento de los derechos sociales, económicos y culturales. Por ello, así como se llegó a la declaración de los derechos del hombre y del ciudadano, de los derechos fundamentales de la personalidad del
} 
por lo que considera que es preciso a la par construir un Estado social de Derecho que garantice efectivamente los derechos sociales de la ciudadanía o, mejor, de la persona humana y la autonomía colectiva de los grupos sociales que coexisten en una sociedad abierta y pluralista ${ }^{102}$. En esta coordenadas constitucionales afirma que los derechos de la persona no deben contemplar a esta meramente como hombre abstracto, sino también, y más

hombre como individuo, y como miembro de una sociedad, es necesario ahora llegar a la formación de un estatuto del trabajador, del hombre como trabajadores en el que se determine los derechos y deberes de éste frente al capital. Esa evolución es condición para que las relaciones entre los dos fundamentales elementos de la producción se "dulcifiquen", impidiendo la enorme pérdida de intereses que la lucha entre ellos cuesta a la sociedad. Desde una perspectiva distinta (sobre todo porque se parte de la idea de que el contrato de servicios del Derecho alemán tiene sus raíces en el derecho de personas) Gierke defendió que el compromiso de prestación de servicios contiene una reserva de libertad, de la cual se deduce que no puede exigirse un servicio incompatible con la libertad. Ello es tanto más importante, cuando se repara en el hecho de que el trabajo fluye inseparablemente de la personalidad. El contrato de servicios recibe así la función jurídico-social de ser un pilar del orden social y continuó siendo, en la medida en que introduce al individuo en una asociación más amplia, un instrumento idóneo para buscar el complemento y la corrección del derecho individual vigente, regulándolo bajo una bóveda de normas del Derecho público y privado de las comunidades. Cfr. GIERKE,G.: Las raíces del contrato de servicios, trad., y Comentario crítico de G.Barreiro González, Madrid, Civitas, 1982; GIERKE,G.: La función social del Derecho Privado y otros estudios, edición y estudio preliminar, "La teoría jurídica y social de Otto von Gierke: teoría del Derecho Social y de las personas jurídicas" (pp. IX-LXI), a cargo de J.L. Monereo Pérez, Granada, Comares, 2015. La defensa de los derechos de la personalidad del trabajador se hizo desde el socialismo jurídico por MENGER,A.: El derecho civil y los pobres, trad.A.Posada, y Est.prel., de J.L.Monereo Pérez, Granada, Comares (Colección Crítica del Derecho), 1998.

Ese "estatuto" de ciudadanía social debe comprender, según Pérez Díaz, los derechos y deberes definidos por las leyes generales del país para toda persona: remuneración o recompensa del trabajo, seguridad (que comprende la que afecta al trabajador en su permanencia y facilidad en el trabajo, la seguridad de la existencia digna a través de sistemas de seguros sociales y la protección de la integridad física del trabajador en el lugar de trabajo). Este "estatuto", que deberá comprender aquéllos derechos y deberes debería de constituir a modo de una Magna Carta del Trabajador, directamente situada bajo la directa e inmediata acción de la autoridad del Estado, a fin de asegurar y promover su más estricto cumplimiento. En todo ello su pensamiento se hace coincidir en no poco con la posición jurídico-crítica y reformista propositiva de Anton Menger, "socialista jurídico" que había defendido ya previamente la necesidad de crear un estatuto jurídico-protector de la clase trabajadora como extensión del ámbito de la ciudadanía (posición que Menger reflejara reiteradamente en sus principales obras, "El derecho civil y los pobres", "El derecho al producto íntegro del trabajo" y "El Estado socialista"; todas ellas, por cierto, traducidas al español). No debe tratarse de un mera declaración de derechos, sino de una garantía efectiva: de lo que se trata es de lograr el bienestar positivo, eficaz y práctico, hasta donde la justicia en cada caso lo autorice, de todos los hombres, no de meras declaraciones que, si bien brillantes en su expresión, sean más o menos eficaces a ese objeto. El Estado debe dejar de ser "representación de los elementos sociales predominantes" y establecer una organización jurídica de la sociedad más justa y equilibrada para todos. Cfr. PÉREZ DÍAZ,P.: El contrato de trabajo y la cuestión social, Prólogo de Gumersindo de Azcárate, y dedicatoria al Maestro D.Adolfo A.Buylla, Madrid, Hijos de Reus, Editores-Impresores-Libreros, 1917, cap.I, págs.1 y sigs. No se olvide que Pedro Pérez Día fue uno de los pocos grandes teóricos e introductores del marxismo en España. Aunque desde una lectura economicista del pensamiento de Marx, véase su otra importante obra, El socialismo. Fundamentos del sistema marxista. Valor y trabajo, Madrid, 1910. Su visión es la propia de un cierto determinismo económico (desde el cual la concepción materialista de la historia se traduciría en afirmar que el factor determinante es, en última instancia, la producción y la reproducción de la vida real) que se acoplaría perfectamente con su defensa de un reformismo evolucionista, basado en la descentralización de servicios, la participación de las asociaciones y la apuesta por un sistema de participación en la empresa sobre la base de un contrato de trabajo que devendría en una suerte de contrato de asociación para los fines de la producción. Pero no se olvide que este registro de la historia se corresponde con una más extendida mentalidad de la época que creía en el progreso y en la evolución (vgr., la mayoría de las corrientes positivistas). El evolucionismo formaba parte en gran medida de la cultura entre los dos siglos y en el primer tercio del siglo veinte. Véase MONEREO PÉREZ,J.L.: Fundamentos doctrinales del derecho social en España, Madrid, Trotta, 1996, passim.

${ }^{102}$ Véase, expresamente, POSADA,A.: La reforma constitucional, cit. 
específicamente, como un hombre concreto, socialmente situado. El hombre "concreto" y "situado" atiende a la garantía plena de un derecho a la existencia digna ${ }^{103}$. Ello comportaba una revisión de los esquemas antropológicos y políticos sociales en que se basada el constitucionalismo liberal superando la simple consideración del "ciudadano abstracto" ("hombre abstracto") a través de la contemplación del "ciudadano concreto" ("hombre concreto") atendiendo a su posición específica en las formaciones y grupos sociales donde se desenvuelve su personalidad. En efecto, en su opinión, la persona "debe gozar, por obra del esfuerzo colectivo, de un mínimo de condiciones económica, culturales y jurídicas que le permitan actuar en la vida social con la capacidad mínima suficiente para lograr una existencia digna del hombre, es decir, de un ser que no es un puro medio"104. El hombre sólo es realmente libre si disfruta de las condiciones económicas y culturales mínimas para una vida social digna del hombre, para lo cual corresponde al Derecho la tutela jurídica activa de los más débiles, organizando la solidaridad social en un cuadro de afirmación creciente del sistema de libertades ${ }^{105}$. Ello supone -como exigencia de racionalización ético-jurídicaconjugar al máximo nivel de reconocimiento en el orden jurídico (la Constitución jurídica de la sociedad democrática) el sistema de garantías formales con el sistema de garantías jurídico-materiales o de contenido social. De ahí su propuesta, reflejada en su obra La reforma constitucional, de constitucionalizar los derechos sociales, económicos y culturales con un sentido político-jurídico y un alcance próximo al proceso constituyente que ya se había operado en Alemania en virtud de la Constitución de Weimar que se caracterizó por la extensión de los derechos políticos (v.gr., especialmente para la mujer ${ }^{106}$ ) y la garantía de los derechos de contenido social y económico, lo que permite el pleno desarrollo de la persona en los distintos ámbitos donde se desarrolla su personalidad ${ }^{107}$. Se defiende, de este modo, un cambio de racionalidad jurídica, capaz de superar los límites reguladores e

\footnotetext{
${ }^{103}$ No se olvide que Posada había sido traductor de Anton Menger y ya pudo conocer la defensa de este derecho desde el socialismo jurídico, como se evidencia en su estudio preliminar. Véase MENGER,A.: El Derecho civil y los pobres, trad. A.Posada, y Est.prel., de J.L.Monereo Pérez, Granada, Comares (Colección Crítica del Derecho), 1998. Reflejándose, nuevamente, la impronta constitucional de la ordenación de "lo social", el art.151 de la Constitución de Weimar de 1919, establecía que "la organización de la vida económica debe responder a los principios de justicia y proponerse como fin garantizar a todos una existencia digna del hombre".

${ }^{104}$ POSADA,A.: Teoría social y jurídica del Estado, cit., pág.373.

${ }^{105}$ POSADA,A.: La crisis del Estado y el Derecho político, cit., pág.103; POSADA,A.: La reforma constitucional, cit., pág.136. Véase también AUNÓS PÉREZ,E.: Estudios de Derecho corporativo, Madrid, Reus, 1930, pág.4.

${ }^{106}$ Véase ya anticipadoramente POSADA,A.: Feminismo, Madrid, Librería de Fernando Fe, 1899. (reeditada, POSADA,A.: Feminismo, Madrid, Ed. Cátedra-Principado de Asturias, a cargo de Oliva Blanco, 1994). Krause había defendido los derechos de la mujer y la acción positiva del Estado en favor de la misma. Véase, al respecto, QUEROL FERNÁNDEZ,F.: La filosofía del Derecho de K.Ch.F.Krause, Madrid, Universidad Pontificia Comillas, 2000, págs.310 y sigs. Preocupación que se proyectará también respecto a los derechos sociales de la mujer trabajadora en el marco de la actividad del IRS en el que tan intensamente trabajó. Una perspectiva general sobre el problema puede encontrarse en CAPEL MARTÍNEZ,R.M.: El trabajo y la educación de la mujer en España (1900-1930), Madrid, 1982.

${ }^{107}$ POSADA,A.: La crisis del constitucionalismo, cit., págs.24 y sigs., Ibid., Teoría social y jurídica del Estado, cit., pág.327. Es importante verificar la relevancia político-jurídica de la reforma constitucional. Sobre ella consúltese, VEGA,P.DE.: La reforma constitucional y la Problemática del Poder constituyente, Madrid, Tecnos, 1985; CABO MARTÍN, C.DE.: La reforma constitucional en la perspectiva de las Fuentes del Derecho, Madrid, Trotta, 2003.
} 
integradores del liberalismo posesivo e individualista ${ }^{108}$. El principio-guía (o idea-fuerza) que informa la nueva constitución social del trabajo no deja sombra de duda sobre el giro que de operarse en la lógica jurídica: "No se considerará, ni se tratará, el trabajo humano como una mercancía sometida, sin reservas, a las exigencias de la competencia"109. De ahí la concepción, ya acogida significativamente por el preámbulo de la Constitución de la OIT de que, ante todo, los derechos sociales son derechos de desmercantilización relativa del trabajo profesional ${ }^{110}$. En este sentido los derechos sociales están orientados hacia la realización plena del principio de igualdad.

Ello supone una progresión hacia un paradigma garantista, en la que se conjuga la racionalidad formal y la racionalidad sustancial, donde la legitimidad se obtiene no meramente a través de criterios puramente formales, sino fundamentalmente mediante criterios de carácter sustancial, esto es, su conformidad respecto a los valores constitucionales. Este transición de modelos, del liberal formalista al garantismo jurídico, que atiende a los contenidos es coherente con el pensamiento de Adolfo Posada para el cual la legitimidad estaba condicionada a la conformidad de las normas con el sistema de valores consagrados en la constitución jurídica ${ }^{111}$. El paradigma garantista se cimentada en un Estado constitucional comprometido en la realización de los derechos del hombre o de la personalidad, que comprenden los derechos civiles, los derechos políticos y los derechos sociales, económicos y culturales, que suponen prestaciones públicas positivas ${ }^{112}$. El Estado democrático-social supone la disolución del paradigma jurídico liberal, y se atribuye para sí la función sociointegradora del Derecho. El Estado constitucional moderno se basa en un modelo de juridificación del poder político que comporta una dominación racional orientada funcionalmente hacia la solidaridad social, con la consiguiente expansión de los derechos de

\footnotetext{
${ }^{108}$ Véase MACPPHERSON,C.B.: La teoría política del individualismo posesivo, trad.J.R.Capella,Barcelona, Fontanella,1970, y, más recientemente, sobre sus hombros, BARCELLONA,P.: El individualismo posesivo, trad.M.Maresca, .Trotta, 1996. Sobre esa centralidad en el plano estrictamente político, véase OLIET PALÁ,A.: Liberalismo y democracia en crisis, Madrid, CEC, 1994, espec., págs.48 y sigs.

${ }^{109}$ Base IX ("El trabajo") de su propuesta de Constitución para la segunda república recogida en La reforma constitucional, cit., pág.219-220.

${ }^{110}$ Véase MONEREO PÉREZ,J.L.: Derechos sociales de la ciudadanía y ordenamiento laboral, Madrid, Consejo Económico y Social de España, 1996, págs. 27 y sigs. ("Los modelos de Estados del Bienestar y la desmercantilización como objetivo de la política social moderna"), Capítulo II, págs. 45 y sigs. ("La desmercantilización relativa del trabajo como objetivo de la política social en el capitalismo avanzado: el trabajo y su ordenación jurídica"), Capítulo III ("Estado del Bienestar y ciudadanía: los derechos sociales como derechos de la ciudadanía"), passim.

${ }^{111}$ Ciertamente "el paradigma del Estado constitucional de derecho -o sea, el modelo garantista- no es otra cosa que esta doble sujeción del derecho al derecho, que afecta a ambas dimensiones de todo fenómeno normativo: la vigencia y la validez, la forma y la sustancia, los signos y los significados, la legitimación formal y la legitimación sustancial o, si se quiere, la "racionalidad formal" y la "racionalidad material" weberianas. Gracias a la disociación y a la sujeción de ambas dimensiones a dos tipos de reglas diferentes, ha dejado de ser cierto que la validez del derecho dependa, como lo entendía Kelsen, únicamente de requisitos formales, y que la razón jurídica moderna sea, como creía Weber, sólo una "racionalidad formal"; y también que la misma esté amenazada, como temen muchos teóricos actuales de la crisis, por la inserción en ella de una "racionalidad material" orientada a fines, como lo sería la propia del moderno Estado social". Cfr. FERRAJOLI,L.: Derechos y garantías. La ley del más débil, Madrid, Trotta, 1999, pág.22.

${ }^{112}$ Véase MONEREO PÉREZ,J.L.: Derechos sociales de la ciudadanía y ordenamiento laboral, Madrid, CES, 1996.
} 
la persona o de la ciudadanía en su dimensión más amplia. El Derecho como mecanismo de integración social (de "inclusión") en una sociedad democráticamente constituida ${ }^{113}$, sólo así la constitución jurídica de la comunidad política se asentará duraderamente como orden legítimo en una sociedad cada vez más diferenciada internamente ${ }^{114}$ : una democracia de masas articulada como Estado social de Derecho ${ }^{115}$, con la atribución a los individuos de un status de miembro de la comunidad jurídica que le confiere la condición de sujetos libres e iguales y la exigibilidad jurídica de condiciones de vida dignas. En el nuevo paradigma constitucional garantista la Constitución jurídica es situada en el centro del sistema jurídico, ejerciendo su supremacía y estableciendo el proyecto-programa que ha de guía la vida política y social y la tarea de los poderes públicos. De manera que el poder constitucional se entiende efectivamente como un actuar en común, con voluntad común ${ }^{116}$, y legitimidad como "aceptabilidad racional"117. En esa línea de pensamiento se puede extraer la idea de una democracia deliberativa, basada de una asociación democrática en la que la justificación de las condiciones de asociación se produce mediante la argumentación y el razonamiento público entre ciudadanos iguales ${ }^{118}$. La posición de Posada, en la vejez, se inclina hacia el republicanismo social o liberalismo social, un liberalismo orientado a los derechos y en defensa del Estado social, que se atenga a una distribución justa de los bienes primarios y que parte asimismo de la tolerancia respecto de aquellas doctrinas razonables que no socaven la unidad y la justicia de la sociedad. Tolerancia que parte de un consenso subyacente en la coexistencia pluralidad de las diferencias doctrinas y concepciones del mundo ${ }^{119}$. El liberalismo del Posada defiende un equilibrio e interdependencia entre lo individual y lo social. La libertad abstracta y negativa debe integrarse con la libertad concreta y positiva, de manera que se reconozcan los derechos sociales de los ciudadanos y el papel de las organizaciones profesionales en la negociación colectiva y en la formación de las políticas públicas respecto a compensar o equilibrar la relación de poder asimétricos existente entre el trabajo y el capital, con el efecto de normalizar y moderar el conflicto de clases.

El republicanismo de Posada es también un modelo pluralista en lo político y en el campo social, en el que la sociedad civil no se contempla ya monolíticamente sino vertebrada en agregaciones sociales (fuerzas de intereses organizados como actores colectivos) y dotada

\footnotetext{
${ }^{113}$ Véase HELLER,H.: Teoría del Estado, ed., y Est.prel., a cargo de J.L.Monereo Pérez, Granada, Comares (Colección Crítica del Derecho), 2003; y SMEND,R.: Constitución y Derecho constitucional (1928), en Constitución y Derecho constitucional, Madrid, Centro de Estudios Constitucionales, 1985.

${ }^{114}$ Véase WEBER,M.: Sociología del Derecho, Ed. y Est.prel., a cargo de J.L.Monereo Pérez, Granada, Comares (Colección Crítica del Derecho), 2001.

${ }^{115}$ Véase EWALD,F.: L'État Providence, París, Grasset, 1986.

${ }^{116}$ Cfr.ARENDT,H.: La condición humana, Barcelona, Paidós, 1993, págs.223 y sigs.

${ }^{117}$ Cfr.AARNIO,A.: Lo racional como razonable, Madrid, CEC, 1991, págs.83 y sigs.

${ }^{118}$ En este sentido HABERMAS,J.: Facticidad y validez,trad.M.Jiménez Redondo, Madrid, Trotta, 1998, pág.381, con referencia a COHEN,J.: "Deliberation and Democratic Legitimacy", en HAMLIN,A.y PETTIT,B.(eds.): The Good Polity, Oxford, 1989, págs.17 y sigs. Más ampliamente sobre esta cuestión, COHEN,J.L.,y ARATO,A.: Sociedad civil y teoría política, México, FCE, 2000, passim.

${ }^{119}$ Para el debate actual sobre el liberalismo político, véase HABERMAS,J.y RAWLS,J.: Debate sobre el liberalismo político, Introducción de F.Vallespín, Barcelona, Paidós, 1998. Me permito remitir a mi Estudio preliminar a KELSEN,H.: Esencia y valor de la democracia, edición y estudio preliminar a cargo de J.L. Monereo Pérez, Granada, Comares (Colección Crítica del Derecho), 2002.
} 
de espacios autónomos de gran vitalidad. Es así que para él la sociedad civil viene constituida por una trama asociativa expresan la constelación de problemas que se perciben la sociedad complejamente estructurada. El republicanismo social de Posada rechaza la idea estatalista de una dominación completa del Estado sobre la sociedad, pero, marcando diferencias con el liberalismo clásico, se muestra partidario de limitar la autonomía sistemática de la esfera económica, porque es necesario consagrar derechos sociales que en cuenta tales son "derechos de desmercantilización" ${ }^{120}$, siquiera sea relativa, respecto la regulación inmanente del "mercado" como espacio de toma de decisiones por agentes influyentes sobre el bienestar. Es aquí donde aparece -y hay que rendir tributo- a Adolfo Posada como teórico y práctico de la política social contemporánea y de los derechos sociales de la ciudadanía, en un momento donde no se había producido todavía la importante aportación de autores como T.H. Marshall ${ }^{121}$, y en sintonía con el ámbito de revisión que se estaba produciendo a través de las contribuciones fundamentales de los iusocialistas (Menger, ante todo, Salvioli, Consentini, Cimbali...; Radbruch, Sinzheimer, Renner, Heller...) y los socialistas fabianos (los esposos Webbs, el primer Laski, G.D.H. Cole...), el solidarismo jurídico (Alfred Fouillée, Léon Bourgeois y Duguit en la estela de Durkheim...), la doctrina del derecho social de Gierke, desde el organicismo historicista y ético, el institucionalismo pluralista de Gurvitch (su obra principal se publicó en 1932), al cual si alcanzó a acceder Posada en su vejez. Posada había percibido el cambio de paradigma liberal hacia el paradigma del garantismo constitucional de los derechos en el marco del Estado social. Se opera una alteración del modelo de regulación de los derechos, toda vez que -como gráficamente señalaría T.H.Marshall- los derechos sociales en su forma moderna suponen una invasión del contrato por el estatus, la subordinación del precio de mercado a la justicia social, la sustitución de la libre negociación por la declaración de derechos ${ }^{122}$. De lo que se trata es de garantizar el derecho del individuo a un nivel mínimo de vida civilizada, que es lo que precisamente defendiera Anton Menger en tres de sus obras fundamentales (El derecho civil y los pobres, El derecho al producto íntegro del trabajo y El Estado socialista). La realización de estos derechos -su eficacia social- supone una política social encaminada a organizar las prestaciones y los servicios sociales correspondientes, la redistribución de las rentas, y más ampliamente a articular una intervención pública sistemática en todos los

\footnotetext{
${ }^{120}$ Esta idea de los derechos sociales como derechos de desmercantilización, en MONEREO PÉREZ,J.L.: "Los derechos sociales como derechos de desmercantilización", en Revista de Trabajo, 1995; MONEREO PÉREZ,J.L.: Derechos sociales de la ciudadanía y ordenamiento, Madrid, CES, 1996. Su garantía en la forma política del Estado social estaría llamada a resolver la contradicción existente entre el reconocimiento de un régimen de sufragio universal y un Estado no garante de posiciones desmercantilizadoras (y por consiguiente limitativas) del mercado.

${ }^{121} \mathrm{Su}$ ensayo fundamental data de 1950, MARSHALL,T.H.: Ciudadanía y clase social (1950), en MARSHALL,T.H.y BOTTOMORE,T.: Ciudadanía y clase social, Madrid, Alianza, 1998.

${ }^{122}$ MARSHALL,T.H.: Ciudadanía y clase social (1950), cit., pág.69. Idea presente, de modo señalado, en la tendencia del "socialismo jurídico", como puede comprobarse, por ejemplo, en COSENTINI,F.: La reforma de la legislación civil y el proletariado, Est.prel., de Gumersindo de Azcárate e Introducción de Giuseppe Salvioli, versión castellana por Alberto Aguilera y Arjona, Madrid, Francisco Beltrán, 1921, págs.191 y sigs., donde matiza el proceso de transición del status al contrato que había sido formulada por Maine, condicionado históricamente por un período de liberación de las trabas del antiguo régimen.
} 
ámbitos del ciclo de reproducción de la vida social, con la finalidad de cambiar y reformar la estructura desigual de la sociedad moderna ${ }^{123}$.

El nuevo paradigma garantista (que abunda en el constitucionalismo, instituyente de un orden superior al de los poderes por ella constituidos) supone, pues, una nueva forma de Estado, el Estado social, que se sitúa en un punto medio entre el individualismo liberal y el socialismo a través de una organización jurídico-política del capitalismo ("capitalismo organizado"), y de aceptación de reglas de juego que reflejan un compromiso de clase ${ }^{124}$. El nuevo "programa" supera las previsiones y los esquemas doctrinarios del liberalismo clásico, especialmente la aceptación del principio de soberanía popular (y no su absorción en la soberanía del Estado) y la necesidad de un Derecho social para afrontar los problemas planteados por la llamada "cuestión social"125. El cambio está enmarcado en el proceso de modernización (vinculado a la revolución industrial, a la ideología liberal, y más tarde a las revoluciones liberales) y en la dinámica de los conflictos sociales. El tránsito del Estado liberal de derecho al Estado democrático o liberal democrático de derecho, se opera con el reconocimiento del sufragio universal y el derecho de asociación ${ }^{126}$. Con la democratización del liberalismo originario se trataba de legalizar a la clase trabajadora integrándola en el orden establecido ${ }^{127}$. El proceso de democratización constituye un factor de legitimación del sistema político, devenido ahora en Estado liberal democrático. La defensa del sufragio en

\footnotetext{
${ }^{123}$ Adviértase en la noción amplia de política social de Posada, en POSADA,A.: "Política social y Legislación del trabajo", en Derecho usual, Madrid, Ediciones de la Lectura, s/f., págs.489 y sigs.

${ }^{124} \mathrm{Me}$ permito remitir a MONEREO PÉREZ, J.L.: La organización jurídico-económica del capitalismo. El Derecho de la economía, al libro extraordinario de RIPERT,G.: Aspectos jurídicos del capitalismo moderno, trad.J.Quero Morales, Granada, Ed.Comares (Colección Crítica del Derecho), 2001, págs. XIII-CL.; RIPERT, G.: El régimen democrático y el derecho civil moderno, trad. José M. Cajica Jr., revisión, edición y estudio preliminar, "Derecho privado y democracia constitucional: Georges Ripert, ¿Paradigma de jurista liberal?", a cargo de J.L. Monereo Pérez, Granada, Comares (Colección Crítica del Derecho), 2021.

OFFE,CL.: Contradicciones en el Estado del Bienestar, Madrid, Alianza editorial, 1990; MUÑOZ DE BUSTILLO,R.(ed.).: El Estado de Bienestar en el cambio de siglo, Madrid, Alianza editorial, 2000.

${ }^{125}$ Véase POSADA,A.: "El derecho y la cuestión social", Est.prel., a MENGER,A.: El Derecho civil y los pobres, Madrid, Lib.Gral. de Victoriano Suárez, 1898, reeditada por Comares (Colección Crítica del Derecho), con estudio preliminar a cargo de J.L. Monereo Pérez, Granada,1998.

${ }^{126}$ Sobre el reconocimiento del derecho de asociación en España, véase ZANCADA,P.: Derecho corporativo Español. Organización del Trabajo, Madrid, Librería de Juan Ortiz Editor, s/f., caps.V, VI y VII; ALARCÓN CARACUEL,M.R.: El derecho de asociación obrera en España (1839-1900), Madrid, Revista de Trabajo, 1975; YVORRA,J.A.: Los orígenes del derecho de asociación laboral en España, Valencia, Tip.Pascual Ibañez, 1978; OLÍAS DE LIMA GETE,B.: La libertad de asociación en España (1868-1974), Madrid, Instituto de Estudios Administrativos, 1977; IZARD,M.: Industrialización y Obrerismo. Las Tres Clases de Vapor (1869-1913), Barcelona, Ariel, 1973; ELORZA,A.: "Los orígenes del asociacionismo obrero en España", en Revista de Trabajo, núm.41 y 42 (1973).

${ }^{127}$ Se observó que con el sufragio los trabajadores tiene un arma importante, y "es más. La igualdad política que poseen les impulsa á reclamar la igualdad económica. En vano los economistas celebran cándidamente la muerte del socialismo; inútil será que durante algún tiempo esté de moda entre sus detractores el anunciar su bancarrota á cada obstáculo que halla en su camino. Su idea fundamental, á saber, que la socialización de los medios de producción es indispensable para resolver la cuestión social, queda anclada en el fondo de las conciencias obreras y esto es bastante para que la segunda mitad del siglo XIX ofrezca un carácter completamente distinto del de la primera; para que la acción legislativa como la iniciativa privada, modifique profundamente el régimen industrial". Cfr. RENARD,G.: Sindicatos y Trade-unions y Corporaciones, trad., aumentada con un prólogo, un apéndice bibliográfico sobre "El movimiento obrero español", por Manuel Nuñez de Arenas, Madrid, Daniel Jorro, Editor, 1916, págs.306-307 (Reditada con estudio preliminar a cargo de J.L. Monereo Pérez, Granada, Editorial Comares (Col. Crítica del Derecho), 2014).
} 
la perspectiva del organicismo corporativista había sido defendida por Adolfo Posada, entiendo que el sufragio refleja la unión del individuo con el Estado y su configuración como función y deber social ${ }^{128}$.

Del liberalismo clásico se pasa al "liberalismo democrático" o Estado liberal-democrático ${ }^{129}$ (y es justo señalar que éste fue siempre punto de partida en la cosmovisión de Posada, que trató desde su juventud democratizar el liberalismo) y, desde este, al "liberalismo social" o "republicanismo democrático-social" que es el que mantendría inequívocamente en el periodo de mayor plenitud intelectual, ya en el marco de su compromiso ético (muy anterior) y administrativo-institucional (su presencia "interna" en el IRS) con la reforma social. La extensión de los derechos de ciudadanía política (voto y asociación) y el reconocimiento de los derechos sociales, económicos y culturales daba respecto a la insuficiencia de la igualdad formal como elemento de la cuestión social, y la necesidad de completarla a través de una igualdad material ${ }^{130}$. Es a partir de la primera posguerra mundial cuando el proceso de democratización incorpora formalmente una dimensión sociopolítica. El fenómeno se conecta con la dotación de contenido material al principio de igualdad y a la imputación al Estado democrático de deberes de actuación positiva para garantizarlo y con él para hacer efectiva la libertad. El proceso de reforma política se puede simplificar en los mismos términos expresivos que ya aportar Adolfo Posada: la fórmula del Estado democrático y liberal social de Derecho, que es una proyección, en Posada, de los principios del republicanismo social o liberalismo social, esto es, un liberalismo corregido. Se produce un cambio de paradigma: del paradigma liberal clásico (Estado liberal de derecho) se transita hacia el paradigma social garantista (Estado social de derecho).

De este modo, el sistema político democrático inserta una dimensión social que supone una intervención pública permanente en la generación y distribución del bienestar. El Estado liberal social (que se asienta en un pacto político social subyacente) pero con una marcada orientación organicista, es el defendería el último Posada. Esta forma de Estado social

128 POSADA, A.: El sufragio según las teorías filosóficas y las principales legislaciones, Barcelona, Sucesores de Manuel Soler-Editores,Vol. XII de la Colección de Manuales Publicados, 1900, espec., págs.12 y sigs. ("Noción de sufragio"), 26 y sigs. "La representación política y el sufragio"), y 152 y sigs. ("La representación corporativa y de intereses"). Defendía ya Posada la doctrina orgánica del Estado y la función del sufragio: "Por este lado, la representación de los intereses debe ser rectificada y completada con la concepción orgánica del Estado, la cual ve en éste, no una suma de individuos, sino un conjunto de personas individuales y colectivas, considerando, en su consecuencia, que no puede estimarse la voluntad del Estado como la simple suma de voluntades de un cuerpo electoral, por amplio que éste se conciba. En Ahrens, en Mohl, y sobre todo en Krause y su escuela, especialmente en España, se ha afirmado el carácter compuesto, verdaderamente orgánico, es decir, vivo y complejo, de la sociedad y del Estado, en los cuales hay de un lado individuos, seres políticos, ciudadanos, cuya acción en el Estado es evidente, y de otro, corporaciones, entidades, colectividades, constituidas para reflejar de una manera más intensiva y complicada, los distintos fines de la vida" (Ibid., págs. 154-155). En esa misma dirección afirmativa se abunda en el apartado siguiente dedicado a "la representación de los intereses, la representación corporativa y el sufragio individual” (Ibid., págs. 155-156).

${ }^{129}$ Para el sentido técnico y político jurídico de esta fórmula del "Estado liberal-democrático", puede consultarse POGGI,G.: Lo Stato. Natura, sviluppo, prospettive, Bologna, Il Mulino, 1992, caps. VII y VIII, págs.163 y sigs., y 193 y sigs., respectivamente.

${ }^{130}$ Véase MANENT,P.: Historia del liberalismo (la versión francesa es más expresiva de su orientación, Histoire intellectuelle du libéralisme, París, Calmann-Lévy, 1987), Buenos Aires, Emecé, 1990. 
incorpora una doble racionalidad: la racionalidad formal y la racionalidad material, estando en ésta presente la tensión permanente entre la "razón social" (principio axial jurídico de protección social, que impulsa cierto nivel de desmercantilización) y la "razón económica" (principio axial jurídico-económico de rendimiento y eficiencia económica, que impulsa hacia la mayor mercantilización). En ese punto de equilibrio principialista se sitúa el Derecho social del trabajo, respecto al cual las constituciones contemporáneas imponen en todo caso un nivel mínimo de protección social desmercantilizadora a fin de garantizar al individuo un nivel de vida digno. Reténgase aquí la relevancia que para Posada tenía el reconocimiento de los derechos sociales de la ciudadanía y en particular del derecho a la existencia digna ${ }^{131}$.

La revisión o rectificación del liberalismo hizo posible la integración de la clase trabajadora en la dinámica político institucional del sistema establecido; y lo hizo a través de un doble movimiento de extensión de los principios liberales: el principio de representación que se amplía a los intereses de la clase trabajadora y el principio de contrapoder, con el reconocimiento de las organizaciones profesionales y de sus medios de acción colectiva. La creación del Derecho social como nuevo proceso de sectorialización del sistema jurídico, introduce una fractura interna en la pretensión de universalidad y abstracción de la ley estatal, porque precisamente ese Derecho social se basó primero en una legislación excepcional y asistemática desviante respecto de los principios radicalmente individualistas que informaban el sistema del liberalismo clásico, y que reviste el carácter de concesión a los débiles que es interés del Estado reconocer como prolongación del pasado mediante la pervivencia del orden fundamental; $y$, después, a través como derecho especial cuyo principios son directamente recibidos de la Constitución en su calidad de norma fundamental del ordenamiento jurídico general, y cuyo sistema de fuentes se nuclea entorno a la doble presencia del poder normativo público y de la autonomía privada colectiva (la negociación colectiva). Todo este enfoque marca verdaderamente una ruptura respecto al paradigma del liberalismo clásico e introduce nuevos elementos en el discurso de la modernidad. Posada no sólo se inserta en esa corriente de revisión del liberalismo individualista, sino que participa decisivamente en la elaboración de los fundamentos doctrinales en que aquélla se basó.

En una perspectiva próxima a la que planteara en su momento Posada se ha hablado contemporáneamente de la dignidad humana como "premisa antropológico-cultural" del Estado constitucional y la democracia "como consecuencia organizativa de la dignidad humana"132. El individuo tiene derecho al libre desarrollo de su personalidad, y en esa

\footnotetext{
${ }^{131} \mathrm{El}$ derecho a una existencia digna había sido defendido por Krause y por Menger. Sobre la posición de krause, véase QUEROL FERNÁNDEZ,F.: La filosofía del Derecho de K.Ch.F.Krause, Madrid, Universidad Pontificia Comillas, 2000, pág.375 y sigs., el cual hace notar que Krause considera necesaria la intervención pública del mercado, en coherencia con su compromiso con la realización del contenido de la libertad le conducirá a legitimar el papel de las instituciones públicas en el control y regulación del mercado.

${ }^{132}$ Para este planteamiento, véase HÄBERLE,P.: El Estado constitucional, Est.introductorio de D.Valdés, México, UNAM, 2001 (reeditada por la Editorial Comares (Col. Crítica del Derecho), edición al cuidado de J.L. Monereo Pérez, Granada).
} 
garantía de ser persona encuentra la dignidad humana una posición central en el Estado constitucional, el cual realiza la dignidad humana haciendo a los ciudadanos sujetos de su actuación. En este sentido se ha afirmado, acertadamente, que existe una íntima vinculación entre la dignidad humana y la democracia, siendo doble el fundamento del Estado constitucional: la soberanía del pueblo y la dignidad humana ${ }^{133}$. Su garantía ha determinado una progresiva constitucionalización de los derechos humanos. Hasta tal punto es así que la democracia aparece "como consecuencia organizativa de la dignidad humana"134. Este enfoque antropológico es desde luego especialmente próximo a Adolfo Posada, y es preciso reconocer que a la corriente del liberalismo progresista del krausismo español, que convertía al individuo y al desarrollo de su personalidad en el epicentro de todo el sistema jurídico. Y es que la fórmula "Estado social de derecho" significa que el Estado constitucional está comprometido con la justicia social y, entre otras cosas, remite a un estándar común de derechos humanos garantizados jurídicamente al máximo nivel ${ }^{135}$. La misma garantía de un mínimo existencial se ha fundado en el principio del Estado social.

Toda esta exposición de su pensamiento pone de relieve que Posada creía en los valores de la democracia, aunque su pensamiento no estuviere libre de contradicciones. Éstas en gran medida vinculada con una cierta concepción elitista de la democracia, la que, por lo demás, era bastante generalizada en los intelectuales "orgánicos" de su época. Era el miedo realmente sentido a la "rebelión de las masas" (presente en la tradición de Mosca, Pareto, Ortega y Gasset, hasta contemporáneamente Giovanni Sartori), y el entendimiento -más extendido de lo que comúnmente se piensa, y se "reconoce" sinceramente- de que la clave de la supervivencia de la democracia queda en manos de la élite gobernante, élite cuyo poder se fundamenta en el reconocimiento de su superioridad. También la convicción, coherente con lo dicho, de que una función esencial de la élite política e intelectual es frenar a las masas, impidiéndoles caer en la tentación de las transformaciones radicales e impuestas de manera violenta. De este modo la concepción elitista de la democracia ("elitismo democrático") no rechaza el pluralismo y trata -se piensa- de proteger contra la rebelión de las masas ${ }^{136}$. Es así que su concepción de la democracia como "democracia orgánica" no aparece en el esquema de su pensamiento (más allá de no atendibles convergencias exclusivamente etimológicas) como contrapuesta a la esencia y valor de la democracia ${ }^{137}$, incorporando, además, elementos sustanciales vinculados a los principios de igualdad y solidaridad social.

\footnotetext{
${ }^{133}$ HÄBERLE,P.: El Estado constitucional, Est.introductorio de D.Valdés, México, UNAM, 2001, pág.172.

${ }^{134}$ HÄBERLE,P.: El Estado constitucional, cit., pág.193.

${ }^{135}$ HÄBERLE,P.: El Estado constitucional, cit.,pág. 225.

${ }^{136}$ Un planteamiento crítico, al respecto, en BACHRACH,P.: Crítica de la teoría elitista de la democracia, Buenos Aires, Amorrortu editores, 1973. Me he ocupado de estas cuestiones en MONEREO PÉREZ,J.L.: "Estado y democracia en Otto Kirchheimer", Est. prel., a KIRCHHEIMER,O.: Justicia política. Empleo del procedimiento legal para fines políticos, Granada, Comares, 2001.

${ }^{137}$ En el sentido, por ejemplo, de KELSEN,H.: Esencia y valor de la democracia, trad. R.Luengo Tapia y L.Legaz Lacambra, y edición y Est.prel., a cargo de J.L. Monereo Pérez, 2002. Al respecto, exhaustivamente, MONEREO PÉREZ, J.L.: Los fundamentos de la democracia. La teoría político jurídica de Hans Kelsen, Barcelona, Ediciones de Intervención Cultural/El Viejo Topo, 2013, espec., págs. 87 y sigs., y 103 y sigs.
} 
En este orden de ideas es como conviene afrontar la problemática concepción de un tema fundamental: el sufragio. El sufragio permite formar la representación política general. Pero junto a los individuos existen intereses particulares cuya expresión en el seno del Estado ha de ser también garantizada. Dentro de su concepción organicista se detecta que las sociedades están fragmentadas y que ha de tenderse hacia una "democracia orgánica y jerarquizada" que dé cuenta del pluralismo de los intereses organizados o corporativos ${ }^{138}$. Posada quería completar el sufragio universal o "inorgánico" con el sufragio "orgánico". Posada, aunque con ciertos titubeos propios de la tradición elitista del krausismo, defendió la democracia liberal, y su democracia orgánica no pretendía ser una alternativa encaminada a sustituirla. La jerarquización que postula no es de reserva de la democracia a minorías ilustradas, sino más bien el reconocimiento espontáneo por parte de los más, del mejor criterio de los menos, pero mejores, pero en general la "jerarquización" espontánea queda encomendada más bien a la acción educadora, psicológica, que es para él, como fiel krausista, el único instrumento real del cambio social"139. La democracia orgánica se conseguiría para él a través de una reforma institucional del sistema parlamentario, que estableciera un sistema bicameral: una Cámara de representación política general, donde según él prima el elemento individual, y otra Cámara de representación de intereses organizados, donde se toma en consideración el elemento social, el pluralismo de las agrupaciones en las que se estructura internamente una sociedad compleja. Esta reflexión se realizaba en un período de revisión de los fundamentos de la representación. Dos fundamentos sirven a su construcción en favor de la creación de este sistema bicameral: en primer lugar, su ideario krausista que configura orgánicamente la sociedad vertebrada ésta en personas individuales y personas sociales que se organizan dentro de la sociedad estatalmente organizada y que han de encontrarse adecuadamente representadas como tales en el Estado político; y en segundo lugar, la oportunidad histórica, se diría que coyuntural, de que esta forma de representación de intereses podría contribuir decisivamente en la integración y armonización entre los grupos de intereses organizados que emergen en la sociedades del capitalismo desarrollado ${ }^{140}$. Lo que plantea, pues, es la revisión de los

\footnotetext{
${ }^{138}$ Posada no propuso que una reforma encaminada a sustituir la "democracia inorgánica y gregaria" por una suerte de democracia "orgánica y jerarquizada", porque aunque hay un margen de ambigüedad en sus propuestas -no exentas de contradicciones- en el fondo siempre vio como complementarias las instancias de representación política general y las instancias de representación de intereses o corporativa. Prueba de ello son sus "Bases para la Constitución política de España", incluida como Apéndice, y fundamentada en el texto, de su obra La reforma constitucional, cit.

${ }^{139}$ RUBIO LLORENTE,F.: "Estudio preliminar" a la obra de POSADA,A.: Estudios sobre el Régimen Parlamentario en España, Oviedo, Junta General del Principado de Asturias, 1996, pág.LXXIX.

${ }^{140}$ POSADA,A.: La reforma constitucional, cit., págs.104 y sigs., y el "Apéndice sobre las "Bases para una Constitución política de España"; La crisis del Estado, cit., págs.139 a 143; La nueva orientación del Derecho político, cit., págs.337 y sigs. Su propuesta no estaba aislada, entroncaba -y en gran medida obedecía- a un sentir de la época de entreguerras que había venido produciéndose desde diversas corrientes de pensamiento, especialmente el llamado "socialismo fabiano" y el "socialismo gremial", con figuras señeras como los esposos Webb (que había defendido la instauración de un "parlamento social" junto al "parlamento político"), y el primer Laski, que defendiera la creación de una cámara profesional complementaria de la cámara de representación política general. Véase MONEREO PÉREZ,J.L.: La filosofía política de Harold J.Laski, Est. prel., a la obra de LASKI,H.J.: La Gramática de la Política. El Estado moderno, Granada, Comares (Colección Crítica del Derecho), 2002, págs. XV-C.; MONEREO PÉREZ, J.L.: La democracia en crisis: Harold J.Laski, Barcelona, Ediciones de Intervención Cultural/El Viejo Topo, 2004.; LASKI, H.J.: Democracy in Crisis
} 
fundamentos de la representación política, entre otras cosas, hacia la representación de los intereses en el régimen político y la consiguiente constitucionalización de la representación política de los intereses sociales distinguiendo -en régimen de coexistencia y complementariedad- entre representación política y representación social y su materialización en dos Cámaras del Parlamento ${ }^{141}$.

En el pensamiento de Posada la Cámara profesional o parlamento funcional estaría subordinada a la Cámara de representación política general como expresión de la sociedad total. Su "liberalismo organicista" quiere seguir siendo democrático, ser una solución superadora de la crisis del parlamentarismo. La Cámara corporativa era una proyección de la orientación organicista inherente al krausopositivismo que profesa Posada. De ahí su desaprobación de la régimen unicameral consagrado en la Constitución republica de 1931, como se refleja en sus obra posteriores a la proclamación de la II República. Posada había entendida, como otras personalidades de su generación, que el sistema bicameral ${ }^{142}$, con cámara profesional o corporativa, permitiría domesticar la luchas de clases (encauzarla política y jurídicamente) en la línea íntimamente sentida de suprimir los conflictos mediante su integración en el nuevo orden institucional postliberal individualista. Permitiría igualmente resolver la crisis del parlamentarismo liberal desde la lógica de un organicismo democrático. Su opción se insertaba en el reformismo político y social, de carácter armónico

(1933), Chapel Hill, University of North Carolina Press. Trad.esp., La democracia en crisis, trad.V.Herrero Ayllón, Madrid, Edersa,1934. MONEREO PÉREZ, J.L: La crisis de la Socialdemocracia Europea. Eduard Bernstein y las premisa del socialismo reformista, Barcelona, Ediciones de Intervención Cultural/El Viejo Topo, 2012.

${ }^{141}$ POSADA,A.: La reforma constitucional, cit., Capítulo V, págs. 104 y sigs., en particular págs. 138 y sigs. ("Representación política y representación social.-Las Cámaras del Parlamento"). La solución corporativa democrática en las relaciones laborales, en la Base IX ("El trabajo"), apartado i), a cuyo tenor: "Se regularán jurídicamente las relaciones entre patronos y obreros, en interés de la producción y de la armonía social, mediante la organización general corporativa de las profesiones y oficios en las distintas industrias, convenientemente acomodada a las exigencias geográficas de la vida nacional y local. En las corporaciones que se constituyan funcionarán representaciones de los factores de la producción, con competencia para discutir las condiciones generales de la industria representada, acordar los convenios colectivos de normas aplicables a las distintas clases de trabajo, y para prevenir y, en su caso, resolver conflictos de carácter colectivo que puedan suscitarse entre patronos y obreros, así como para determinar la intervención que en la vida de la industria pueda atribuirse al elemento trabajador en ella interesado". De este modo, postula una especie de democracia industrial de signo corporativista.

En el régimen parlamentario, la Base XIX ("El Senado"), estructurado con representaciones de las corporaciones, Cámaras y asociaciones profesionales. En el gobierno de la economía, la Base XXVI ("Funciones del Gobierno"), apartado 3: "Se organizará un Instituto Nacional de Economía y de Reformas Sociales, encargado especialmente de asesorar al Gobierno en la preparación de los proyectos de carácter económico y social, y el cual funcionará como un servicio descentralizado. Formarán este Instituto: $1^{\circ}$. Representaciones directas de las Asociaciones Patronales y obreras. $2^{\circ}$. Representaciones de las Instituciones y Corporaciones constituidas para la defensa de los intereses económicos y sociales. 3...". En realidad, aquí más que apostar por el corporativismo propiamente dicho, Posada anticipa la institución de los Consejos Económicos y Sociales.

${ }^{142}$ En los años veinte se había producido una extensión del pensamiento organicista, que ya encontrara apoyos en la doctrina. La defensa del organicismo era extensible a distintas corrientes de pensamiento, y encontraba un fuerte arraigo en el krausismo con Giner (especialmente en su obra La persona social), Azcárate y Posada, que postulaba con base a ese organicismo social un sistema de representación política orgánica de los intereses. Véase en una perspectiva de conjunto, GARCÍA CANALES,M.: La teoría de la representación en la España del siglo XX, Murcia, Universidad de Murcia, 1977, págs.25 y sigs. 
e integrador. Y es oportuno precisar esto porque la propuesta de una representación de intereses se ha realizado desde distintas posiciones políticas e ideológicas y para fines completamente diferentes ${ }^{143}$; y es harto significativo que a finales de la década de los veinte y en plena "Dictablanda" de Primo de Rivera (Gobierno de Dámaso Berenguer) las organizaciones de intereses económicos empresariales reivindicaran la creación de un "Parlamento del Trabajo"144. En el período se constataba un fuerte movimiento de opinión a favor de la instauración de mecanismos de representación profesional ${ }^{145}$.

Pero a diferencia de la orientación del socialismo gremial y fabiano (contrario a un modelo de socialismo de Estado burocrático $)^{146}$ que había influido notoriamente en socialistas españoles de tradición krausista organicista como Julián Besteiro ${ }^{147}$ y Fernando de los Ríos, Posada (muy influido por el pensamiento de León Duguit) -e incluso del "socialismo científico/jurídico orientado hacia la reforma social ${ }^{148}$ - no llegó a enmarcar esta propuesta

\footnotetext{
${ }^{143}$ Véase la exposición de ESTEBAN,J.: La representation des intérêts et son influence en France, Tesis doctoral inédita, Parías, 1967: ID.: "La representación de intereses y su institucionalización", en REP, núm.155 (1967), págs.51 y sigs; Para la problemática actual, véase PÉREZ YRUELA,M.y GINER,S.(Eds.).: El corporativismo en España, Barcelona, Ariel, 1988, donde se recoge una importante aportación de LINZ,J.J.: "Política e intereses a lo largo de un siglo en España", 1880-1980", págs.67 y sigs.; MONEREO PÉREZ,J.L.: Concertación y diálogo social, Valladolid, Lex Nova, 1999.

${ }^{144}$ En este sentido el Escrito de la Cámara Oficial de Industria de Barcelona al Presidente del Directorio Militar el día 25 de septiembre de 1923, A.H.N.,Presidencia del Gobierno, Legajo 459. Véase ZANCADA Y RUATAMO,P.: Derecho Corporativo español, Madrid, 1928, págs.144 y sigs.; GUAL VILLALBÍ,P.: El pensamiento de las clases productoras ante el futuro político de España, Madrid, 1928, págs.408-409.

${ }^{145}$ Véase HAURIOU,M.: Principios de Derecho público y constitucional, trad., estudio preliminar, notas y adiciones por Carlos Ruiz del Castillo, edición al cuidado de J.L. Monereo Pérez, Granada, Comares, 2003, págs.512 y sigs., que subraya el hecho de que puede distinguirse entre dos tendencias distintas: $1^{\circ}$. La representación profesional, desde el punto de vista de la reglamentación de los intereses de la profesión únicamente; $2^{\circ}$, la representación profesional en cuanto reclama la participación en el poder político para el gobierno general del Estado. En tal sentido entiende que es mucho más fácil y seguro conservar la presente base territorial del sufragio, cerrando el camino a la representación políica profesional. La mejor cooperativa de consumidores es todavía el Estado mismo. Su valoración es más prudente respecto a la posibilidad de elegir algunos miembros de las Asambleas políticas por el sufragio profesional a título de agregación de capacidades. Es éste, piensa, un modo de enfocar la representación profesional, que acaso sea también el verdadero. Consiste en considerarla como un medio empírico de renovar parcialmente el personal político, infundiéndole, a intervalos, algunas competencias (Ibid., págs.512 y sigs.).

${ }^{146}$ Véase DOLLEANS,E.: Historia del movimiento obrero, vol.II (1871-1920), trad.D.Abad de Santillán, Madrid, ZYX, 1969, pág.270.; GONZÁLEZ-ESTEFANI ROBLES,J.M.: Essai sur les mouvements sociaux contemporaines: le socialisme humaniste (1800-1965), Madrid, 1967.

${ }^{147}$ Para el pensamiento sociopolítico de Besteiro es obligado remitir a la excelente monografía de LAMO DE ESPINOSA,E.y CONTRERAS,M.: Política y filosofía en Julián Besteiro, $2^{\mathrm{a}}$ ed., corregida y aumentada, Madrid, Sistema, 1990, espec., cap.IV ("El Estado y la Sociedad").

${ }^{148}$ Es el caso de Pedro Pérez Díaz. Para él, el problema social de base exige seguir la senda de un "camino ideal" para la necesaria reforma, de mejora, de paz y tranquilidad para el desarrollo, noble y paciente de todos sus intereses. En este sentido el "contrato colectivo de trabajo" y la intervención estatal pueden actuar como medio de transición entre el actual y el nuevo régimen. Se trataría, reconocida la necesidad y legitimidad del cambio social, de la reforma y mejora de las instituciones, para transformar lentamente el orden social, sin grandes violencias y quebrantos. Él considera necesario "partir de las actuales instituciones económico-jurídicas para transformar el régimen burgués" en un sentido socialista. Para ello él proponía la creación de asociaciones de trabajadores por oficios sobre la base del rendimiento de la jornada voluntaria. Su propuesta, en cierto modo, se asemejaría en esto último, a la propuesta por el "socialismo gremial" inglés. En tal sentido, precisa que su propuesta no tiene carácter de cooperativa de mano de obra, sino de cooperativa socialista por aspirar a crear con ella propiedad de clase social y tender a la mejora individual de los trabajadores, pero a través del capital social o de clase. De este modo la reforma social permitiría un cambio gradual del régimen actual, eludiendo la
} 
como un cauce de democratización económica que permitiera la participación democrática del trabajo en la vida económica, yendo así más lejos de la tradicional visión de la democracia liberal ${ }^{149}$; aunque no descuidó enteramente esta problemática y reivindicó el reconocimiento de derechos de participación de los trabajadores en la vida económica ${ }^{150}$. No obstante, estaba presente en él en términos más amplios la idea de una democratización del Estado liberal a través del sistema bicameral ${ }^{151}$. Desde esta perspectiva, de corporativismo democrático sí se podría hablar de una democracia económica de tipo corporativo-institucional. Quizás en él estuviera más presente la idea defensiva ${ }^{152}$ de contención de los conflictos sociales a través del diálogo y la participación institucional de los distintos agentes sociales y económicos ${ }^{153}$. Desde luego Posada no tenía ni la más mínima inclinación a la instauración de un régimen postliberal de tipo socialista. Posada estaba seguramente más próximo a la inquietud planteada por Melquíades Álvarez respeto a la necesidad de normalizar "lo social" más allá de la perspectiva agotada de pura "cuestión social" excepcional y de orden público. Era necesario integrar a la clase trabajadora y a sus organizaciones sindicales a través de una política de integración en la dinámica político-

solución revolucionaria, innecesaria e inviable. Es el camino lento hacia una verdadera revolución social, por lo demás las mismas revoluciones políticas son siempre sociales, que con frecuencia parezca no afectar más que a las distintas posibilidades que un mismo régimen político pueda ofrecer; pero lo político es siempre el modo de ser de lo social, es su estructura general. El modo de solución del problema social, el ambiente dentro del cual este problema puede resolverse, no es más que por la asociación de los trabajadores, por las asociaciones que ellos creen y que haga posible el contrato colectivo de trabajo. Cfr. PÉREZ DÍAZ,P.: El contrato de trabajo y la cuestión social, Madrid, Hijos de Reus, Editores-Impresores-Libreros, 1917, con Prólogo de Gumersindo de Azcárate, y con dedicatoria "al maestro D.Adolfo A.Buylla",caps.XV, XVI y XVII.

${ }^{149}$ Véase, significativamente, la teorización desde la democracia liberal en favor de la democracia económica en DAHL,R.A.: Prefacio a la democracia económica (1985), Buenos Aires, Grupo Editor Latinoamericano, 1990.

${ }^{150}$ Posada elaboró un informe respecto a la representación de los trabajadores en los consejos de trabajo de distintos países. El texto de dicho informe fue publicado por el propio IRS, con el título La representación Obrera en los Consejos del Trabajo de Diferentes Países, Madrid, Suc.de M.Minuesa de los Ríos, Madrid, 1909.

${ }^{151}$ Posada era absolutamente consciente del declive del Estado liberal, y en particular de la decadencia del Estado de la Restauración desde su implantación hasta la descomposición del sistema con la Dictadura de Primo de Rivera. No tenía duda de la necesidad de una reforma en profundidad de las estructuras del Estado. De ahí que su arserto: "¿Qué es el Estado? El Estado es lo que todos sufrimos". Cfr.POSADA,A.: La nouvelle constitution espagnole. Le règime constitucionnel en Espagne, París, Sirey, 1932, pág.171. Esa defensa de una representación específica, especialmente del factor o elemento social, también POSADA,A.: El régimen constitucional. Esencia y forma. Principios y técnica, Madrid, Librería General de Victoriano Suárez, 1930, págs.60 y sigs.; POSADA,A.: Hacia un nuevo Derecho Político. Reflexiones y comentarios, Madrid, Paez=Bolsa/Sucesores de Rivadeneyra, 1931, págs. 7 y sigs.

${ }^{152}$ Se había hablado desde la lógica del discurso político interno al sitema establecido en crisis de "la cintura de defensa en torno al caos bolchevique". Cfr. AUNÓS PÉREZ,E.: Estudios de Derecho corporativo, Madrid, Reus, 1930, pág.16.

${ }^{153}$ No cabe duda que la propuesta del parlamento industrial estaba mediatizada por los acontecimientos contemporáneos, caracterizados por la celebración de una conferencia o parlamento industrial por el gobierno de coalición de Lloyd George con la finalidad de atenuar y controlar la conflictividad existente en Gran Bretaña. Noticia de ello da la revista España, 13 de marzo de 1919. Véase la edición facsimilar de la revista España, Est. introductorio de M.Tuñón de Lara, Madrid, Topos Verlag, Vaduz, Turner, 1982. El informe oportunísimo del IRS de ese año se publicó con el título, El problema obrero en Gran Bretaña. La Conferencia Industrial y los Informes del Comité Whitley, Madrid, Instituto de Reformas Sociales, Sobrinos de la Sucesora de M.Minuesa de los Ríos, 1919. 
institucional del Estado ${ }^{154}$. Posada era un reformista posibilista, que creía en la viabilidad de la transformación interior del sistema establecido, regenerando moralmente al individuo y reorientando a las instituciones en un sentido solidarista; y con ello superar la las luchas por el poder y la "voluntad de poder" entre las clases sociales. Pero el reformismo había realizado un diagnóstico equivocado de la realidad política de su tiempo ${ }^{155}$, y, además, era un partido desligado de las masas populares, lo cual no facilitaba la movilización necesaria para impulsar y llevar a cabo las reformas pretendidas. La reforma político-constitucional necesaria en el sentido de la realización del programa del liberalismo progresista fracasaría siendo aquélla una condición esencial para llevar a cabo la "revolución social" a través de una vía pacífica.

El intento consistía, pues, en la racionalización jurídica e institucional ("institucionalización") del problema social y en particular de la llamada cuestión social obrera. Lo que para el Partido Reformista y para el propio Posada se produciría más correctamente a través de un modelo corporativo democrático. Combinación entre miedo y convicción política y ética de la necesidad de abordar cambios profundos en el sistema político y jurídico (en la línea de creación de un estatuto jurídico del trabajo que sirviese para asentar un nuevo modelo de racionalización jurídica de la cuestión social). La política de reforma social podría evitar la revolución, a través de la intervención pública y el desarrollo una legislación protectora del trabajo asalariado ${ }^{156}$. Era un coyuntura política caracteriza por el cuestionamiento del orden establecido por el movimiento obrero organizado política y sindicalmente ${ }^{157}$, y donde abundaba de modo muy generalizado exigencias de control obrero sobre la economía y las industrias (los sindicatos presentaron en 1921 en el IRS una propuesta de control sindical en la industrias de interés nacional, siguiendo la estela de las experiencias del Reino Unido y de Alemania). Una coyuntura caracterizada por la resistencia a las reformas más intensas por la clase empresarial y la tentación hacia la "salida autoritaria" que finalmente cobró realidad con el golpe de Estado de Primo de Rivera. Existiendo una

\footnotetext{
${ }^{154}$ En los debates parlamentarios había observado Melquíades Álvarez que "Lo que tiene que hace el poder público es evitar, como aquí se dijo esta tarde, que esos Sindicatos actúen en la sombra y en la clandestinidad, trayéndolos, por el contrario, a la vida legal: y con la Ley de Asociaciones, Sr.Cambó, o con otras leyes si fuera preciso. Hacer que el poder público, como el Argos de la fábula, sea vigilante y penetre en todas las decisiones del Sindicato, sin que haya nada que se escape a la mirada oficial, ni cotizaciones, ni acuerdos, ni acto alguno que se quiera realizar. Entonces, por la habilidad del gobernante atraeréis al Sindicato a la esfera legal, convirtiéndolo, de fuera revolucionaria, en fuerza de colaboración eficaz para una obra progresiva". Cfr. Diario de Sesiones de las Cortes, 11 de febrero de 1921. Intervención de Melquiades Álvarez en el debate parlamentario relativo a la gestión del gobernador civil de Barcelona en relación al terrorismo.

${ }^{155}$ Véase SUÁREZ CORTINA: "Melquiades Álvarez et le républicanisme démocratique sous la Restauration (1900-1923)", en Azaña et son temps, Madrid, Collection de la Casa de Velázquez, 1993; SUÁREZ CORTINA: El reformismo en España. Republicanos reformistas bajo la Monarquía de Alfonso XIII, Madrid, Siglo XXI, 1986.

${ }^{156}$ Véase SALES Y FERRÉ,M.: "Evolución social contemporánea" en La España Moderna, 1908, págs.5 y sigs.

${ }^{157}$ Véase JUTGLAR,A.: La era industrial en España. Aproximación a la historia social de la España contemporánea, Barcelona, Nova Terra, 1963; TUÑON DE LARA,M.: El movimiento obrero en la Historia de España, Madrid, Taurus, 1972; FUSI,J.P.: Política obrera en el País Vasco, 1880-1923, Madrid, Turner, 1975; PÉREZ LEDESMA,M.: "La formación de la clase obrera. Una creación cultural", en CRUZ,R.y PÉREZ LEDESMA,M.(eds.): Cultura y movilización en la España contemporánea, Madrid, Alianza Editorial, 1997, págs.201 a 233.
} 
presión generalizada desde el movimiento obrero y de los grupos reformistas por una rectificación del orden individualista que por entonces imperaba. Uno de los problemas para instaurar ese corporativismo democrático era las limitaciones en el reconocimiento de las organizaciones sindicales representativas que estaban en plena lucha reivindicativa por el pleno reconocimiento de la legitimidad y legalidad de su misma representatividad sindical. De ahí las constantes huelgas, incluidas la convocatoria de huelgas generales en el período de entreguerras ${ }^{158}$. Cualquier política de democratización del sistema debería pasar por ese reconocimiento de las organizaciones sindicales representativas consagrando un régimen de pluralidad sindical no excluyente.

La proximidad de puntos de vista más allá de la afiliación político-ideología es notoria. Así Fernando de los Ríos la propuesta de un "parlamento industrial" era un elemento de una construcción corporativa y orgánica de la sociedad que debe ampliarse hasta alcanzar su órgano supremo en el Consejo Económico instituido por la Constitución alemana (art.165), que sería un esbozo de lo que podría ser en un mañana próximo el "Parlamento Industrial", donde esté representado el "hombre profesional"159. Estas reflexiones pueden superponerse, e incluso solaparse, con las realizadas por Posada en obras como El régimen constitucional y La reforma constitucional. Posada coincidiría con la posición crítica adoptada en un momento histórico crítico por Fernando de los Ríos cuando esté rechazaría un nuevo tipo de "Estado corporativo", entendido como una unidad superior con voluntad única, a fin de realizar los fines nacionales, siéndole preciso para ello superar la existencia de partidos y utilizar los sindicatos como órganos indirectos de acción estatal ${ }^{160}$. En Posada, como en Fernando de los Ríos y Julián Besteiro, la representación de los intereses se enmarca en una propuesta de reforma constitucional que no se constituía en alternativa al parlamento liberal, sino como vía para que la sociedad pluralista realmente existente penetrase en la "constitución oficial" del régimen pseudoliberal en crisis ${ }^{161}$. Trataba de afrontar mediante

\footnotetext{
${ }^{158}$ Véase MARTÍN, B.: Los problemas de la modernización. Movimiento obrero e industrialización en España, Madrid, MTSS, 1992, págs. 360 y sigs.

${ }^{159}$ RÍOS,F.DE LOS.: El sentido humanista del socialismo, cit., pág.377. No estaba sólo Fernando de los Ríos, ni en España, ni en el extranjero. En este sentido es importante reparar en la propuesta de Lloyd George de llevar a cabo un vía corporativa como remedio para atenuar los conflictos existente entre el capital y el trabajo, pero respetando el marco de la democracia parlamentaria. Cfr. MIDDLEMAS,K.: Politics in Industrial Society. The Experience of the British System since 1911, A.D., 1979.

${ }^{160}$ RÍOS,F.DE LOS.: "¿Hacia un Estado corporativo?", en Leviatán, núm. 2 (junio de 1934), pág.10. En realidad el modo de pensar criticado era el reflejado en la propuesta también concurrente de los grupos políticos conservadoras, como la C.E.D.A. de Gil-Robles, de constituir una segunda cámara corporativa (un "Senado corporativo"), traduciendo la visión ideológica del corporativismo defendido por el catolicismo social conservador. La propuesta conservadora de un "Senado corporativo" puede localizarse en GIL-ROBLES: Discursos parlamentarios, Madrid, Taurus, 1971, pág.23. Puede consultarse MONTERO,J.R.: La CEDA. El catolicismo social y político en la II República, vol.I, Madrid, Eds.de la Revista de Trabajo, 1977, passim.

${ }^{161}$ Véase POSADA,A.: "Reflexiones sobre la crisis del liberalismo", en POSADA,A.: Actitud ética ante la guerra y la paz, Madrid, Caro Raggio Editor, 1923, págs.186-187. Por otra parte, recuerda que Giner hablaba de "un Estado "oficial" y de un Estado "no oficial". La virtualidad máxima del Estado entrañaba para él la compenetración social y ética de ambos Estados. Por otra parte, el Estado, el pleno Estado ideal, requiere la comprensión, en amplio orden de justicia, de las personas individuales y sociales que en realidad lo constituyen" (Ibid., pág.192). Práxedes Zancada haciéndose eco de la denuncia costiana de la constitución real como constitución de la oligarquía frente a la constitución oficial de la Restauración, señalaba, con contundencia, que el gran problema es "que el régimen parlamentario, leal y sinceramente, no ha existido en España, y que las
} 
innovaciones constitucionales la crisis palpable de un régimen parlamentario que en España no se podía considerar plenamente democrático (el régimen de la Restauración era una pseudodemocracia parlamentaria ${ }^{162}$ ) y el fracaso de ese sistema, precisamente por su falta de autenticidad y su compromiso con las clases más acomodadas, en dar una respuesta adecuada e integradora al "problema social". Él apuesta por un republicanismo o liberalismo social, opuesto al liberalismo abstracto ${ }^{163}$ y formal y al economicismo del "laisser faire", y que podría definirse como una filosofía de la libertad, pero de la libertad con contenido ético y de enjundia social. Esa concepción de la libertad obliga a transformar el Estado en un orden jurídico, de acción positiva, que no puede -no debe- permanecer indiferente ante las injusticias sociales. Se trataba de armonizar las exigencias de un régimen liberal -de derechos del hombre, de garantías jurídicas de las libertades- con las de la justicia social que demanda una calculada y eficaz intervención del Estado -que es, para él la sociedad misma jurídicamente organizada al efecto de defender y tutelar al débil en las luchas de la vida y de difundir por la sociedad entera para todos los goces de aquélla, de la vida, haciendo de la igualdad abstracta de la Declaración de derechos de 1789 (art.1 ${ }^{\circ}$ ) la igualdad orgánica espontáneamente jerarquizada por obra de la necesaria diferenciación de las funciones sociales $^{164}$.

Adolfo Posada se había manifestado reiteradamente, y de modo contundente, en contra de ese régimen pseudodemocrático ${ }^{165}$ y después contra la Dictadura de Primo de Rivera ${ }^{166}$;

Cortes no han representado la voluntad de la Nación, sino la voluntad de los oligarcas". Cfr. ZANCADA,P.: Los problemas constitucionales de España, cit., pág.43.

${ }^{162}$ Véase la formulación clásica de COSTA,J.: Oligarquía y caciquismo como la forma actual de gobierno en España: urgencia y modo de cambiarla, vol.I, Zaragoza, Guara editorial, 1982; VARELA ORTEGA,J.: Los amigos políticos. Partidos, elecciones y caciquismo en la Restauración (1875-1900), Madrid, Alianza, 1977. El propio POSADA,A.: La reforma constitucional, Madrid, Librería de Victoriano Suárez, 1931, págs.153 y sigs. Posada resumía los defectos capitales del régimen constitucional español, en los siguientes términos: " 1 \%., insinceridad y corrupción en la base electoral; $2^{\circ}$, descomposición parlamentaria sin partidos políticos, sustituidos por grupos y clientes; $3^{\circ}$., predominio arbitrario del Ejecutivo, con las Cortes a merced de los Gobiernos; $4^{\circ}$, inclinaciones al poder personal en la Corona, sostenidas, o mejor, excitadas por la continuada ausencia de las Cortes y la adaptación benévola de tantos hombres políticos (Ibid., págs.155-156).

${ }^{163}$ Giner hablaba de una reacción contra el liberalismo abstracto en GINER DE LOS RÍOS,F.: Persona social. Estudios y fragmentos, Madrid, Librería General de Victoriano Suárez, 1899, pág.239, nota 1 (Reedición crítica con estudio preliminar a cargo de J.L. Monereo Pérez, Granada, Comares (Colección Crítica del Derecho), 2008).

164"Prólogo", escrito en Salinas-Avilés (Asturias), 1ª de agosto de 1931, al libro de AZCÁRATE,G.D.: El régimen parlamentario en la práctica ( $1^{\mathrm{a}}$ ed., $1885 ; 2^{\mathrm{a}}$ ed., 1931), Prólogos de Adolfo Posada y E.Tierno Galván, Madrid, Tecnos, 1978, pág.4.

${ }^{165} \mathrm{Y}$ lo hizo tempranamente, POSADA,A.: El parlamentarismo, conferencias pronunciadas en el Casino de Oviedo en febrero de 1887), Oviedo, Publicaciones de la Revista de Asturias, 1887. Son expresivas de su posición las reflexiones que se recoge en sus Fragmentos de mis Memorias.

${ }^{166}$ Con referencia, y complicidad con el ideario de Azcárate, así lo señaló Posada en su "Prólogo", escrito en Salinas-Avilés (Asturias), $1^{\text {a }}$ de agosto de 1931, al libro de AZCÁRATE,G.D.: El régimen parlamentario en la práctica ( $1^{a}$ ed., 1885; $2^{a}$ ed., 1931), Prólogos de Adolfo Posada y E.Tierno Galván, Madrid, Tecnos, 1978, pág.1, indicando que Azcárate se había caracterizado por la defensa "de la acción eficaz del Parlamento, reducido éste a su papel y curado de las corruptelas que han provocado su descrédito. Azcárate, en síntesis, fue, en vida, apóstol de los ideales político de los pueblos libres, y de la intimidad salvadora entre la ética y la política, mediante el derecho, es decir, cuanto vino a negar, desconocer o atropellar la Dictadura, que, en cambio, entronizaba el régimen de fuerza, con la consiguiente destrucción de todo régimen de ley. Azcárate y Dictadura son términos, en verdad, que se excluyen o, mejor, se repelen, como se repelen ley y arbitrariedad, 
como también la afirmación de la manifiesta incompatibilidad de la Monarquía doctrinaria con el principio del Self-government o de soberanía nacional ${ }^{167}$. Dirá, con Azcárate en 1931 que el régimen parlamentario, última evolución del sistema representativo y consecuencia del principio del Self-government o de la soberanía nacional, es la única solución justa y conveniente, y la única posible, del problema político de nuestros días ${ }^{168}$. En la transición de la Dictadura a la democracia de la II República había propuesto esa fórmula bicameral, recordando su coherencia con el organicismo espiritualista que inspiraba al krausismo ${ }^{169}$. De acuerdo con su teoría organicista de la representación, Posada trata de convertir al Senado, de una Cámara de nobles y altas categorías oficiales en un cuerpo de base sindical y política en el que todos los elementos sociales organizados pudiesen hacerse escuchar y colaborar en la obra de la Ley y en la tarea de regir la vida económica del país y contribuir juntos a marcar el rumbo político de la nación ${ }^{170}$. Él trataba de condensar la compleja voluntad colectiva del Pueblo en una sociedad fragmentada, y creía encontrar el medio idóneo en una estructura institucional en la que estuviesen representados todos los intereses de grupo, locales, económicos o de carácter social. Se creía que la representación de intereses contribuiría a representar no sólo al "hombre individual" sino también al "hombre colectivo" perteneciente a diversas formaciones sociales, lo cual sería una vía para superar el individualismo liberal y garantizar la democratización del Estado mediante su socialización corporativo-institucional y orientación hacia la justicia ${ }^{171}$. Ello daría nuevo sentido a la construcción de un verdadero Estado representativo u orgánicamente constituido mediante

\footnotetext{
civitas y estado de naturaleza".

167"Prólogo", escrito en Salinas-Avilés (Asturias), $1^{\text {a }}$ de agosto de 1931, al libro de AZCÁRATE,G.D.: El régimen parlamentario en la práctica ( $1^{\text {aa }}$ ed., 1885; $2^{\text {a }}$ ed., 1931), Prólogos de Adolfo Posada y E.Tierno Galván, Madrid, Tecnos, 1978, pág.3. Nuevamente vierte una afirmación que podría proyectarse sobre él mismo: "fue, sin duda, una de las labores de Azcárate -en la madurez de su vida y cuando alcanzara su máxima autoridad como parlamentario -rectificar, o destruir, o desvanecer los prejuicios y supervivencias del doctrinarismo monárquico en que descansaba la fórmula constitucional española de 1876, a fin de transformar, sin violencias, el régimen doctrinario y de desconfianzas de la Restauración, en un régimen representativo, democrático y "sin obstáculos tradicionales"".

168"Prólogo", escrito en Salinas-Avilés (Asturias), $1^{\text {a }}$ de agosto de 1931, al libro de AZCÁRATE,G.D.: El régimen parlamentario en la práctica ( $1^{\mathrm{a}}$ ed., 1885; $2^{\mathrm{a}}$ ed., 1931), Prólogos de Adolfo Posada y E.Tierno Galván, Madrid, Tecnos, 1978, pág.8. Son palabras, asumidas por él, Azcárate (Ibid., "Prólogo" de Azcárate, pág.11).

${ }^{169}$ Así recordará la influencia que Giner tuvo en la vertiente corporativa del Senado en la Constitución de 1876, y propondría una cámara profesional para la nueva constitución de la II República. Véase, respectivamente, POSADA,A.: El régimen constitucional, Madrid, Librería General de Victoriano Suárez, 1930, pág.169.; y Tratado de Derecho Político, Madrid, Librería General de Victoriano Suárez, 1935, págs.249 y sigs. (Reedición en un solo volumen y estudio preliminar a cargo de J.L. Monereo Pérez, Granada, Comares (Col. Crítica del Derecho), 2003.

${ }^{170}$ En este sentido POSADA,A.: España en crisis, la política, Madrid, Caro Reggio, 1923, págs.166.

${ }^{171}$ Dice Posada que la democracia es, pues, avance político mesurado hacia un régimen de justicia... mejor, de liberación, de elevación expansiva del tipo de vida. Pero, a mi ver, la democracia significa previamente, y a la vez que avance, el desplazamiento de alguna cosa esencial en y para el régimen del Estado... Supone, en efecto, la democracia un movimiento del Estado hacia "adentro", hacia sí, y merced al cual se pone la fuente del poder propio del Estado, capaz de establecer y mantener un orden jurídico, o sea, la realidad de un ideal de justicia, en la comunidad política, y, así, donde antes se decía rey, clase dominante, grupo de gobernantes.., debe decirse pueblo, nación, "ciudad", en el profundo sentido de la antigüedad clásica remozada por la revolución moderna. Cfr. POSADA,A.: "Reflexiones sobre la crisis del liberalismo", en POSADA,A.: Actitud ética ante la guerra y la paz, Madrid, Caro Raggio Editor, 1923, pág.198.
} 
un sistema bicameral ${ }^{172}$. En este sentido la propuesta de Posada era contraria a la pretensión de crear un parlamento industrial o corporativo, defendiendo la creación de dos cámaras parlamentarias. La propuesta no cabe duda que estaba influida por la creación de un organismo diferente, pero que tenía en común el tener en cuenta la representación de intereses respetando, sin embargo, al parlamento elegido por sufragio universal: se trataba de la previsión de un "Consejo Económico del Reich" en la Constitución de Weimar de 1919, art.165, con funciones complementarias y no sustitutivas de aquél; a saber: funciones de consulta y de iniciativa legislativa respecto a proyectos de ley en materia económica y social $^{173}$.

La propuesta de Posada (que no se enmarcaba en una ofensiva antiliberal y antipartidista, como era tan frecuente desde el lado conservador) entroncaba con ciertas experiencias europeas y conectaba con una sentida aspiración del movimiento sindical a intervenir directamente en la vida política. La idea corporativa estaba muy arraigada en los sindicatos europeos y en el pensamiento constitucionalista (un exponente harto significativo era León Duguit); como la misma idea de "corrección orgánica" en la estructura representativa de la democracia liberal ${ }^{174}$. Estaba desde luego muy presente en el ambiente político e intelectual de la época. En este sentido conviene tener en cuenta que el debate sobre la necesidad de crear un "Parlamento Industrial" -que ya estaba presente dentro de las filas del krausismofue lanzado a la arena política por la Revista España, en gran medida como reflejo interno de las propuestas en este sentido formuladas por Lloyd George ${ }^{175}$. Pero encontraba también sus fundamentos doctrinales en el socialismo fabiano, al que por entonces estaba muy próximo H.J.Laski, que defendía al mismo tiempo la autonomía de los grupos profesionales y su participación institucional en el sistema político ${ }^{176}$.

\footnotetext{
${ }^{172}$ Cfr. POSADA,A.: El régimen constitucional, cit., pág.60; POSADA,A.: La crisis del Estado y el Derecho político, Madrid, C.Bermejo, 1934. Según Posada "la organización constitucional más aceptable en las democracias modernas será, sin duda, aquella mediante la cual se logre hacer efectiva la armonía de todos los intereses, de modo que predomina la preocupación del interés nacional o general. La democracia no puede ignorar la existencia de los intereses diferenciados en el seno de la vida nacional". Cfr. POSADA,A.: La reforma constitucional, cit.,pág.142.

${ }^{173}$ Véase KORSCH,K.: Lucha de clases y Derecho del Trabajo (1922), trad.de J.L.Vernal, Barcelona, Ariel, 1980; NEUMANN,F.: Behemoth. Pensamiento y acción en el nacional-socialismo (1942), México, FCE, 1983. Véase VV.AA.: La Constitución de Weimar (Texto de la Constitución alemana de 11 de agosto de 1919), Madrid, Tecnos, 2019, con los estudios pioneros de Ottmar Bühler, Walter Jellinek y Costantino Mortati, y la presentación de la edición de Juan Antonio García Amado.

${ }^{174}$ El clima intelectual está bien reflejado en las obras del período. Puede consultarse, al respecto, GARCÍA CANALES,M.: La teoría de la representación en la España del siglo XX, Murcia (Universidad), 1977, passim.

${ }^{175}$ Véase España, 205, 13-II.1919. "La marejada sindicalista", y números posteriores hasta el 212, 1-V-1919. De ello se hace eco BARRIO ALONSO,A.: El sueño de la democracia industrial. Sindicalismo y política en España, 1917-1923, Santander, Universidad de Cantabria, 1997, págs.63 y sigs.; BARRIO ALONSO,A.: "Un parlamento industrial en España", en Melanges de la Casa de Velázquez (MCV), 1995, XXXI (3), págs.35 a 57. También LAMO DE ESPINOSA,E.y CONTRERAS,M.: Política y filosofía en Julián Besteiro, Madrid, Sistema, 1990; MONEREO PÉREZ,J.L.: "El pensamiento jurídico-social de Fernando de los Ríos", en AA.VV.: Congreso sobre Fernando de los Ríos y su tiempo, Gregorio Cámara (Coord.)., Granada, Servicio de Publicaciones de la Universidad de Granada, 1999.

${ }^{176}$ Es harto significativo que una persona tan vinculada al Partido Reformista al inicio de la década de los veinte (véase su artículo "La vieja política. Catalanismo y plutocracia", en El Noroeste, Gijón, 20-II-1921), fuese el traductor de la obra principal de Laski, nítidamente vinculada al socialismo fabiano y al filosofía del
} 
Esta concepción organicista la propuso formalmente en las "Bases para la Constitución política de España", como una vía de transición de la Dictadura de Primo de Rivera hacia una régimen democrático, y en el Anteproyecto de la Comisión Jurídica Asesora, dentro del período repúblico ${ }^{177}$ (Anteproyecto de Constitución de la República española, que eleva al Gobierno la Comisión Jurídica Asesora, Madrid, julio de 1931). La Comisión Jurídica Asesora del Gobierno había sido impulsada directamente por Fernando de los Ríos ${ }^{178}$. El mismo Fernando de los Ríos había promovido a Adolfo Posada a presidente del Consejo Superior de Trabajo, el cual tomó posesión de su cargo. Posada sería el primer presidente del Consejo de Trabajo de la República. Fue nombrado también presidente del Instituto Nacional de Previsión, cargo del que fue destituido por el Gobierno del Frente Popular. Adolfo Posada seguía vinculado con el reformismo de Melquíades Álvarez (entonces como partido republicano liberal-demócrata), como se expresaba significativamente en la reunión de 24 de mayo de 1931 en los salones del Hotel Palace de Madrid, donde la presidencia estaba integrada por Álvarez Valdés, Posada, Villalobos, Zulueta, Pedregal y Hoyos Sáinz. Adolfo Posada se separaría del Partido liberal demócrata (tras los sucesos de Asturias de 1931 el partido había acordado renunciar a toda clase de cargos públicos ${ }^{179}$ ) meses después permaneciendo como presidente del Consejo Superior de Trabajo.

Este proyecto fue rechazado por las Cortes Constituyentes de 1931, por entender que no deberían superponerse los intereses corporativos o profesionales a los intereses generales representados a través de los partidos políticos. De mismo modo habían sido rechazados proyectos de contenido en parte similar de Julián Besteiro -que proponía una segunda

pluralismo político y social. Cfr. LASKI,H.J.: El Estado Moderno. Sus Instituciones políticas y Económicas, trad., Prólogo y Notas, por Teodoro González García (catedrático de Derecho Político, Universidad de Oviedo -también-), Barcelona, Librería Bosch, 1932. Reeditada en Granada, Comares (Colección Crítica del Derecho), Est.prel., de J.L.Monereo Pérez, 2003. González García defiende la autonomía de los grupos -que no dependen en su origen de la voluntad del Estado-, y muestra su simpatía hacia el pluralismo político y social (véase "Prólogo del traductor"). Para él "si el grupo constituye, simplemente, un fenómeno de adición a las fuerzas individuales contribuirán a perfeccionar, al mismo tiempo, los fines del Estado y la propia actividad individual. En este sentido, muy bien puede el Estado transferir a los grupos aquellas atribuciones que no revelen un sentido de impotencia e ineficacia, sino una definición más perfecta de los deberes implícitos en su aptitud" ("Prólogo del traductor", pág.XXVIII).

${ }^{177}$ Posada tuvo una importante contribución en la redacción del Anteproyecto de Constitución, en virtud de su pertenencia a la Subcomisión técnica creada por Decreto de 6 de mayo de 1931, por iniciativa de Fernando de los Ríos, en su calidad de Ministro de Justicia. Esta Subcomisión estuvo formada por Angel Ossorio y Gallardo (Presidente), Adolfo Posada, Javier Elola, Valeriano Casanueva, Manuel Pedroso, Nicolás Alcalá Espinosa, Agustín Viñuales, Antonio Rodríguez Pérez, Alfono García Valdecasas, Francisco Romero Otazo, Luis Lamana Lizarbe, José Castán, Luis Jiménez de Asúa, José Antón Oneca, Antonio de Luna y Juan Lladó Sánchez Blanco. Sobre la elaboración de la Constitución Republicana de 1931, véase PÉREZ SERRANO,N.: La Constitución española (9 de Diciembre). Antecedentes. Textos. Comentarios (1932), Madrid, Rev. de Derecho Privado, 1932. Para los antecedentes, la propia obra de POSADA,A.: La nouvelle Constitution espagnole, París, Prefacio de Barthelemuy, 1932, passim. Sobre el debate en torno al sistema unicameral o bicameral, véase GARCÍA CANALES,M.: La teoría de la representación en la España del siglo XX, Murcia, Publicaciones del Departamento de Derecho Político-Secretariado de Publicaciones, Universidad de Murcia, 1977, págs.238 y sigs.

${ }^{178}$ De ello da cumplida noticia, ZAPATERO,V.: Fernando de los Ríos. Biografía intelectual, Valencia, Pretextos-Diputación de Granada, 1999, págs.279-280.

${ }^{179}$ GARCÍA VENERO,M.: Melquiades Álvarez. Historia de un liberal, Prólogo de Azorín, $2^{\mathrm{a}}$ ed., ampliada, Madrid, Eds.Tebas,1974, pág.441. 
cámara profesional- y Fernando de los Ríos -que insistía muy matizadamente en ese organicismo corporativista pero añadía también su preocupación por la tecnificación del trabajo parlamentario ${ }^{180}$, que él creía poder afrontar a través de los "Consejos técnicos"181. Una figura que estaba proponiéndose en otros países y que había preocupado a autores, como él, inscritos en el socialismo democrático pluralista, acompañado de un rechazo sin fisuras de todo régimen totalitario. Es el caso del primer H.J.Laski ${ }^{182}$, con el que el pensamiento organicista de Posada podía encontrar cierta afinidad; y es que la propuesta de Posada (como la de Besteiro y Fernando de los Ríos) de una cámara profesional sintonizaba con las orientaciones organicistas y corporativistas pero era especialmente próxima al socialismo gremial, aunque pronto sería abandonada ${ }^{183}$. En este caso el corporativismo democrático subyacente a esas propuestas trataba de reconducir hacia el espacio político institucional los conflictos socio-económicos, promoviendo el creciente protagonismo de las organizaciones de intereses en la toma de decisiones políticas, lo que entrañaba una nueva distribución de poderes en el sistema democrático ${ }^{184}$.

\footnotetext{
${ }^{180}$ La preocupación por la tecnificación ante la complejidad de las funciones de un Estado de servicio público es manifiesta en POSADA,A.: La reforma constitucional, cit., págs. 150 y sigs., partiendo de la idea de que es la misma democracia la que reclama un régimen de eficacia. Uno de los máximos exponentes de la evolución hacia el Estado de servicio público, puso de manifiesto que hoy día el servicio público es la piedra angular del Derecho administrativo, especialmente atendiendo a la derivación del Estado liberal hacia la forma del Estado social.Véase JÈZE,G.: Los principios generales del Derecho Administrativo, cit., págs.283 y sigs.

${ }^{181}$ También, siguiendo la estela de Fernando de los Ríos, ROIG IBAÑEZ, La Constitución que necesita España, Madrid, E.Javier Morata, 1930, pág.124, que las concibe como medio de simplificación de la actividad parlamentaria e, incluso, como cauce de participación de los ciudadanos especialmente interesados, o conocedores de la materia a legislar.

${ }^{182}$ Veáse MONEREO PÉREZ,J.L.: "La filosofía política de Harold J. Laski”, Est.prel., a la obra de LASKI,H.J.: La Gramática de la Política, Granada, Comares (Colección Crítica del Derecho), 2003, págs. XVC.; MONEREO PÉREZ, J.L.: La democracia en crisis: Harold J. Laski, Barcelona, Ediciones de Intervención Cultural/El Viejo Topo, 2004.

${ }^{183}$ El "socialismo de cátedra" en la figura de Schäffle había señalado que a la representación nacional falta la expresión del elemento corporativo, municipal y profesional. Las bases de la representación nacional son para él deficientes. La nación es, sin duda, para los efectos de la participación en el poder, la suma de todos sus varones mayores de veinticinco años (que son las condiciones que al elector impone Schäffle); pero también es algo más: la nación es un organismo de corporaciones "públicas", ya municipales, ya profesionales, que deben tener igualmente su representación al lado de "la masa elemental", a que el sufragio universal corresponde. De aquí, el sistema que propone Schäffle: una doble representación, sea en dos Cámaras, sea en una sola (que es lo que le parece más sencillo); sistema que es calcado de Ahrens, a distinción del de Röder, que no quiere admitir la representación de la masa de individuos, y pide que las dos Cámaras sean igualmente corporativas, constando, una, de delegados municipales, y otra, de delegados de las profesiones. Cfr. GINER DE LOS RÍOS,F.: Persona social. Estudios y fragmentos, Madrid, Librería General de Victoriano Suárez, 1899, págs.321-322.

${ }^{184}$ En no poco existe cierta similitud, sólo en el campo de las "preocupaciones", de otorgar relevancia política a las organizaciones, con el corporativismo democrático que se puso en práctica en el último tercio del siglo veinte, tanto en el plano institucional (participación institucional) como en el de la acción política (acuerdos o pactos de concertación social). Para estos fenómenos, puede consultarse BERGER,S.(ed.): La organización de los grupos de interés en Europa occidental, Madrid, MTSS, 1988; MONEREO PÉREZ,J.L.: Concertación y diálogo social, Valladolid, Lex Nova, 1999, destacando su relevancia política para la gobernabilidad del sistema y su trascendencia en las políticas de racionalización productiva, y distributiva, llevadas a cabo en el último tercio del siglo veinte; al mismo tiempo que la importancia de la concertación y del diálogo social en la construcción del espacio social europeo.
} 
Adolfo Posada pensaba que la presencia de las organizaciones de intereses en las estructuras del Estado, atribuyéndole, pues, una función sociopolítica llevaría a introducir una lógica más de colaboración que de confrontación. Su experiencia (señaladamente su labor en el IRS) le había demostrado la utilidad para de crear cauces institucionalizados para el encuentro y el diálogo entre los actores sociales. Su proyecto de transformación se vinculaba a los "socialistas de cátedra" (en realidad, por su doctrina más liberal-sociales que propiamente socialistas) que, como Schäffle había defendido la oportunidad de organización una representación política de la clase obrera en el Estado democrático, precisamente en el marco de un amplio programa de política social. Una de las condiciones insertas en ese programa de política social de Schäffle es la representación de los trabajadores. Como señalaba Giner, en la exposición de la doctrina de dicho autor, ya el partido democrático social había pedido en Alemania, en 1885 y en 1890, la constitución de una Cámara (Parlamento del Trabajo) donde hallase representación especial la clase obrera de todo el Imperio. Sólo hay que notar que las cámaras, consejos, jurados y demás se compondrían por partes iguales de empresarios y de obreros, sobre la base del sufragio universal. Consideraba Schäffle esta propuesta como el medio más hábil posible de preparar de un modo legal el advenimiento del colectivismo, de tal suerte, que en su día bastase suprimir de pronto la participación dada ahora a los empresarios, para encontrarse constituida, con hábitos y experiencias del Gobierno, la supremacía de los trabajadores y el "Estado popular" ${ }^{185}$. Con este tipo de medidas, entendía Schäffle, que el socialismo no se limitaba a reclamar la intervención del Estado liberal contra la "tiranía capitalista" y en favor de las clases obreras, sino que caminaría en la dirección de una transformación cualitativa en su organización interna.

Todos ellos querían afrontar el problema de la complejidad de una sociedad fragmentada y dividida con la pretensión de que las dos cámaras permitiría deslindar el ámbito del interés general compartido en el proyecto de sociedad inserto en la idea de ciudadano

\footnotetext{
${ }^{185}$ GINER DE LOS RÍOS,F.: Persona social. Estudios y fragmentos, Madrid, Librería General de Victoriano Suárez, 1899 (Reedición crítica con estudio preliminar a cargo de J.L. Monereo Pérez, Granada, Comares (Col. Crítica del Derecho), 2008), pág.349. Giner aprecia una evolución del último Schäffle hacia el "colectivismo" cuya defensa iría más allá de los postulados afirmados por "los socialistas de cátedra" (donde incluye también a Schmoller, Wagner, Th Ziegler (Catedrático de Filosofía de la Universidad de Estrasburgo), y "quizá -dicenuestros Azcárate y Buylla"). Sin embargo, señala que Schäffle continua manifestándose contrario a la revolución y decididamente partidario de la "política social", la cual sin subvertir las bases actuales de la organización económica, atenúe sus inconvenientes, sus vicios y sus ásperas luchas inhumanas, ennobleciendo a un tiempo al trabajador y al capitalista, y confiando en parte esta intervención tutelar y pacificadora al Estado (véase, Ibid.,pág.422). He aquí como se filtra la propia posición de Giner: es partidario de una política social de reforma, no de revolución, paliativa de la situación de los trabajadores y armonizadora entre los intereses del capital y del trabajo. Por su parte, el Estado ha de realizar una intervención de carácter tutelar y pacificador, una política de orden basada en la justicia social. La influencia de Schäffle es manifiesto en Morote (el "gran socialista de cátedra" según él), lo que puede comprobarse en MOROTE,L.: La moral de la derrota, Madrid, Impr.G.Juste, 1900, donde apuesta por una regeneración basada en la implantación de un régimen democrático con contenido social. Habla, al efecto, de la instauración de una "República de contenido social" (Ibid.,pág.589). Puede consultarse, ZIEGLER, TH.: La cuestión social es una cuestión moral, 2 tomos, versión española de la última edición alemana por Rafael Montestruc, Barcelona, Imprenta de Hennri y C a .-Editores, 1904. Véase, MONEREO PÉREZ, J.: El 'Socialismo de cátedra' de Gustav Schmoller en la construcción de la Politica social moderna, en Revista Europea de Historia de las Ideas Políticas y de las Instituciones Públicas, 2017, issue 11. https://econpapers.repec.org/article/ervrehipi/y_3a2017 3ai_3a11_3a03.htm.
} 
abstractamente considerado y en la política de partido y el ámbito de los intereses particulares económicos y sociales que se diferenciarían del interés general. Sin embargo, esa idea de una democracia orgánica era poco realista y entrañaba riesgos importantes para la el funcionamiento transparente del sistema democrático ${ }^{186}$; además, la coyuntura social se había venido agravando desde principios de la década de veinte ${ }^{187}$. Por otra parte, la noción de interés general es compleja y en términos generales más que una categoría abstracta y pretendidamente autónoma supone una búsqueda de síntesis de opuestos intereses particulares o parciales. Esta es, en el fondo, la consecuencia más coherente con un sistema de democracia pluralista. El sistema democrático, como la experiencia histórica contemporánea ha demostrado, puede articular otros cauces para la toma en consideración de los intereses económicos y sociales organizados, aunque ello haya planteado -y planteauna fuerte tensión con la autonomía legislativa del Parlamento y, por parte, con el principio de legitimidad democrática. Las fórmulas de la concertación social, el llamado neocorporativismo democrático, la negociación del Gobierno con los grupos económicos y financieros, son expresiones de una actividad de negociación política previa del contenido de las leyes ${ }^{188}$. Por otra parte, toda una teoría política, la teoría la democracia pluralista, trata de poner de relieve el pluralismo de los centros de poder en una sociedad como la del capitalismo tardío abierta y en transformación constante ${ }^{189}$. Se ha caminado también en la participación institucional de las organizaciones profesionales y económicas en la estructuras del Estado, pero sin incurrir en la atribución a las mismas de competencias legislativas. Es significativa la creación de organismos consultivos como el Consejo Económico y Social y los órganos específicos existentes en las Comunidades Autónomas.

\footnotetext{
${ }^{186} \mathrm{La}$ derecha y los empresarios, por lo demás, para mayor confusión, había aceptado con matices, pero aceptado al fin y al cabo la propuesta de un parlamento industrial (Congreso de Vigo de 1921). Véase ZANCADA,P.: Derecho Corporativo Español. Organización del Trabajo, Madrid, Juan Ortiz editor, s.f., págs.141 y sigs. Un ejemplo significativo de ello puede encontrarse en la defensa de un sistema de representación corporativa de carácter complementario a la política realizada por el Vizconde de Eza. Véase VIZCONDE DE EZA, EL.: La nueva democracia social, Madrid, Imprenta Bernardo Rodríguez, 1918.

${ }^{187}$ Sobre el ambiente de conflictividad general, véase MARTÍN,B.: Los problemas de la modernización. Movimiento obrero e industrialización en España, Madrid, MTSS, 1992, págs.360 y sigs.

${ }^{188}$ Para esas tensiones de competencias, véase BOBBIO,N.: El futuro de la democracia, Barcelona, PlanetaAgostini, 1994; MONEREO PÉREZ,J.L.: Concertación y diálogo social, Valladolid, Lex Nova, 1999. Rubio Llorente muestra una cierta preocupación, al respecto: "En Europa aceptamos con absoluta normalidad que el Gobierno negocie con los Sindicatos o con las Asociaciones patronales los presupuestos o las reformas legales antes de llevarlos al Parlamento y damos por supuesto que, de manera más directa, también el Gobierno negocia con grandes grupos financieros medidas que a todos nos afectan, pero es evidente que tal aceptación tiene como supuesto implícito una resignada visión del Parlamento que se aviene mal con el lugar que al mismo asigna la teoría normativa de la democracia parlamentaria". Cfr. RUBIO LLORENTE,F.: "Estudio preliminar" a la obra de POSADA,A.: Estudios sobre el Régimen Parlamentario en España, Oviedo, Junta General del Principado de Asturias, 1996, pág. LXXXII.

${ }^{189}$ Es clásica la aportación de DAHL,R.: La poliarquía, Madrid, tecnos,1997.
} 
El Proyecto que tuvo aceptación ${ }^{190}$ el que se elaboraría después por la "Comisión Parlamentaria de Constitución", presidida por Luis Jiménez de Asúa ${ }^{191}$, el cual proponía un sistema unicameral. Rechazada la Cámara profesional o corporativa, si se aceptó parcialmente la propuesta de Fernando de los Ríos de establecer Consejos Técnicos de aseguramiento, dentro la preocupación por la eficiencia de la actividad parlamentaria. En efecto el art.93 de la Constitución de la II ${ }^{\mathrm{a}}$ República definitivamente aprobada establecía que "Una ley especial regulará la creación y funcionamiento de los órganos asesores y de ordenación económica de la Administración, del Gobierno y de las Cortes. Entre estos organismos funcionará un Cuerpo Consultivo Supremo de la República en asuntos de Gobierno y Administración, cuya composición, atribuciones y funcionamiento serán regulados por dicha ley".

La proclamación de la II ${ }^{\mathrm{a}}$ República se realizó con un programa de paz y de justicia social. No sólo se mantuvieron las relaciones con la OIT, sino que estas se intensificaron. Albert

190 Véase POSADA, A.: Tratado de Derecho Política, edición crítica íntegra en un solo volumen, y estudio preliminar, "El pensamiento político-jurídico de Adolfo Posada" (pp. VII a CLXIII.), a cargo de J.L. Monereo Pérez, Granada, Comares (Col. Crítica del Derecho), 2003, págs. 639 y sigs. ("La República. La Constitución de 1931”). Posada destaca que la nueva Constitución de la segunda Repúblico se realizó bajo el influjo persistente de las nuevas necesidades sociales y las reivindicaciones de las clases que se estiman víctimas de la injusticia social y como consecuencia de las transformaciones reales e ideológicas características de la postguerra mundial. Aprecia, asimismo, el influjo, inmediato, sin duda, de la Constitución de Weimar. En la definición de la República (art. 1: "España es una República democrática de trabajadores de toda clase, que se organiza en régimen de Libertad y de Justicia", aprecia el influjo del elemento socialista en la elaboración de la Carta constitucional (Ibid., págs. 644-648). Con todo destacando que la Constitución es la "Ley suprema del Estado"; y más incisivamente: "La Constitución es la fuente primaria de nuestro Derecho constitucional escrito" (Ibid., pág. 650). Para Adolfo Posada la Constitución republicana es de tipo rígido, siguiendo la concepción de Bryce, y debe considerarse como el centro inspirador y propulsor del Derecho positivo, legislado o legislable. La Constitución es de una manera expresa la ley suprema, la "súper-ley" -como diría Hauriou (Précis de droit constitutionnel)-, con unas funciones esenciales: una, declarativa, relativa al espíritu con el cual se ha elaborado la Constitución y al que debe responder su aplicación y su interpretación, y otra, normativa, a la que deben adaptarse en su formación, organización y funcionamiento todas las instituciones del Estado de la República. En la Constitución Republicana de 1931, Adolfo Posada encuentra una influencia relativa de la Constitución de Weimar de 1919. Véase POSADA,A.: La nouvelle Constitution espagnole, París, Prefacio de JosehBarthélemy y B. Mirkine-Guetzevitch, 1932, capítulo VIII ("La Constitución en las Cortes Constituyentes"), apartado IV. Pero, al igual que la Constitución de Weimar, la Constitución de la II ${ }^{\mathrm{a}}$ República no podía ser calificada de socialista, por mucho que incorporase algunas tendencias propias de la socialización del Derecho y de la Economía. Es lógica social -pero no socialista- era destacada en el Discurso Preliminar pronunciado por Jiménez de Asúa (por mucho de que se hablase de "República de los trabajadores de toda clase"), "Discurso del Presidente de la Comisión Redactora del Proyecto" de Constitución republicana: "es una Constitución democrática, liberal, de un gran contenido social".

Las reflexiones hechas por Adolfo Posada en 1935, venían precedidas de un estudio más amplia -y más crítico-, POSADA, A.: La Nouvelle Constitution Espagnole (Le Régime Constitutionnel en Espagne.Evolution.-Textes.-Commentaires), París, Bibliothèque Constitutionnelle, Librairie du Recueil Sirey, 1932, donde, sin embargo, sí destacaba que la Constitución republicana de 1931 establecía "Los fundamentos constitucionales del "Derecho social"” (Capítulo IX. "La Constitución de 1931. Declaraciones y normas fundamentales", apartado VI.).

${ }^{191}$ JIMÉNEZ DE ASÚA, L.: Proceso histórico de la Constitución española, Madrid, Reus, 1932; JIMÉNEZ DE ASÚA, L.: La Constitución política de la democracia española, Santiago de Chile, Ediciones Ercilla, 1942.; JIMÉNEZ DE ASÚA, L.: La Constitución de la democracia española y el problema regional, Buenos Aires, Losada, 1946.; JIMÉNEZ DE ASÚA, L.: Anécdotas de las constituyentes, Buenos Aires, Cuadernos de Cultura Phac, 1942. 
Thomas -Director de la Oficina Internacional del Trabajo- ya tenía unas excelentes relaciones con los socialistas (antes y durante la Dictadura de Primo de Rivera ${ }^{192}$ ), la conexión entre Antonio Fabras Ribas, Largo Caballero y Albert Thomas era particularmente estrecha y de colaboración activa. Una vez que se proclamó la II ${ }^{a}$ República Albert Thomas felicitó personalmente a Largo Caballero y Fabra Ribas por sus nombramientos respectivos, como Ministro de Trabajo y Previsión y Director General de Trabajo. Luis Araquistáin sería nombrado representante del gobierno español en el Consejo de Administración de la OIT. Pero, además, el nuevo régimen democrático-republicano puso un mayor empeño en la implicación no sólo con la OIT, sino también con la Sociedad de Naciones desde el inicio de su instauración, de manera que la España democrática ponía de manifiesto su mayor compromiso integrador con las actividades de la Sociedad de Naciones en el marco de una nueva política exterior. En la dimensión sociolaboral de esa mayor integración se trazó todo un programa de ratificación de los convenios de la OIT (incluyendo la ratificación del convenio que establecía la jornada máxima de las ocho horas como prioridad). Proclamada la República, se decide enviar a Adolfo G. Posada como represente del Gobierno Republicano español a la reunión del Consejo de Administración. Ya resulta la presencia significativa como Delegados gubernamentales en las Conferencias Internacionales de Trabajo (1931-1938) de personalidades como Luis Araquistáin (1931, 1933), Juan Negrin (1933), Demófilo De Buen Lozano (1936), Leopoldo Palacios Morini ${ }^{193}$ (1936), el propio Fabra Ribas (1936, 1937 y 1938), León Martín Granizo (1936, suplente). O como Asesores Técnicos, Manuel Pedroso (1931, 1932), Carlos González Posada ${ }^{194}$ (1932, 1934), José Álvarez Ude (1934, 1935) León Martín Granizo (1932, 1933, 1934, 1935, 1936), José Ruiz Manent (1934. 1935), Alejandro Gallart Folch ${ }^{195}$ (1934).

La política republicana de ratificaciones sería especialmente impulsada por Largo Caballero, Fabra Ribas, pero también por Fernando de los Ríos y el equipo dirigente de la INP

\footnotetext{
${ }^{192}$ FABRA RIBAS, A.: La Organización Internacional del Trabajo, Prólogo de Albert Thomas, Director de la Oficina Internacional del Trabajo, Madrid, Javier Morata, 1929 (¿?). Fabra Ribas ya dejaba constancia de la influencia de la OIT en los países ibéricos e iberoamericanos (Ibid., págs. 179 y sigs.). Asimismo, MONEREO PÉREZ, J.L.: Los orígenes de la Seguridad Social en España. José Maluquer y Salvador, Granada, Comares, 2007, espec., págs. 181 y sigs., 227 y sigs. y 255 y sigs.

${ }^{193}$ MONEREO PÉREZ, J.L.: "Crítica social republicana y reformismo político-jurídico: Leopoldo Palacios Morini (1876-1952)", en Civitas. Revista española de derecho del trabajo, núm. 134 (2007), págs. 307358.

${ }^{194}$ MONEREO PÉREZ, J.: Carlos González Posada (1890-1948): La teoría del seguro social y su institucionalización en España, en Revista de Derecho de la Seguridad Social Laborum, núm. 13 (2017), págs. 313-334.

${ }^{195}$ MONEREO PÉREZ, J.L. y PELÁEZ, M.J.: “Alexandre Gallart Folch (1893-1972)”, en Diccionario crítico de juristas españoles, portugueses y latinoamericanos, Zaragoza-Barcelona, 2005, Vol. I, págs. 337339, núm. 332; GALLART FOLCH, A.: Las convenciones colectivas de condiciones de trabajo en la doctrina y en las legislaciones extranjeras y españolas, edición y estudio preliminar, "Teoría jurídica del convenio colectivo: su elaboración en la ciencia del Derecho", a cargo de J.L. Monereo Pérez, Granada, Comares (Col. Crítica del Derecho), 2000.
} 
(Inocencio Jiménez ${ }^{196}$, y el gran Adolfo G. Posada ${ }^{197}$, que había sido repuesto en su cargo ${ }^{198}$. La idea es que se ratificaran todos los convenios de la OIT aprobados en la Conferencia General de la OIT y pendientes de ratificación por nuestro país, por un lado, y por otro, preparando la legislación interna nacional para garantizar su aplicación efectiva ${ }^{199}$. El art. 75 del Proyecto de Constitución Republica (votado en las Cortes en la sesión de 3 de noviembre de 1931, que en el texto definitivo pasaría a ser el art. 65 de la Constitución de la República Española de 1931200), contenía una obligación constitucional de autosometimiento al orden internacional. En efecto, ya el art. 65 de la Constitución es redactado con el siguiente tenor: "Todos los Convenios internacionales ratificados por España e inscritos en la Sociedad de las Naciones y que tengan carácter de ley internacional, se considerarán parte constitutiva de la legislación española, que habrá de acomodarse a la que en aquéllos se disponga. Una vez ratificado un Convenio internacional que afecte a la ordenación jurídica del Estado, el Gobierno presentará, en plazo breve, al Congreso de los Diputados, los proyectos de ley necesarios para la ejecución de sus preceptos. No podrá dictarse ley alguna en contradicción con dichos Convenios, si no hubieran sido previamente denunciados conforme al procedimiento en ellos establecido. La iniciativa de la denuncia habrá de ser sancionada por las Cortes"201.

No obstante el proceso fue algo más lento de lo esperado, porque, entre otras cosas, no debe olvidarse que las ratificaciones de los Convenios de la OIT exigían modificaciones y adaptaciones previas de la legislación nacional y esto planteaba problemas de tramitación y de obtención de los consensos necesarios en las Cortes Generales. La etapa de más intensidad las ratificaciones coincide significativamente con la II ${ }^{a}$ República española, sobre todo en su momento inicial, con las medidas sociales de Largo Caballero, y su momento

\footnotetext{
196 Sobre su pensamiento, puede consultarse MONEREO PÉREZ, J.L.: "Inocencio Jiménez Vicente (9 de noviembre de 1876-27 de abril de 1941): Artífice del desarrollo del Instituto Nacional de Previsión y de la previsión social durante la Dictadura de Primo de Rivera y la Segunda República", en Revista de Derecho de la Seguridad Social Laborum, núm. 20 (2019), págs. 267-301. Constancia breve de su quehacer en INP.: "Homenaje a la memoria de Don Inocencio Jiménez Vicente celebrado en Zaragoza el 10 de octubre de 1942”, Madrid, Publicaciones del Instituto Nacional de Previsión, núm. 555 (1943). Sobre la legislación de previsión social, alcanzando a la II ${ }^{a}$ República, véase GALLART FOLCH, A.: Derecho Español del Trabajo, Prólogo de Pedro Sangro y Ros de Olano, Barcelona-Madrid-Buenos Aires-Río de Janeiro, 1936, págs. 348 y sigs. ("La previsión social" como instrumento de protección de los trabajadores fuera del trabajo).

${ }^{197}$ MONEREO PÉREZ, J.L.: La reforma social en España: Adolfo Posada, Madrid, Ministerio de Trabajo y Asuntos Sociales, 2003.

${ }^{198}$ MONEREO PÉREZ, J.L.: La reforma social en España: Adolfo Posada, Madrid, Ministerio de Trabajo y Asuntos Sociales, Madrid, 2003.

${ }^{199}$ Véase la excelente investigación de CUESTA BUSTILLO, J.: Una esperanza para los trabajadores. Las relaciones entre España y la Organización Internacional del Trabajo (1919-1939). Vol. I, Madrid, Consejo Económico y Social de España, 1994, págs. 263 y sigs.

200 "Gaceta de Madrid", núm. 344, de 10 de diciembre de 1931, páginas 1578 a 1588. Cortes Constituyentes. BOE-A-1931-10008.

${ }^{201}$ Por su parte, el art. 76 de la Constitución de la República (relativo a determinadas competencias del Presidente de la República) incluía un párrafo e), a cuyo tenor: "Los proyectos de convención de la organización Internacional del Trabajo serán [imperativo categórico] sometidos a las Cortes en el plazo máximo de un año, a partir de la clausura de la Conferencia que les ha votado. Este plazo podrá ser de 18 meses en circunstancias excepcionales. Tan pronto como los textos de los convenios hayan sido aprobados por el Parlamento, el Presidente de la República firmará la ratificación, que será comunicada, a efectos de registro, a la Sociedad de Naciones".
} 
final, con las ratificaciones tardías de 1938. Es revelador el hecho de que en 1939, cuando el gobierno republicano marcha de España, éste es el país que había conseguido el mayor nivel de ratificaciones hasta el momento, esto es, un total de 34; le sigue Bélgica, con 33. De modo incidental, es de realzar que, en la actualidad, nuestro país es el primero de la lista de Estados Miembros de la OIT en número de ratificaciones de los convenios de esta organización internacional de la cual emana un Derecho internacional uniforme ${ }^{202}$. Destáquese que los Convenios de la OIT relativos a las libertades y derechos fundamentales presuponen un orden democrático constitucional pluralista. Por lo demás, por sus propios fines y estructura interna tripartita, la OIT nunca fue un organismo internacional que pudiera ser calificado como revolucionario en el sentido fuerte de la expresión (Es suficiente una lectura de la Parte XIII del Tratado de Versalles, que acogía la Constitución de la OIT, con un Preámbulo extraordinariamente expresivo de su función institucional y fines político jurídicos $)^{203}$. De ella -con base el principio constitutivo del tripartismo- se busca implantar una legislación avanzada de compromiso social entre Gobiernos y las organizaciones sindicales y empresariales más representativas de los Estados Miembros. Y a esto es lo que se sometía explícitamente la Constitución de la II ${ }^{a}$ República, y por extensión inevitable - y lo fue por imperativa- el Gobierno republicano-socialista del primer bienio.

Pero también -y esto es todavía más relevante desde el punto de vista estrictamente jurídicotodo esto cristalizó en el texto definitivo de la Constitución de la II ${ }^{a}$ República contenía esa misma regulación preceptiva en el art. 65 (en relación con el art.76 de la referida Norma Fundamental) ${ }^{204}$. Como se puede apreciar esta sólo norma ya garantiza el sometimiento al orden internacional y el carácter democrático-social de la República Española, de manera que salvo reforma constitucional el régimen democrático-social y pluralista de partidos y organizaciones profesionales quedaba plena e indiscutiblemente garantiza en la propia Norma Fundamental constitutivo y central de nuestro ordenamiento jurídico general. Esto refleja que en sí misma Constitución de la II ${ }^{a}$ República formalizaba una democracia

\footnotetext{
${ }^{202}$ Véase CUESTA BUSTILLO, J.: Una esperanza para los trabajadores. Las relaciones entre España y la Organización Internacional del Trabajo (1919-1939). Vol. I, Madrid, Consejo Económico y Social de España, 1994, passsim. .

${ }^{203}$ Es suficiente retener la exposición del que ya es todo un libro clásico en la materia, VALTICOS, N.: Derecho Internacional del Trabajo (1970), trad. Ma . José Triviño, Madrid, Tecnos, 1977, espec., Capítulo II ("La creación de la OIT"), págs. 52-115.

${ }^{204}$ Conforme al art. 76 de la Constitución de la II ${ }^{a}$ República (1931): "Corresponde también al Presidente de la República: [...] e) Negociar, firmar y ratificar los Tratados y Convenios internacionales sobre cualquier materia y vigilar su cumplimiento en todo el territorio nacional. Los Tratados de carácter político, los de comercio, los que supongan gravamen para la Hacienda pública o individualmente para los ciudadanos españoles $\mathrm{y}$, en general, todos aquellos que exijan para su ejecución medidas de orden legislativo, sólo obligarán a la Nación si han sido aprobados por las Cortes. Los proyectos de Convenio de la organización internacional del trabajo serán sometidos a las Cortes en el plazo de un año y, en caso de circunstancias excepcionales, de dieciocho meses, a partir de la clausura de la Conferencia en que hayan sido adoptados. Una vez aprobados por el Parlamento, el Presidente de la República subscribirá la ratificación, que será comunicada, para su registro, a la Sociedad de las Naciones. Los demás Tratados y Convenios internacionales ratificados por España, también deberán ser registrados en la Sociedad de las Naciones, con arreglo al artículo 18 del Pacto de la Sociedad, a los efectos que en él se previenen. Los Tratados y Convenios secretos y las cláusulas secretas de cualquier Tratado o Convenio no obligarán a la Nación”.
} 
constitucional autosometida al estándar mundial multinivel en construcción de garantía jurídica de los derechos fundamentales. No era una Constitución jurídica que consagrara nada parecido a un orden "revolucionario", aunque, sin duda, estaba abierta a distintas opciones políticas legítimas, siempre que respetasen las bases y pilares estructurales del sistema político y jurídico edificado por el propio Texto Fundamental pluralista.

La legislación laboral y de protección social pública en su conjunto constituyó un avance extraordinario en la dirección de realizar el programa de construcción de un verdadero Derecho Social del Trabajo y de la Seguridad Social de base constitucional-garantista, es decir, como parte y especificación de la constitución democrático-social del trabajo ${ }^{205}$. Es entonces es cuando se puede hablar con propiedad de la existencia jurídica de un Derecho Social del Trabajo y de la Seguridad Social como una rama singular o sector diferenciado dentro del ordenamiento jurídico constitucional asentado en sus principios, valores, y normas comunes en la Constitución jurídica. Para ello no era suficiente que la Constitución garantizara los derechos sociales de desmercantilización, sino que estos fuesen -como en parte se logró- garantizados en su efectividad a través de la legislación estatal y de la actuación de la Administración del Trabajo, dentro de cual adquiere un protagonismo innegable el Ministerio de Trabajo y la Inspección de Trabajo y Previsión Social. De ahí el mandato constitucional ex art. 46 de la Constitución Republicana.

Hay que tener en cuenta que el constitucionalismo social de la primera postguerra mundial (1919-1938) es, en cierto modo, un intento de formalizar o racionalizar en la norma fundamental todo un proceso de revisión social y democrática que los regímenes políticos liberales habían experimentado de hecho en el último siglo, junto con el intento de instaurar una nueva modalidad del Estado: el llamado Estado social de Derecho, llamado a corregir los efectos disfuncionales de la sociedad industrial competitiva. Para ello era necesario un replanteamiento de las relaciones entre la sociedad política y la sociedad civil, entre el Estado y la sociedad en la línea de suprimir la inhibición del Estado frente a determinados problemas económicos y sociales: el Estado deviene de Estado gendarme a Estado gestor, a fin de desempeñar una función reguladora e interventora en los procesos económicos y en los conflictos propios del naciente sistema neocapitalista. En esta línea del constitucionalismo de entreguerras se inscribe la Constitución española de 1931, que dispensa una protección especial al trabajo y establece todo un programa jurídico laboral de la República que ha de

${ }^{205}$ En este sentido, MONEREO PERÉZ, J.L.: Derechos sociales de la ciudadanía y ordenamiento laboral, Madrid, Consejo Económico y Social de España, 1996, espec., págs. 116 y sigs., y 134 y sigs.; MONEREO PÉREZ, J.L.: "Las (pre)supuestos histórico-institucionales de la Seguridad Social en la constitución social del trabajo", en ROJAS RIVERO, G. (Coord.): Orígenes del contrato de trabajo y nacimiento del Sistema de Protección Social, Albacete, Bomarzo, 2012, págs. 203-218.; MONEREO PERÉZ, J.L.: Fundamentos doctrinales del Derecho Social, Madrid, Trotta, 1999, espec., págs. 191 y sigs. (sobre "Derecho social, socialismo democrático y constitución jurídica de la clase trabajadora", "Reformas social y constitución del trabajo" y "La combinación de status y contrato en la "constitución del trabajo). 
ser garantiza eficazmente por el Estado en desarrollo de las previsiones y mandatos constitucionales (cfr. artículos 39, 39 y 46, especialmente) ${ }^{206}$.

Por otra parte, Adolfo Posada entiende que la superación del Estado liberal individualista exige la realización de un proceso de democratización para que el Estado sea efectivamente expresión de la comunidad, y sea esta quien ostente el poder ${ }^{207}$. Sin embargo, Posada defiende una "democracia orgánica y jerarquizada"208, que sin negar los principios de sufragio universal y de representación política ${ }^{209}$, permite agregar a la esfera política a los grupos sociales y corporaciones de intereses, los cuales han de ser representados institucionalmente en una Cámara profesional o parlamento industrial. Esta representación de intereses sería elegida por vía corporativa indirecta. Pero ese régimen democrático orgánico debe ser gobernado por las personas más preparadas y capaces de actuar. Estas élites serían los candidatos elegidos en unas elecciones democráticas. Por consiguiente se rechaza toda forma de dictadura, toda forma de gobierno que no sea efectivamente objeto de control por parte de los ciudadanos ${ }^{210}$. El compromiso con la democracia de Posada no puede ponerse en duda, sin embargo esto no significa que se ignoren las críticas en muchos casos excesivas de Posada al Parlamento, aunque es cierto que muchas de ellas estaban condicionadas por el contexto histórico en las que se produjeron: por el "pseudoparlamentarismo" de la Restauración y la ausencia en este régimen de mínimas garantías democráticas y de control jurisdiccional de la actividad pública, el "Estado real" del caciquismo antes denunciado por Joaquín Costa en términos de "constitución real" que se impone al "Estado oficial", a la "constitución formal"211. Pero, siempre y no sólo en su época de madurez, Posada consideró que el Parlamento, con todas sus imperfecciones, es elemento imprescindible en una teoría democrática del Estado. De ahí la defensa de la

\footnotetext{
${ }^{206}$ MONEREO PÉREZ, J.L.: Derechos sociales de la ciudadanía y ordenamiento laboral, Madrid, Consejo Económico y Social de España, 1996, págs. 123-125.

${ }^{207}$ Véase POSADA,A.: Teoría social y jurídica del Estado, cit., pág.262.

${ }^{208}$ POSADA,A.: "Actitud ética ante la guerra y la paz", cit., pág.78.; POSADA,A.: La crisis del Estado y el Derecho Político, Madrid, C.Bermejo, 1934, págs.142-143, y Lección 10a , págs.144 y sigs. Desde el pensamiento del catolicismo social se había defendido la instauración de un régimen corporativo en fecha próxima a la proclamación de la República e incluso una vez instaurada la II ${ }^{a}$ República. En este sentido resultan paradigmáticas las opiniones de JORDANA DE POZAS,L.: "El régimen corporativo como sistema de reforma social", en Problemas sociales candentes, Subirana, 1930; GALLACH Y FOLCH,A.: "Orientaciones corporativas de la Legislación del trabajo", en La crisis moral, social y económica del Mundo, Madrid, 1934.

${ }^{209}$ En la Base V ("Derechos de los españoles") para la Constitución Política de España (1931) se reconoce como condición de su plena ciudadanía de los españoles: "El sufragio político en las condiciones que las leyes establezcan, acomodándose éstas a las normas de la base siguiente". Base V ("El sufragio"). Cfr. POSADA,A.: La reforma constitucional, cit., pág. 217.

${ }^{210}$ Véase POSADA,A.: La crisis del Estado y el Derecho político, cit.,págs.159 y 169.

${ }^{211}$ Es el caso de algunos obras de juventud, como POSADA,A.: Estudios sobre el régimen parlamentario en España (1891), Est.prel., de F.Rubio Llorente, cit., pág.LXXXIII. Respecto de ella hace notar Rubio Llorente que "Sea en razón de su origen, sea porque el joven profesor no tiene todavía la mesura del maestro, el libro de Posada tiene sin embargo un tono más radical que el de Azcárate. La condena del Parlamento, sobre todo en algunos pasajes de la carta dedicatoria y de la Introducción resulta poco matizada y su juicio sobre la labor del Parlamento, que es el que sobre todo ha tenido en cuenta al escribir, es injusto. Son las Cortes que nacen de las elecciones celebradas el 4 de abril de 1886, las únicas de la Restauración que concluyeron por expiración de su mandato". También, poniendo de relieve la realidad del caciquismo frente al "Estado oficial español", en el sentido de Costa, POSADA,A.: "Prólogo", en España en crisis, Madrid, Editorial Caro Raggio, 1923, pág.10.
} 
institución parlamentaria que late en todo su extensa obra ${ }^{212}$. En realidad, el Parlamento de la Restauración no era más que una representación teatral, un instrumento del Gobierno, cuya voluntad acatan los parlamentarios en general dócilmente, pues número de ellos son funcionarios y todos esperan obtener de él favores. Los grandes agentes y beneficiarios del sistema son, por supuesto, los caciques, en alianza con la Administración centralizada, a la que utilizan y por la que son utilizados. Políticos profesionales que no tienen más horizontes que los estrechos de su propio feudo ${ }^{213}$. También es un régimen que convenía en no poco a los intereses de la burguesía industrial, la cual podía actuar libremente al amparo de la protección del Estado conservador. El Estado de la Restauración era un "Estado del capital" representativo de intereses inmediatos de la burguesía de la oligarquía terrateniente. Es una falacia pensar que sólo lo era respecto de los intereses de esta última. Posa trata de renovar el liberalismo democrático, pero miraba con desconfianza la inclinación democrática socializante que presidía la Constitución de la II ${ }^{\mathrm{a}}$ República $^{214}$. En realidad, cabría hablar más exactamente de que la Constitución republicana era una síntesis interesante de las nuevas tendencias del Derecho constitucional democrático de la postguerra ${ }^{215}$.

\section{Transformación los mecanismos de representación en el Estado democrático: representación política y representación de intereses específicos ("parlamento social o cámara social"')}

Para Posada la crisis de la representación política exige una revisión de los fundamentos de la representación política. Es el problema de la representación política y social en el Estado. En su opinión la revisión ha de hacerse con un doble propósito: a) Incorporar a la estructura constitucional, es decir, a las instituciones más específicamente representativas -las Cámaras de nuestras Cortes-, los elementos individuales y "sociales" -sindicales, corporativos, agrupaciones-, a fin de que tengan voz y el influjo debido, al lado del interés general, los intereses de carácter colectivo que hayan logrado una organización específica. Según Posada la reforma social y el sindicalismo (al igual que otros pensadores como León Duguit) son elementos centrales de la tarea del Estado moderno; y, en cuanto tales, como problemas de Estado, objeto de estudio. El Estado no podía ignorar ya la existencia política de dos realidades igualmente humanas: la individual y la social. En realidad, la vida imponía nuevas

\footnotetext{
${ }^{212}$ En este sentido, POSADA,A.: España en crisis. La política, Madrid,1923; ID.: La reforma constitucional, cit., pág. 25 .

${ }^{213}$ RUBIO LLORENTE,F.: "Estudio preliminar" a la obra de POSADA,A.: Estudios sobre el Régimen Parlamentario en España, cit., pág.LXXXV.

${ }^{214}$ Véase la interpretación, a menudo amarga, del nuevo texto constitucional, POSADA,A.: La nouvelle Constitution espagnole, París, Prefacio de Joseh-Barthélemy y B. Mirkine-Guetzevitch, 1932. Sin embargo, Posada no ve en la Constitución republica la recepción plena del modelo de Weimar, sino relativa (Ibid.,págs.115 a 124). Pero la mayoría de los tratadistas del período la enmarcan dentro de la nueva orientación del constitucionalismo social de Weimar (Constitucionalismo democrático-social con Estado Social de Derecho). Es el caso de GUILLERM,A.: La Constitution republicaine espagnole du 9 Décembre 1931, París, 1933, pág.8.

${ }^{215}$ Esta es la opinión de MIRKINE-GUETZEVITCH: "La nouvelle Constitution espagnole", en Revue Politique et Parlamentaire, janvier, 1932, pág.141.
} 
exigencias económicas y éticas, desbordando las fórmulas políticas y jurídicas del régimen constitucional del Estado liberal ${ }^{216}$. La forma de Estado constitucional social reflejaría esa implicación constitucional y ética en la realización de la justicia social y en armonización jurídica de la esfera individual y social del hombre (como ciudadano, como productor, como miembro de asociaciones, sindicatos, etcétera). b) Impedir que los intereses organizados los profesionales, los de la producción-, con el desate de egoísmos que supone su creciente influjo, ahogue la voz del interés general, que no es una abstracción, sino la realidad misma de la vida nacional, la que afecta al hombre como tal -económicamente consumidor y políticamente ciudadano-, interés general que en una democracia organizada tendría su órgano específico más inmediato en el ciudadano-elector ${ }^{217}$. Con base a la consideración pluralista de la ciudadanía, en la que el hombre se encuentra socialmente situado en sus formaciones sociales Posada fundamenta la necesidad de que la representación no sólo sea política general, sino también, y complementariamente, de carácter profesional ${ }^{218}$. Ello sintoniza perfectamente con su configuración organicista del Estado ${ }^{219}$, pues "siendo el Estado la comunidad políticamente organizada, esas nuevas actividades sociales se producen como verdaderas fuerzas específicamente constituidas para la acción defensiva y ofensiva de los intereses o fines colectivos diferenciados, distintos, parciales en su diferenciación. Las organizaciones que se constituyen desempeñan verdaderas funciones sociales; pero, por necesidad ineludible, las desempeñan dentro del Estado, de sus Estados, y han de reclamar -y reclaman- que se les permita ejercer un influjo, que puede ser legítimo o abusivo, en el Estado mismo.

Pero esa presencia no puede suponer una ruptura revolucionaria en el proceso político del régimen representativo. Se trata, exclusivamente, de incorporar a una Constitución política el hecho de la diferenciación social en actividades, representativas de intereses; y, en atención a ello, de construir formas de gobierno más en consonancia con la presencia en el Estado de las nuevas fuerzas o actividades sociales ${ }^{220}$. Él entiende que es preferible la

\footnotetext{
216 POSADA, A.: Teoría social y jurídica del Estado. El sindicalismo, Buenos Aires, Librería J. Méndez ed., 1922, pág. 105.

${ }^{217}$ POSADA,A.: La reforma constitucional, cit., págs.105-106.

${ }^{218}$ La proyección pluralista de la ciudadanía confluye con la configuración que Gurvitch había trazado en 1932 en su conocida obra la L'idée du droit social, y más tarde en su propuesta de Declaración de derechos sociales, de 1946 (Existe traducción, edición y estudio preliminar a cargo de J.L. Monereo Pérez y A. Márquez Prieto, Granada, Comares (Col. Crítica del Derecho), 2005. No deja de ser en gran medida anticipatorio el planteamiento de Gurvitch sobre la configuración de la ciudadanía social y su proyección constitucional, aunque con apoyo en la fórmula todavía debilitada que proporcionara la Constitución de Weimar de 1919. Véase MONEREO PÉREZ,J.L.: "Pluralismo y Derecho social", Est.prel., a GURVITCH,G.: Elementos de sociología jurídica, Granada, Comares (Colección Crítica del Derecho), 2001, págs.XIII-CXLVI .

${ }^{219}$ Señala que un estudio del pensamiento político moderno nos haría ver cómo la doctrina se ha adelantado a los hechos al distinguir Sociedad y Estado y al afirmar que aquélla no es un agregado de individuos, sino organismo (Spencer) constituido merced al enlace íntimo de actividades sociales diferenciadas (Krause, Ahrens, Schäffle, Gierke, Giner...). Pero ahora ya la nueva estructura de las realidades sociales ha provocado serio movimiento entre los teóricos del Estado, quienes, a la vez que explican la radical transformación de las sociedades, afirman la necesidad de construir formas de gobierno acordes con la presencia en el Estado de las nuevas fuerzas o actividades sociales. Cfr. POSADA,A.: La reforma constitucional, cit., págs.115-116. Posada nos explicita aquí sus propios fundamentos doctrinales y su entronque con el modo de pensar organicista.

${ }^{220}$ POSADA,A.: La reforma constitucional, cit., págs.112, 115 y 116.
} 
integración diferenciada de los intereses en el sistema político democrático a que las organizaciones de intereses presiones desde fuera de la estructura oficial ("Estado oficial") sobre los poderes públicos. Es por tanto necesario caminar hacia la representación de los intereses en el régimen político. La experiencia histórica (que Posada oportunamente recoge la habida hasta su época) muestra que no existe un único modelo para incorporar los intereses socialmente estructurados al "régimen de gobierno" ${ }^{221}$. Posada se inclina por la constitucionalización de la representación política de los intereses sociales a través de su incorporación a las cámaras legislativas ${ }^{222}$. Para Posada la revisión constitucional de la representación política y de sus instituciones no puede realizarse abstractamente, pues debe producirse atendiendo a la realidad social, la cual ha de recogerse y reflejarse en la organización estatal. En este sentido se debe partir de dos hechos capitales: por un lado, la democratización de la vida social, que se revela y afirma, mediante el creciente influjo de dichas masas, con sus anhelos de bienestar y sus fuerzas, a la larga, irresistibles y, a menudo, con claras inclinaciones a la "acción directa"; y, por otro, la existencia, en todos los ámbitos de la sociedad, de intensas tendencias hacia la organización en "grupos", determinadas por la atracción del fin común. Estos dos factores provocan un movimiento que determina "el paso de la democracia gregaria hacia la democracia socialmente, y que, a la larga, podrá convertirse en "orgánica". He aquí su apuesta por una "democracia organizada u orgánica", que debería ser la negación de toda especie de dictadura ${ }^{223}$, y de exclusivismo de clase, dominación de partido o simplemente de la acción arbitraria del gobernante detentador del Poder $^{224}$. Debe respetar la esencia la democracia representativa parlamentaria y el conjunto de los derechos y libertades fundamentales, condiciones de vida de las personas. De lo que se trata es de conjugar el "hombre abstracto" con el "hombre concreto y real", como individuo físico de necesidades positivas, en el ciudadano del Estado nacional moderno, mediante el logro de un bienestar mínimo que alcanzará cada cual en parte por obra de su libertad, jurídicamente regulada. Posada postula el compromiso constitucional para garantizar ese bienestar mínimo, y con el derecho a la existencia humana digna, que el autor pudo apreciar en el plano doctrinal en autores como Anton Menger y Otto von Gierke, que sin duda son los fundadores originarios del Derecho social contemporáneo ${ }^{225}$. Se había

\footnotetext{
${ }^{221}$ Esas experiencas que detecta van desde la participación en órganos que no se estiman de soberanía, a través de la forma de Consejo económico, o incluso el que fuera nuestro Instituto de Reformas Sociales, fundado en 1903-1904, y destruído por la dictadura en 1924, hasta la creación de una Cámara legislativa profesional. Véase POSADA,A.: La reforma constitucional, cit., págs. 124 y sigs.

${ }^{222}$ Posada recuerda la inclusión -bajo la inspiración de Giner- en la Constitución española de 1876, la cual al organizar el Senado (Título III), habla, en el número tercero del art.20, de senadores elegidos por las "Corporaciones del Estado y mayores contribuyentes". Pero recoge experiencias en la legislación extranjera de la efectivamente incorporación de esas cámaras legislativas profesionales. cfr. POSADA,A.: La reforma constitucional, cit., págs.130 y sigs.

${ }^{223}$ Posada critica severamente, y sin concesiones, tanto la dictadura del proletariado como el fascismo. Según él, "el fascismo es obra de burguesía, y lo acarician, como el mejor de los métodos para prolongar su dominación, las burguesías reaccionarias del mundo, y, para afirmar su condición agresiva, los nacionalismos desatados de todos los pueblos, temerosas las primeras ante el avance del proletariado y ante el "peligro ruso", y los segundos, dominados aún por la pasión del odio insensato de nación contra nación, engendrador de las guerras". Cfr. POSADA,A.: La reforma constitucional, cit., pág.134.

${ }^{224}$ POSADA,A.: La reforma constitucional, Madrid, Librería de Victoriano Suárez, 1931, págs.132 y sigs.

${ }^{225}$ Véase MONEREO PÉREZ,J.L.: Reformismo social y socialismo jurídico, Est.prel., a MENGER,A.: El
} 
constatado los límites intrínsecos de la concepción liberal individualista de los derechos, reflejada en gran medida en la noción abstracta de sujeto jurídico (y de ciudadano). En efecto, bajo el prisma liberal de la abstracción jurídica del sujeto, "el orden legal, expresión de la organización político-jurídica de la sociedad, se separa del orden real, expresión de la actividad autónoma de los individuos empíricos"226. Posada y en general los artífices del reformismo social que la satisfacción de ciertas necesidades podría articularse en forma de derechos social fundamental, atendiendo a las condiciones reales de la existencia como elemento necesario para el libre desarrollo de la personalidad humana.

Es necesario, pues, articular un sistema de doble representación: la representación política y la representación social en dos cámaras separadas del parlamento. Vuelve a reclamar la concepción orgánica de la sociedad: en ella la compenetración armónica de las actividades sociales, diferenciadas en los grupos por otra, en buena parte, de la compenetración, de la homogeneidad fundamental del elemento humano -raíz democrática- que se sintetiza en los individuos, es lo que induce a reconocer y afirmar la existencia de las naciones como entidades sustantivas, distintas de sus Estados, imponiendo la total revisión del régimen de la representación política, a fin de que ésta responda a las exigencias positivas de la realidad social que palpita en la vida de las naciones modernas, que no son, en verdad, meros agregados de hombres -democracia atomística- ni simples conglomerados de hombres insaciables, de espíritu oligárquico ${ }^{227}$. La articulación de estas dos formas de representación puede permitir, en su opinión, convertir la democracia niveladora -gregaria, igualitaria- en democracia orgánica. Pero la representación de intereses -dirá con Giner y Schäffle ${ }^{228}$ - debe tener su representación al lado de la "masa elemental" a que el sufragio universal

\footnotetext{
Derecho civil y los pobres, Granada, Comares (Colección Crítica del Derecho), 1998.

${ }^{226}$ Cfr. BARCELLONA,P.: I soggetti e le norme, Milán, Giuffrè, 1984, pág.93.

${ }^{227}$ POSADA,A.: La reforma constitucional, cit., pág.139. Respecto al "derecho público del Estado" Ahrens había expresado de modo conciso pero revelador la concepción organicista de la sociedad y del Estado: el organicismo de la sociedad está fundado en la naturaleza del hombre y tiende á constituirse en el desarrollo progresivo de los pueblos. La organización ha llegado á ser la divisa de nuestra época; el sistema exclusivo de individualismo atomístico y de libertad abstracta se muestra impotente para la reconstrucción de la sociedad; pero la reorganización sucesiva no puede establecerse sino con relación á los principios de la libertad, de la autonomía del self-government y de la coordinación orgánica de las diversas esferas de la actividad humana, formando, en el seno de cada pueblo, un sistema federativo de todas las esferas de vida y de cultura, y presentando el desarrollo sucesivo y siempre más armónico del organismo ético de la humanidad. Cfr. AHRENS,E.: Curso de Derecho Natural ó de Filosofía del Derecho, cit., pág.668.

${ }^{228}$ Giner mostró una gran confluencia de pensamiento con Schäffle al cual dedicó una especial atención en su libro GINER DE LOS RÍOS,F.: Persona social. Estudios y fragmentos, Madrid, Librería General de Victoriano Suárez, 1899, págs. 85 a 133, subrayando su vinculación en numerosas cuestiones con Krause.
} 
corresponde $^{229}$. En esta argumentación se pone de manifiesto las connotaciones elitistas ${ }^{230}$ de su visión de la "democracia orgánica". Para él no existe incompatibilidad entre el carácter naturalmente orgánico de la vida social, sistema de funciones distintas bajo una ley de unidad -división social del trabajo humano-, y las esencias que definen la democracia. Por su parte, el carácter jerarquizado de la democracia no hace referencia, en su opinión, a una determinación autoritaria (posición de Mussolini) del valor de las fuentes sociales, y menos aún, a una imposición coactiva -dictatorial- de los grados jerárquicos en cada formación social: No; la jerarquización en la democracia -no demagógica, ni dictatorial-, entraña la labor espontánea y continuada de la interna diferenciación funcional, con el proceso natural de la formación de las élites representativas y directoras, y el de la determinación social de la escala de valores en cada momento. La visión elitista se acentúa cuando añade a continuación: el orden democrático debe realizar la selección de los mejores (el subrayado es suyo), tan necesaria en una democracia organizada"231. El problema es que cuestiona en cierto modo el principio de la soberanía popular: "considerada polémicamente la noción de la democracia, no puede definirse desde el punto de vista político, según generalmente se hace como aquel Estado donde reina la voluntad del pueblo o la voluntad de la mayoría", porque mi noción de la democracia se opone a la idea de la contextura gregaria y numérica del Pueblo, sujeto activo de todo régimen democrático. En realidad, entiende que para que

\footnotetext{
${ }^{229}$ POSADA,A.: La reforma constitucional, cit.,págs.139-140. No llega Posada a criticar en sí, como lo hiciera Giner, el sufragio universal. Recuérdese que para Giner el sufragio, como intervención directa en la gestión oficial del Estado social, no puede ser ejercido más que por aquellos de sus miembros que poseen la plenitud de su facultad de obrar. De ahí el profundo error que encierra el llamado sufragio universal, en tanto que se halla necesariamente limitado el ejercicio de este poder, no debiendo hacer uso de él el loco, el menor, el delincuente, el que no ofrece garantías de aptitud intelectual y moral para el bien público. Cfr.GINER DE LOS RÍOS,F.: La política antigua y la política nueva, en Estudios Jurídicos y Políticos, Obras Completas, t.V, Madrid, Espasa-Calpe, 1921. Pero, al tiempo, lo que ha permanecido del pensamiento de Giner no es tanto su filosofía política como su filosofía moral, la cual ha ejercido un influjo perdurable en quienes siempre defendieron la democracia. Véase DÍAZ,E.: La filosofía social del krausismo español, Madrid, Cuadernos para el Diálogo, 1973, págs.113 y sigs.

${ }^{230}$ Las reticencias vienen de antiguo, aunque cabe decir que en una época donde se había desvirtuado gravemente los principios de la democracia. Ahrens hacía notar que el principio democrático de elección, tal como se practica en la forma del sufragio universal, se manifiesta en sus efectos más apreciables por la elección de sus representantes de la asamblea legislativa. Estas elecciones han puesto en evidencia el principio filosófico general, que no admite ninguna excepción, de que los efectos son siempre conforme á las causas; por esto vemos que desde luego el sufragio universal, al llamar á la elección á aquellos cuya inteligencia está menos cultivada y que conocen su incapacidad para poder guiarse con seguridad, los entrega en manos de los partidos que en los Estados-Unidos se ocupan de los asuntos políticos como de cualquiera otro negocio de especulación, y que ha establecido para las luchas electorales una organización casi militar y perfectamente disciplinada, por la cual el Estado, organizado por sí tan débilmente en órganos variables sin cesar, es presa de los que han sabido explotar con más habilidad las pasiones populares. Además, el resultado de las elecciones se ha desprestigiado manifiestamente hace unos treinta años. Cfr. AHRENS,E.: Curso de Derecho Natural ó de Filosofía del Derecho, cit., págs.590-591. De ahí, se comprende explicativamente, la propuesta, muy frecuente en la familia krausista, de completar la democracia puramente cuantitativa con una democracia cualitativa. Este modo de pensar enlaza también en Ahrens con la idea de representación por intereses sociales, partiendo como él lo hace de que el sistema de representación "por cabeza" o por sufragio universal estricto constituye un sistema abstracto, individualista, atomístico, que parte de la noción abstracta de ciudadano, realizada de una manera igual en cada miembro de la comunidad política, y llamando al ciudadano como tal a la elección, sin tener en cuenta todas sus demás cualidades importantes, todas las relaciones reales, esenciales y permanentes que tiene en el orden social (Ibid.,págs.600 y sigs., respecto a los "modos para la formación de la representación ó sistemas de elección").

${ }^{231}$ POSADA,A.: La crisis del Estado y el Derecho Político, Madrid, C.Bermejo, 1934, pág.156.
} 
la noción de la democracia resista al análisis, ha de expresar la realidad política de un Pueblo, que concebimos como una creación histórica, obra nunca terminada de un proceso, y que constituirá un Estado, si es capaz de afirmarse como una personalidad colectiva, dotada de un espíritu propio, verbigracia, espíritu nacional ${ }^{232}$.

Sin embargo, moviéndose en una zona ciertamente peligrosa y harto contradictoria en la argumentación (realizada al límite), estima que no hay contradicción entre la concepción democrática del Estado y la explicación orgánica del mismo; no se debe rechazar como incompatible con los partidos, y por ende, con la democracia, la consagración política y jurídica en el Estado, de la diferenciación social de los intereses generales de los grupos humanos funcionales. Es más, si los partidos son los "órganos" de opinión del cuerpo político, del Estado, los grupos sociales (sindicatos, asociaciones, núcleos locales), son los órganos del cuerpo social ${ }^{233}$. La realidad histórica de su tiempo pronto vendría a corroborar la dificultad de hacer compatible la democracia con las concepciones organicistas del Estado, y la ruptura de la ilusión de una solución corporativa democrática como la defendida por Posada desde el organicismo social de base constitucional (estableciendo una representación política y social en el Estado con un sistema bicameral de representación política y de intereses ${ }^{234}$ ); y lo fue tanto respecto de la pretendida mejora de la representatividad como desde el punto de vista de la eficacia de la acción de gobierno. Era también una forma de intentar superar el mito ideológico de la burguesía conservadora de una estructura "unitaria" y homogénea de la sociedad del capitalismo, lo cual no se correspondía con la realidad, produciéndose en este caso una contradicción inmanente entre ideología (en este caso deformada) y la realidad de los conflictos entre clases antagónicas, cuya superación o atenuación sólo podría producirse a través de transformaciones cualitativas de una realidad, que debería partir precisamente del pleno reconocimiento de su real existencia. La "solución corporativa" partió de esa realidad pero la trató de reconducir

\footnotetext{
${ }^{232}$ POSADA,A.: La crisis del Estado y el Derecho Político, cit., págs.156-157.

${ }^{233}$ POSADA,A.: La crisis del Estado y el Derecho Político, cit., pág.157. Nótese que Posada intenta apoyarse expresamente en su argumentación en KELSEN,H.: La Démocratie. Sa Nature. Su Valeur, París, 1932, págs.26 y sigs. Véase la versión española, Esencia y valor de la democracia, trad.L.Legaz Lacambra y Rafael Luengo, y Est.prel., de J.L.Monereo Pérez, Granada, Comares (Colección Crítica del Derecho), 2002.

La "zona" de peligro se acrecienta cuando reflexiona: "la realización de las "esencias" del Estado, concebido éste como expresión de un orden social políticamente constituido en régimen de garantías de la personalidad humana, no depende, como de condición necesaria, de la persistencia del régimen parlamentario, ni de ninguna forma política determinada: esas esencias -que se sintetizan en la idea, y el goce de la libertad, y en la consideración del hombre como ser libre -fin en si- pueden realizarse bajo este o aquel régimen -el parlamentario u otro-, tan plenamente como lo consientan las circunstancias de cada pueblo, su formación cultural, la elevación de su ideal..., y la disposición del ánimo de las gentes frente a la acción dominadora de quien o de quienes detenten el Poder público". Cfr. POSADA,A.: La crisis del Estado y el Derecho Político, Madrid, C.Bermejo, 1934, pág.162. Aquí aunque trata de proteger la actitud crítica del individuo frente al Estado, late la consideración crítica del régimen parlamentario. La crítica se hace explícita: "los Parlamentos afirma- constituidos como cámaras representativas mediante las aplicaciones mejor o per realizadas del sufragio, no responden fielmente a las exigencias del moderno vivir social, ni pueden reflejar, dada su composición, la compleja naturaleza de las sociedades actuales, ni, por tanto, recoger en su funcionamiento las manifestaciones, las aspiraciones y las necesidades de las formaciones colectivas diferenciadas teleológicamente, y que con los individuos integran el medio dinámico del Estado" (Ibid.,pág.163).

${ }^{234}$ POSADA,A.: La crisis del Estado y el Derecho Político, cit., págs. 165 y sigs., como había defendido antes en su obra La reforma constitucional, cit., págs.108-109.
} 
nuevamente al orden bajo una instauración de un sistema totalitario que agudizaba las desigualdades más que superarlas o reducirlas ${ }^{235}$.

Que su enfoque de la "democracia orgánica" se entiende como compatible con la democracia representativa a través de los partidos políticos, el sufragio universal y libre, se refleja en su idea de Estado social, donde éste adquiere un contenido social ${ }^{236}$. De lo que se trata de instaurar un Estado jurídico y social, el cual "presupone el advenimiento de la vida libre, de la ciudadanía plena de los hombres, y una saturación ética de los elementos sociales organizados y constituidos en núcleos, o en instituciones con función colectiva; presupone, además, una intensificación mínima de la conciencia jurídica en la comunidad, de tal suerte que todos sus factores, individuales y colectivos, alcanzan aquel grado de sensibilidad necesaria para frenar su acción en vista del bien general y según las exigencias de la solidaridad humana; y presupone, por fin la difusión de un mínimum de bienestar económico por toda la comunidad. Sobre esa cimentación se podrá levantar una organización política que asegure al Estado aquella posición neutral, mejor imparcial, que le permita contemplar con serenidad, libre de pasiones, las luchas sociales y de intereses, y constituirse así en órgano supremo de la justicia social, y en fuerza eficaz contra las iniquidades sociales". En Estado social y jurídico nacional (Estado Social de Derecho), pero con orientación supranacional. Posada da cuenta del cambio de paradigma histórico que se opera con el surgimiento del constitucionalismo democrático-social, esto es, un nuevo orden constitucional que garantizar a todos los derechos fundamentales partiendo del derecho a la existencia digna de la persona: "La interpretación misma del proceso histórico, que alcanza un momento culminante con el constitucionalismo, impone como base humana al Estado, la afirmación y defensa jurídicas de los derechos de la personalidad, con su condición esencial

\footnotetext{
${ }^{235}$ La defensa de una solución corporativa era muy generalizada entre finales del siglo diecinueve y el primer tercio del siglo veinte, y sería defendida significativamente desde el solidarismo social integrador de Durkheim. Éste planteó una solución corporativa como la funcionalmente más coherente a la organización moderna de la actividad industrial. La solución corporativa podía contribuir a superar la división del trabajo anómica, y en cuanto tal no productora de solidaridad positiva (solidaridad orgánica). En este sentido, la solución corporativa se vinculaba con la garantía de los derechos de ciudadanía garantizando la efectividad de los derechos en el ámbito de la vida económica y social. En este sentid, MONEREO PÉREZ, J.L.: "Cuestión social y reforma moral: las corporaciones profesionales en Durkheim", estudio preliminar a DURKHEIM, E.: Lecciones de sociología. Física de las costumbres y del Derecho, Granada, Comares, 2006, págs. VII-VIILI, en particular pág. XLIX.

${ }^{236}$ POSADA, A.: Teoría social y jurídica del Estado. El sindicalismo, edición y estudio preliminar, "Sindicalismo reformista integrado y Estado democrático en el republicanismo social de Adolfo Posada" (pp. IX-LXIV.), al cuidado de J.L. Monereo Pérez, Granada, Comares (Col. Crítica del Derecho), 2018, págs. 84 y sigs. observa, por ejemplo, que "la democracia orgánica, con todas sus instituciones populares; sufragio amplísimo, iniciativa popular, referéndum, intervención directa del ciudadano en la gestión de los intereses de la comunidad, cuando es posible, amén de la fuerza creciente de la opinión pública en la marcha de los gobiernos, son otras tantas manifestaciones eficaces de la acción de la tendencia a que aludidos" de transformación social y jurídica del Estado (Ibid., pág. 84.). La democracia implica la libertad en su más amplio sentido y la igualdad no sólo jurídica, sino también material: todas los individuos ha de ser "respetados en su dignidad moral, y reciban en la comunidad las condiciones mínimas de una existencia humana. La esclavitud económica, sea cual fuere su forma, la miseria inicial en la vida, el abandono social del niño, del débil, la desigualdad fundamental que somete el hombre al hombre, el tráfico del trabajo humano, que hace del hombre puro medio, son otras tantas negaciones o violaciones del régimen jurídico de un Estado verdaderamente humano" (Ibid., págs. 90-91).
} 
la libertad: desde la de conciencia, libertad primordial, hasta la de actividad en sus ricas manifestaciones. Frente al hombre libre, la misión del Estado es crear, o hacer posible, un régimen de igualdad de condiciones elementales de vista (porque lo primero es vivir), que permita o produzca una equitativa distribución de goces. La efectividad positiva del derecho de personalidad, en un régimen que no sea el del estado de naturaleza, en un régimen civil o civilizado, exige que el hombre pueda afirmar su propia substantividad física y moral, y ello requiere que el medio social en que el hombre se mueve, sea el adecuado para el desarrollo de una vida humana; tal exigencia genera este capital principio todo individuo debe gozar, por obra del esfuerzo colectivo, una mínimum de condiciones económicas, culturales y jurídicas, que le permitan actuar en la vida social con la capacidad mínima suficiente, para lograr una existencia digna del hombre. Es decir, de un ser que no es un puro medio". A tal efecto recuerda el conjunto de disposiciones relativas al modelo político y socio-económico de la Constitución alemana de 1919. Es sobre esta base constitucional sobre la que se ha de asentar el nuevo Estado social y jurídico, pluralista en lo político y en lo social (Estado Social de Derecho), pues garantiza los derechos y libertades y reconoce los espacios de autonomía y coordinación de los diferentes colectivos y formaciones sociales donde los individuos desarrollan su personalidad (incluidos los sindicatos, núcleos sociales, o formaciones regionales o nacionales, institucionales, etcétera). De ahí que el Estado social y jurídico (Estado Social de Derecho) ha de ser por imperativo constitucional -y no solo éticotiene que ser un Estado activo, intervencionista, no puede tener una actitud pasiva o de abstención, pues debe ser un "órgano de la comunidad misma, órgano vivo, activo", y "sentir como suyas que son, las necesidades de la comunidad". Debe de responder "a los anhelos jurídicos de una vida social digna del hombre"237. Es en esta concepción cómo Posada contempla un sindicalismo reformista y de integración, que en la complejidad de las sociedades humanas expresa un movimiento de diferenciación de los intereses de clase, de los intereses profesionales, que encarnan en agrupaciones homogéneas bajo la atracción irresistible del fin, la defensa del interés, de la profesión, de clase. El sindicalismo refleja con Duguit- la organización de una masa amorfa de individuos; es la constitución en la sociedad de grupos fuertes y coherentes, de estructura jurídica definida, y compuestos de individuos ya unidos por la comunidad de ocupación, de tarea social y de interés profesional o de clase social. De ahí que existan profundos y complejos enlaces del movimiento sindical con el proceso total del desarrollo de las sociedades complejas del presente. En este contexto apuesta por un sindicalismo reformista y no revolucionario como el defendido por G. Sorel junto con el instrumento de presión de la huelga general revolucionaria. Y esa misma lógica muestra sus simpatías hacia el "socialismo gremialista" de laborismo inglés y señaladamente a la concepción mantenida por Cole, que subraya que al lado del Estado está la organización económica realizada democráticamente ${ }^{238}$. Adolfo Posada realza que "el sindicalismo es un

237 POSADA, A.: Teoría social y jurídica del Estado. El sindicalismo, edición y estudio preliminar, "Sindicalismo reformista integrado y Estado democrático en el republicanismo social de Adolfo Posada" (pp. IX-LXIV.), al cuidado de J.L. Monereo Pérez, Granada, Comares (Col. Crítica del Derecho), 2018, págs. 124127.

238 POSADA, A.: Teoría social y jurídica del Estado. El sindicalismo, edición y estudio preliminar, "Sindicalismo reformista integrado y Estado democrático en el republicanismo social de Adolfo Posada" (pp. 
instrumento de democratización social hacia adentro, en o para la realización de su función, y en la ordenación de su estructura; aspira a democratizar la industria, deshaciendo o atenuando las jerarquías que suponen e imponen las prerrogativas del capital". Su concepción de la "democracia orgánica" enlaza con la reflexión de Cole en el sentido de la afirmación de éste en su obra Social theory: La democracia real se encontrará en un sistema pluralista de cuerpos representativos funcionales coordinados. El problema fundamental del Estado, frente a las corrientes diversas del sindicalismo, estriba en hallarles cauces, en elaborar un amplio orden jurídico que facilite su incorporación al régimen políticodemocrático, configurando institucionalmente a las organizaciones profesionales como sujetos sociopolíticos; en definitiva, estriba, en lo principal, en conseguir su propia transformación, en consonancia con las reales y positivas transformaciones que las necesidades nuevas de la vida o las nueva formas de sentirlas imponen o hacen aconsejable a las sociedades contemporáneas ${ }^{239}$.

Pero Posada defiende un republicanismo democrático; su liberalismo social, lejos de oponerse a la democracia es realización de la misma. Por otra parte, el encauzamiento e institucionalización de los intereses hacia el Estado ("las agrupaciones todas deben hablar en el Estado"), se realiza también bajo el criterio de que se reduzca su influjo perturbador sobre el Estado; y, además, de ningún modo se puede admitir que los intereses dominen el Estado, que no es una coalición de intereses, el cual debe estar orientado desde el punto de vista del "interés común -el hombre-, que es el que debe inspirar la acción del Estado, ya que éste debe representar el interés común o general, difícil de definir, sin duda. Debe, por consiguiente, hacerse prevalecer la solidaridad nacional sobre las solidaridades profesionales parciales ${ }^{240}$. Y es que no se puede ignorar que las propuestas sobre la oportunidad de crear un parlamento industrial o profesional se insertan en un intenso debate histórico sobre el papel de los sindicatos en el gobierno de la economía y en el control de las empresas y los límites que imponía el sistema liberal ${ }^{241}$. El régimen liberal doctrinario -y menos todavía el de la Dictadura de Primo de Rivera, cuyo programa y sus realizaciones

IX-LXIV.), al cuidado de J.L. Monereo Pérez, Granada, Comares (Col. Crítica del Derecho), 2018, págs. 132133 y $135-140$.

239 POSADA, A.: Teoría social y jurídica del Estado. El sindicalismo, edición y estudio preliminar, "Sindicalismo reformista integrado y Estado democrático en el republicanismo social de Adolfo Posada" (pp. IX-LXIV.), al cuidado de J.L. Monereo Pérez, Granada, Comares (Col. Crítica del Derecho), 2018, págs. 140142.

${ }^{240}$ POSADA,A.: La reforma constitucional, cit., págs.141-142. Se podría decir, entonces, con Ahrens, que este sistema descansa en el sufragio universal, no abstracto y confuso, sino organizado, determinado según los grandes órganos permanentes de la vida y de la cultura, y se opone, no á la democracia honrada, sino á la demagogia que explota en provecho de los "mangoneadores" (sic) la docilidad, los conocimientos imperfectos y las pasiones del mayor número; él divide e impera en un sentido, justo, libertad no a los electores del imperio de los partidos, constituyéndolos dueños de hacer por sí mismos la elección según su propia inteligencia. Cfr. AHRENS,E.: Curso de Derecho Natural ó de Filosofía del Derecho, cit., pág.612. Habría que matizar de inmediato, que Posada nunca pensó, como propuesta actual, en la supresión del sistema de partidos, manteniendo su compromiso con la la democracia de partidos.

${ }^{241}$ Cuestión que quedaba más evidenciada si cabe en el debate constitucional de la República de Weimar. Véase KIRCHHEIMER,O.: Costituzione senza sovrano. Saggi di teoria politica e costituzionale, a cargo de A.Bolaffi, Bari, 1982; BOLAFFI,A.: Il crepuscolo della sovranità. Filosofia e politica nella Germania del Novecento, Donzelli Editore, 2002. 
quedarían agotadas al fin de la década de los veinte- no podía articular una respuesta adecuada a las pretensiones de participación e influencia de las organizaciones sindicales en la esfera de la política económica y de la influencia en las decisiones de gestión de las empresas. El reformismo no supo -y también encontró dificultades en el seno de la patronalpara imponer su estrategia liberal reformista para atemperar la constitución socio-económica de base liberal individualista. La racionalización democrático-social de la eufemísticamente llamada "cuestión social" fue un tema pendiente que quedaba abierta con la apertura hacia la instauración de la II República y su constitucionalismo social.

Con todo, Posada deja muy claro que su "democracia orgánica" es plenamente respetuosa con la democracia representativa parlamentaria de corte liberal: La organización constitucional -afirma- más aceptable en las democracias modernas será, sin duda, aquella mediante la cual se logre hacer efectiva la armonía de todos los intereses, de modo que predomine la preocupación del interés nacional o general. La democracia no puede ignorar la existencia de los intereses diferenciados en el seno de la vida nacional; pero no puede permitir que el interés supremo de la comunidad resulte sometido a ningún interés diferenciado, ni puede estimar que los intereses diferenciados especializados sean los que definan el interés general. Por tanto, y de modo inequívoco, es preciso decir que la determinación del interés general es función de la representación del país, que debe condensarse en el Cuerpo electoral -político por esencia-, y de donde ha de surgir,_como su fuente, la Cámara popular ${ }^{242}$. Destáquese la posición de Posada respecto al mantenimiento de las estructuras parlamentarias de representación política general y el carácter simplemente complementario e integrador de una posible Cámara profesional ${ }^{243}$. En el plano de la

\footnotetext{
${ }^{242}$ POSADA,A.: La reforma constitucional, cit., págs.142-143.

${ }^{243}$ Ahrens había matizado que sin duda esta sistema de elección por grupos de intereses sociales ("o por estados"), si se adoptara solamente para una de las dos Cámaras, podría ser un correctivo bastante poderoso para (el) sistema ordinario, y preparar el espíritu público a ver en la misma sociedad un organismo de diversos órdenes ó grupos de hombres y de intereses, pero no puede ser considerado como el sistema verdadero y completo, porque para Ahrens (que en su en su doctrina orgánica del Estado de 1850 había defendido una combinación entre el sistema de elección por intereses para la primera Cámara con el sistema ordinario localizado para la segunda Cámara) el sistema natural de elección y de representación debe ser un reflejo y en cierto modo un extracto del organismo social. Este se compone de dos especies de grupos o de esferas: por un lado, de esferas que, comprendiendo á todos los hombres bajo todos los aspectos principales de la vida, bajo los diversos grados de familia, del municipio, de provincia, mantienen la unidad y la totalidad de la personalidad individual y colectiva, y por otro lado, de esferas de cultura constituidas por la división natural del trabajo social según los fines principales de la vida humana. Sobre el tipo de este organismo se establece un sistema de elección tan sencillo como natural.. Con arreglo a ello, la representación general ó nacional, para reflejar este organismo interno de la sociedad en sus dos géneros de grupos, deberá ser producto de un doble sistema de elección, y dividirse en dos Asambleas o Cámaras, descansando sobre distintos principios, de los cuales, uno, al que llamaremos primero, representaría las esferas de la vida completa o los grandes centros de vida localizados en diversos grados, y constituidos en último lugar por las provincias de un Estado más unitario o por Estados miembros de un Estado federativo. La segunda Cámara, al contrario, se formaría por elección en los diversos órdenes de cultura ó, como se dice, de intereses sociales. Semejante sistema de elección y de representación presentaría grandes ventajas. Hace notar, por lo demás, que este sistema no existe ya en estado de simple teoría, puede tener su apoyo en experimentos en parte muy felices y casi decisivos. Porque la organización de la primera Cámara se funda sobre el mismo principio que ha guiado para la excelente constitución del Senado en los Estados-Unidos, y desde 1848 ha sido aplicada en Holanda para la elección de la primera Cámara por los Estados provinciales. Cfr. AHRENS,E.: Curso de Derecho Natural ó de Filosofía del Derecho, cit.,págs.609 a 614.
} 
reforma constitucional, las Cortes debería estructurarse en dos Cámaras: Congreso de los Diputados, la una, la "popular", y Senado ${ }^{244}$, la otra, la representación de los intereses sociales organizados. Pero ambos no se encuentran en posición simétrica, porque dados los supuestos formulados en relación con las exigencias de una organización constitucional de la democracia, las Cámaras de las Cortes futuras no podrían ser "iguales en facultades"245. Su posición está jerárquicamente establecida: La dos Cámaras deberían ejercer la función legislativa del Estado, pero en caso de conflicto por discrepancia entre ambas, con tramitación adecuada que serviría de garantía a los intereses, tendría que prevalecer lo sostenido por la Cámara popular, representativa del interés general. Correspondería al Congreso definir la política del Gobierno ${ }^{246}$. Esta idea de una representación política y social en el Estado se reiterará en años después, especialmente en la fecha emblemática de $1934^{247}$, donde vuelve a "lamentar que las Constituyentes españolas de la segunda República, no hayan querido considerar la realidad nacional sobre la que debía asentarse el Estado oficial del nuevo régimen". Y añade: "No se dieron cuenta los constituyentes del momento en que actuaban, tan lejano históricamente de 1789, tan impropio para expansiones de jacobinos, y tan oportuno, en cambio, para intentar introducir en la Constitución política la representación específica de los intereses sociales organizados, creando al lado de la Cámara popular, representativa del conjunto numérico y de asiento geográfico de los ciudadanos, una Cámara sindical representativa de aquellos intereses, Cámara que ya echan de menos algunas gentes, incluso los que impidieron que la Constitución de 1931 fuera hoy argumento vivo que oponer a la crítica fascista"248. Para Posada las estructuras corporativistas en democracia permitiría reconducir los conflictos sociales y la proliferación de organizaciones de intereses colectivos o sectoriales hacia la esfera política institucional por contraposición a las tendencias disgregadoras y atomistas que propiciaron los sistemas liberales individualistas.

Con cierta ingenuidad -y error en el análisis- sobreestima la importancia de la introducción de dicha cámara profesional como antídoto frente a los regímenes fascistas: Cámara que ya echan de menos algunas gentes, incluso de las que impidieron que la Constitución de 1931 fuera hoy argumento vivo que oponer a una crítica fascista. El ambiente hoy tan favorable al llamado régimen corporativo, más político que social en el fascismo, pudiera, en parte,

\footnotetext{
${ }^{244}$ Nótese la vinculación, harto significativa de cierta confluencia de propósitos, con AHRENS,E.: Curso de Derecho Natural ó de Filosofía del Derecho, cit.,págs. 609 a 614.

${ }^{245}$ Precisamente a causa de su composición y de su distinta significación social deberían tener intervención política y participación en la función legislativa de diverso carácter y con distinto alcance. La representación política de la Nación corresponde, sin duda, al Congreso de los Diputados elegidos directamente por el Cuerpo electoral de la Nación, de amplia base, y órgano (de la democracia) más inmediato de la soberanía y del interés general. Las instituciones, corporaciones y agrupaciones socialmente constituidas, deben tener su representación más propia en el Senado -en donde podrán manifestarse y ser oídos los intereses locales y sociales de toda índole, y muy especialmente, con representación muy amplia, los de carácter cultural y los de carácter económico. Cfr.POSADA,A.: La reforma constitucional, cit.,págs.144-145. Posada concebía una cámara corporativa de composición compleja ya estaría integrada por representaciones de intereses tanto "locales" como "sociales" de toda índole. Esto plantearía muchos problemas de articulación y organización de su funcionamiento.

${ }^{246}$ POSADA,A.: La reforma constitucional, cit., págs.144-145.

${ }^{247}$ POSADA,A.: La crisis del Estado y el Derecho Político, Madrid, C.Bermejo editor, 1934, págs.165 y sigs. ${ }^{248}$ POSADA,A.: La crisis del Estado y el Derecho Político, cit., pág. 166.
} 
explicarse como reacción contra el insistente abandono del punto de vista social en el régimen liberal y parlamentario y contra el hecho de que las Asambleas representativas, Parlamentos o no. Las Asambleas representativas y sus aledaños, constituyen el campo en el cual maniobran los intereses particulares y del cual tan frecuentemente éstos se adueñan, empleando sus inagotables medios corruptores y hasta gangrenosos de persuasión. Lo honesto sería que esos intereses actuaran constitucionalmente, pero en su Cámara y mediante sus legítimos representantes ${ }^{249}$. Ni esta era la solución; ni este era el problema, en una coyuntura dominada por el miedo recíproco y la lucha abierta entre fuerzas políticas y sociales que presionaban contradictoriamente por la instauración de un orden diverso al existente. El problema, pues, no residía en el sistema de representación de los intereses sociales en el Estado sino el de la conformación del sistema político mismo al servicio de los modelos proponibles y defendibles de organización del sistema social en su conjunto. Tampoco residía en la anhelada armonía entre la Democracia y la eficiencia desde el punto de vista político, lo que exigiría -según Posada- la instauración de un régimen que hiciera compatible la existencia del Parlamento, institución de la democracia y representativa de la política "por y para el Pueblo", con la ordenación de las fuerzas sociales constituidas por los intereses de tipo colectivo y organizados en grupos: asociaciones, sindicatos ${ }^{250}$. El problema de la eficacia no derivaba, en realidad tanto de razones internas como de factores externos de causación; entre ellas la falta de respecto a las mismas reglas de juego del sistema democrático de la República y la tentación constante del recurso a las vías de hecho en respuesta a un Gobierno legítimo de la Nación. Frente a lo que pensaba Posada, la creación de un cámara profesional no parece que tuviera la virtualidad por él atribuida de a la larga hacer innecesaria la aplicación de la luchas de clases, como método político de transformación social, hasta por vía cruenta. El coronamiento -incluso estético- de esta organización social sería una Cámara o Senado en una buena parte de base sindical, representativa de los intereses sociales organizados, y que no actuaría como Consejo de funciones consultivas o de asesoramiento técnicos del Legislativo. Tal Cámara no sería, en rigor, técnica, sino representativa de la Política de los intereses. La Cámara habría de ser un Cuerpo Colegislador de carácter permanente, es decir, no sometido, como la Cámara popular, órgano de opinión, a la prerrogativa de disolución del jefe del Estado, por lo que, en caso de conflicto en la labor legislativa entre las dos Cámaras, la de los "intereses" debería ceder a las decisiones reiteradas de la "popular" ${ }^{251}$.

Lo propuesto es un sistema de doble representación, perseguido con el establecimiento del doble sufragio individual y social (a saber: la política del Parlamento, proveniente del sufragio, órgano específico de opinión pública, y la social y económica, de Consejos o Senados, de base sindical o corporativa ${ }^{252}$ que se estima en consonancia con la complejidad de la realidad social. El proceso se completaría con la creación de organicismo, como el

\footnotetext{
${ }^{249}$ POSADA,A.: La crisis del Estado y el Derecho Político, cit., pág.166.

${ }^{250}$ POSADA,A.: La crisis del Estado y el Derecho Político, cit., pág.167.

${ }^{251}$ POSADA,A.: La crisis del Estado y el Derecho Político, cit., págs.167-168.

${ }^{252}$ Posada se apoya aquí en la obra de LAVERGNE,V.: Le Gouvernement des Démocraties Modernes. La nécessité du double suffrage universel-suffrage individuel et suffrage social, París, 1933.
} 
Consejo Nacional Económico, que armonicen todos los intereses legítimos de las diversas ramas de la economía ${ }^{253}$. Dentro de ese margen de relativa contradicción interna que puede apreciarse en Posada el compromiso con la democracia frente a la dictadura: debe afirmarse que la solución no puede implicar por necesidad el entronizar un régimen dictatorial que se traduciría en la negación del carácter representativo de la Asamblea legislativa, organizada entonces --si se mantiene- sobre la base de la supresión de la libertad política y del imperio del querer exclusivo de un partido, llámese "bolchevista" (bolchevique), fascista o hitleriano. Eso es lo que precisamente se quiere impedir al "reformar" el régimen de Parlamentos ${ }^{254}$. Esta era la que bien podría llamarse utopía corporativista de Adolfo Posada.

Una de las soluciones generales del problema de la organización política del sufragio es para Posada la introducción aditiva de la representación corporativa y de los intereses. Su idea no es la de atenuar los efectos niveladores del sufragio, sino más bien para adaptarlo a la verdadera naturaleza del Estado, que no es nuca una suma de individuos, o bien, para hacer de él un instrumento vivo y consciente, un verdadero órgano, que nutra de toda la savia social y resuma y compendie todo cuanto en la sociedad existe. En el Estado no hay sólo individuos, sino intereses, corporaciones, elementos sociales, en suma, que debe reflejarse mediante un sufragio propio, en la representación política ${ }^{255}$. Propone la organización del sufragio por la representación de los intereses. El punto de partida de esa propuesta es que ante el aspecto inorgánico que a primera vista ofrece el sufragio, sobre todo el llamado universal, cuando se consagra prácticamente, por la fuerza misma de las cosas, como la base capital de la vida política, se ha tendido por algunos a procurarle cierta organización y una fuerza menos violenta y más reflexiva y social, mediante una conveniente y calculada distribución de la función electoral por los grupos que en la sociedad existen, en virtud de la acción del espíritu corporativo de clase o del interés que atrae a los individuos, obligándoles a formar esos grupos o colectividades más o menos permanentes ${ }^{256}$.

Por otra parte, el sufragio meramente individual, además de no responder a la naturaleza del Estado, no puede producir una opinión meditada ni homogénea. No puede ser meditada, por el carácter mismo de universalidad que tiene, y porque aparece constituido por una masa demasiado enorme, para ser reflexiva; y no puede ser homogénea, por lo heterogéneo de su composición $^{257}$. Es el sufragio orgánico por la representación de los intereses. Sin embargo criticará la tendencia sustitutiva de esta forma de representación: entraña -afirma-, es verdad, la solución, de un lado ciertas limitaciones que no es posible aceptar, en cuanto parece olvidarse la importancia del hombre como ser político e independientemente de su calidad particular como tal o cual cosas (abogado, obrero, agricultor, etc.); y además, una organización del sufragio por agrupaciones de intereses, implicaría el peligro de disolver la unidad del Estado, que se funda en la naturaleza humana, convirtiéndola en una unidad por superposición de clases y asociaciones, y el no menos grave de crear los partidos de clase y

\footnotetext{
${ }^{253}$ POSADA,A.: La crisis del Estado y el Derecho Político, cit.,págs.178-179.

${ }^{254}$ POSADA,A.: La crisis del Estado y el Derecho Político, cit., pág.169.

${ }^{255}$ POSADA,A.: El sufragio, cit., cap.XXII, págs. 135 y 152 y sigs.

${ }^{256}$ POSADA,A.: El sufragio, cit., pág. 152.

${ }^{257}$ POSADA,A.: El sufragio, cit., pág. 153.
} 
de interés de clase, con el espíritu de clases por guía, convirtiendo la vida política en mera lucha utilitaria de intereses; pero no obstante esto, es necesario reconocer que, en efecto, en la sociedad no hay sólo individuos, y que es preciso que de alguna manera se advierta en su vida, la acción del otro elemento que al lado del individual existe en la sociedad política, a saber: del elemento social. Por ello considera que la doctrina de la representación de los intereses debe ser rectificada y completada con la concepción orgánica del Estado, la cual ve en éste, no una suma de individuos, sino un conjunto de personas individuales y colectivas, considerando, en consecuencia, que no puede estimarse la voluntad del Estado como la simple suma de las voluntades del cuerpo electoral, por amplio que éste se conciba $^{258}$. Giner había señalado que dondequiera que existe un orden jurídico, allí nace un Estado, ora se trate de un individuo, ora de una comunidad. O, para hablar más propiamente, toda personalidad de Derecho, así individual como social, constituye un Estado, en cuanto convierte toda su actividad a cumplir sus obligaciones interiores jurídicas. Por otra parte, el fin del Estado es cumplir el Derecho. Es pues evidente que debe concebirse el Estado, no como el orden jurídico ni el poder (concepciones entitativas y abstractas), ni siquiera como el ser jurídico en todo el sentido de la palabra; sino como la persona (no todo ser jurídico es persona, ni lo ha menester jamás en tanto que no se trata de sujeto obligado) en su función de presentarse a sí misma y, en caso de ser social, a sus miembros (interiormente) las condiciones jurídicas de su vida. En las relaciones (exteriores) de cada persona con los demás, no es Estado, sino miembro del Estado superior común, de que con ellas forma parte $^{259}$.

Desde la filosofía krausista, que Posada acoge, insiste en el carácter compuesto, verdaderamente orgánico, es decir, vivo y complejo, de la sociedad y del Estado, en los cuales hay de un lado individuos, seres políticos, ciudadanos, cuya acción en el Estado es evidente, y de otro, corporaciones, entidades, colectividades, constituidas para reflejar de una manera más intensiva y complicada, los distintos fines de la vida ${ }^{260}$. Piensa que debe organizarse el sufragio de modo que refleje toda la vida social, de manera que quede constancia institucional de que la opinión pública de un Estado no tiene como órganos de expresión, tan sólo a los individuos, sino también a las Corporaciones que se forman por la comunidad de fines y de intereses en razón de cualquier manifestación del espíritu de solidaridad. Con base a ello, si se reconoce el sufragio -derecho y poder políticos- en los ciudadanos aptos para ello, debe reconocerse ese mismo sufragio, a las Corporaciones sociales, que se reputen aptas para ejercer semejante función cívica. Lo importante es realzar que para Posada no existe una incompatibilidad de principio entre esas dos formas del sufragio político. En coherencia con ello, no deben jamás organizarse como dos formas enemigas, es decir, con el ánimo de oponer la una a la otra, lo cual se conseguirá, quizá,

\footnotetext{
${ }^{258}$ POSADA,A.: El sufragio, cit., pág.153. Ahrens había mantenido, por su parte, una concepción éticoorgánica del Estado. Cfr. AHRENS,E.: Curso de Derecho Natural ó de Filosofía del Derecho, cit., págs.568 a 570, y passim.

${ }^{259}$ GINER DE LOS RÍOS,F.: Vida y obras de Enrique Ahrens, en GINER DE LOS RÍOS,F.y AZCÁRACTE,G.: Notas a la Enciclopedia jurídica de Ahrens, con una nota sobre Arrendamientos rurales y pecuarios de Joaquín Costa, y Prólogo de Pablo de Azcárate, Madrid, Tecnos, 1965, págs.106-107.

${ }^{260}$ POSADA,A.: El sufragio, cit., págs.154-155.
} 
otorgando la representación corporativa a todos los intereses de carácter social, que tengan fuerza suficiente para provocar instituciones propias permanentes y vigorosas (sociedades cooperativas $^{261}$, universidades, cámaras agrícolas, sociedades obreras, asociaciones privadas de enseñanza, gremios, municipios, etc. $)^{262}$.

En el marco de la defensa de una "democracia orgánica", Posada quiere dar entrada en el sistema democrático a las organizaciones de intereses (al "hombre colectivo"), como complemento de la cámara que representa directamente la voluntad general. A pesar de su organicismo no pretendía negar el conflicto, sino institucionalizarlo y reconducirlo hacia cauces de solución pacífica. Ello le alejaba de toda proximidad con las propuestas del corporativismo fascista. Es su alternativa organicista a los regímenes totalitarios, consistente en establecer un Estado corporativo democrático que conserve las instituciones esenciales de la democracia liberal. Pero Posada no proponía una reforma de las estructuras económicas y sociales que pudieran acaso intentar vertebrar la cámara corporativa con un proyecto de democratización de todo el sistema económico e industrial ${ }^{263}$. Esa alternativa, más allá de su realismo práctico y de sus riesgos evidentes, se realizaba explícitamente como mecanismo reformador para consolidar el régimen democrático, en una época trágica de crisis del Estado y del capitalismo. Una democracia orgánica y jerarquizada, que para él supone un democracia elitista, porque, a su entender, la democracia no tiene porqué ser niveladora, de forma gregaria y de espíritu igualitario ${ }^{264}$. En el pensamiento de Posada, la misma representación política es una relación propiamente orgánica. Se ha advertido, que en él el Estado está naturalmente representado de manera continua por todos y cada uno de sus ciudadanos, con independencia de que esta relación esté consagrada o no jurídicamente. La relación representativa se identifica con la puramente orgánica y la perspectiva jurídica con la sociológica ${ }^{265}$.

No trata de oponer la representación de intereses a la representación política. Posada defiende la extensión del sufragio y la transparencia electoral ${ }^{266}$. La defensa del sufragio universal no es sustituida por la propuesta complementaria de un sufragio corporativo. La visión del sufragio en Posada se relaciona con la idea de que el elemento esencial de la vida política democrática es el individuo en sî́27. Para Posada el sufragio más que un derecho es

\footnotetext{
${ }^{261}$ Véase PIERNAS HURTADO,J.M.: El movimiento cooperativo. Tres conferencias dadas en el Fomento de las Artes, Madrid, 1890. Una de las leyes sociales más necesarias en el marco del proyectado Instituto del Trabajo era precisamente el fomento de la formación de cooperativas obreras de todas clases. Cfr. CANALEJAS,J.: "Discurso preliminar" a BUYLLA,A.,POSADA,A.,y MOROTE,L.: El Instituto del Trabajo(1902), cit., pág. 12.

${ }^{262}$ Cfr. POSADA,A.: El sufragio, cit., págs.155-156.

${ }^{263}$ Esa era la propuesta desde distintas corrientes del socialismo democrático, como el socialismo gremial inglés y la propuesta de socialización y democratización del sistema económico en Alemania y Austria.

${ }^{264}$ En este sentido POSADA,A.: La reforma constitucional, cit., pág.134.; POSADA,A.: La crisis del Estado, cit., págs.147 sigs.

${ }^{265}$ RUBIO LLORENTE,F.: "Estudio preliminar" a la obra de POSADA,A.: Estudios sobre el Régimen Parlamentario en España, Oviedo, Junta General del Principado de Asturias, 1996, págs. LXXIII-LXXIV.

${ }^{266}$ POSADA,A.: El sufragio, Barcelona, Manuales Soler, s/f.

${ }^{267}$ POSADA,A.: Régimen constitucional, cit., pág.56.
} 
una función, siendo así que el cuerpo electoral aparece como órgano del Estado ${ }^{268}$. Considera positiva la evolución hacia el sufragio universal y propuso esa solución en sus "Bases para la Constitución política de España"269. Desde la familia del krausismo se había visto en la extensión del sufragio universal una forma de pacíficación y facilitación de la colaboración entre las clases, frente al planteamiento rupturista que planteaba la existencia del "partido obrero" y de clase; a través de él el "cuarto estado" podría exigir las reformas pertinentes de mejora de su situación a través de procedimientos legales y pacíficos ${ }^{270}$. Sin embargo, en el enfoque evolucionado del krausoinstitucionalismo -y señaladamente en Adolfo Posada- se produce un cambio hacia la exigencia de una intervención permanente del Estado tutela, frente a la consideración anterior que afirmaba el carácter transitorio de dicha intervención de tutela ${ }^{271}$. En Posada se superar esa cierta reticencia inicial del liberalismo originario de inspiración krausista hacia convertir el Estado tutelar o intervencionista en fin permanente y esencial del Estado. Hasta tal punto es así que llega afirmar que la cuestión social es, ante todo, una cuestión jurídica y política, buscando en gran medida la solución en el Derecho y encomendándola al Estado. Sucede que la solución del problema social exige del esfuerzo de todos: medidas de carácter "interior" (de transformación del hombre mismo) y medidas de carácter "exterior" que deben ser adoptadas por el Estado. Con todo, el medio principal de alcanzar reformas serias y durables será siempre el propagar principios justos; inspirar convicciones morales más profundas; reanimar también, con relación a la propiedad, el sentimiento de los deberes que todos tienen que cumplir: deberes individuales de moderación y de templanza en el uso de los bienes; deberes sociales de beneficencia, de ayuda, de socorro de los ricos para con los pobres; en fin, deberes de probidad, de lealtad y de justicia en todas las asociaciones, que tienen por objeto la producción, la adquisición y el cambio de los bienes (Ahrens, Filosofía del

\footnotetext{
${ }^{268}$ POSADA,A.: Tratado de Derecho político, t.II, cit.,pág.307; Ibid., La reforma constitucional, cit., pág.137, donde precisa que como representación específica de la comunidad, el sufragio es función a la vez que derecho y deber de carácter cívico. En el mismo sentido se había señalado que "el sufragio es, ciertamente, una función y no un derecho, y por lo mismo pide capacidad; pero ¿por dónde se ha de atribuir ésta al que tiene riqueza, y sólo por tenerla?". Cfr. AZCÁRATE,G.DE.: Resumen de un debate sobre el problema social, Madrid, Gras y Compañía, Editores, 1881, pág.128.

${ }^{269}$ Se incluye como "Apéndice" a su obra POSADA,A.: La reforma constitucional, cit., págs.94 y sigs.

${ }^{270}$ El sufragio universal -decía Azcárate a finales del siglo XIX- "puede contribuir á operar la fusión de las clases, en vez de la separación que mantiene el censo y el partido obrero; él facilitaría al cuarto estado el medio legal y pacífico de hacer oír sus quejas y de formular sus aspiraciones; él haría posible que los partidos políticos se constituyesen para servir á las ideas y a los principios, y no a los egoístas intereses de clase. Y no hay que exagerar los peligros que envuelve; pues si algunos de ellos serían reales si se tratar de un régimen basado en la democracia directa, dejan de serlo en el sistema representativo, pues con sufragio universal, como ha dicho un escritor conservador, reina la armonía, y no el antagonismo, allí donde las clases directoras saben cumplir con su deber". Cfr. AZCÁRATE,G.DE.: Resumen de un debate sobre el problema social, Madrid, Gras y Compañía, Editores, 1881, pág.129.

${ }^{271}$ Azcárate, que luego cambiaría su posición también al respecto, señalaba a finales del siglo diecinueve que: "Pero aunque el Estado, considerado en la esfera puramente ideal, tenga por fin único y esencial la realización del derecho, hallamos que, por razones transitorias, viene influyendo é interviniendo en otros órdenes de la actividad además de aquél. Es debido esto a una institución que juega un importantísimo papel en la historia, pero de la que se ha abusado como de ninguna otra: la tutela". Cfr. AZCÁRATE,G.DE.: Resumen de un debate sobre el problema social, Madrid, Gras y Compañía, Editores, 1881, pág.135.
} 
Derecho $)^{272}$. Ello en el marco de una orientación evolucionista que cree firmemente en la razones civilizatorias de insertas en la lógica del desarrollo y del progreso de la humanidad ("ley del desarrollo progresivo" hacia el "ideal de la humanidad") ${ }^{273}$.

Posada propuso el establecimiento de una representación social y económica, de Consejos o Senados, de base sindical o corporativa. Pero, además, esta representación de intereses estaría en última instancia subordinada a la representación política general ${ }^{274}$. Posada propone una reforma corporativa del Senado manteniendo intacta la representación política general del Parlamento. A través de esta Cámara profesional sería posible encauzar institucionalmente los conflictos de intereses a fin de armonizarlos mediante la reconducción de los intereses particulares hacia el interés general ${ }^{275}$. Esta concepción corporativa se aparta del corporativismo totalitario, ya que nunca se presentó en Posada como una alternativa a la representación política, sino como un complemento con la finalidad explícita de facilitar institucionalmente la solución pacífica de la "cuestión social" devenida en problema propiamente político ${ }^{276}$. La propuesta de Posada -como la de Julián de Besteiro- de constituir una cámara de representación específica de los intereses sociales organizados (Cámara sindical o social), al lado de la Cámara popular, no encontró acogida en el proyecto de Constitución de $1931^{277}$. Tampoco encontró acogida la propuesta de los "Consejos técnicos" realizada por Fernando de los Ríos ${ }^{278}$, que -a pesar de posibles derivaciones tecnocráticasen el fondo pretendía afrontar el problema la compatibilidad entre la democracia y la eficiencia de un Estado de servicio público. Basta reparar en el hecho de que el propio De los Ríos afirmaba la oportunidad de establecer mecanismos de representación específica de intereses sociales organizados ${ }^{279}$.

\footnotetext{
${ }^{272}$ Cfr. AZCÁRATE,G.DE.: Resumen de un debate sobre el problema social, cit., págs.213-214. AHRENS, H.: Curso de Derecho natural ó filosofía del Derecho (1870), Madrid, Carlos Bayllu-Bailliere, 1889.

${ }^{273}$ Véase AZCÁRATE,G.DE.: Resumen de un debate sobre el problema social, cit., Apéndice segundo ("El problema social de ayer y el de hoy"), págs.215 y sigs.

${ }^{274}$ En este sentido POSADA,A.: La reforma constitucional, cit., pág.145.

${ }^{275}$ POSADA,A.: La reforma constitucional, cit.,págs. 138 y sigs.

${ }^{276}$ POSADA,A.: La crisis del Estado y el Derecho político, cit., pág.166; POSADA, A.: España en crisis. La política, cit., págs. 150 y sigs.

${ }^{277}$ De ello se quejaba amargamente POSADA, A.: La crisis del Estado y el Derecho político, cit., pág.166.

${ }^{278} \mathrm{El}$ propio Posada pensaba críticamente que esa propuesta de tecnificación de la política podía derivar en pura tecnocracia. Así lo afirmaba en POSADA,A.: La Nouvelle Constitution espagnole, cit., pág.180. Para él "se olvida que no hay nada más perturbador que una política de técnicos, y que, en todo caso, en la Administración del Estado, la técnica y los técnicos deben estar prudentemente al servicio de la política y de los políticos, teniendo sin duda una influencia sobre la política, pero sin la posibilidad de servir de freno o de condición indispensable para que funcione el órgano que se cree -lo sea o no- representativo de la soberanía" (Ibid.,pág.180).

${ }^{279}$ Véase al respecto MONEREO PÉREZ,J.L.: "El pensamiento jurídico-social de Fernando de los Ríos y su generación", Ponencia presentada al Congreso Fernando de los Ríos y su tiempo, G. Cámara Villar (Coord.), Granada, Servicio de Publicaciones de la Universidad de Granda, 1999. La semblanza que hace Adolfo Posada de Fernando de los Ríos muestra una gran proximidad con el socialismo liberal de aquél. Muchas veces, conversando con Fernando de los Ríos en momentos inolvidables he pensado que hay una manera liberal, de intenso liberalismo, de ser socialista, de sentir los anhelos humanos que han engendrado y mantienen la actitud socialista en el mundo: basta inyectar en las fórmulas del socialismo puro la emoción humanista y completar su acción de protesta contra la injusticia social con el profundo sentido de generosidad característico, por ejemplo, del liberalismo wilsoniano. Cfr. POSADA,A.: Actitud ética ante la guerra y la paz, Madrid, Caro
} 
Posada en su calidad de miembro de la Comisión Jurídica Asesora propuso incluir -como defendía en su libro La reforma constitucional- una representación de intereses complementaria de la representación política general. Pero su propuesta fue desatendida. La inspiración de crear una sola cámara parlamentaria de representación estrictamente política basada en el sistema de partidos reflejaba la influencia de Constituciones democráticosociales contemporáneas como la Constitución de la República de Weimar y la Constitución de la República Austríaca.

\section{5.- Obras de Adolfo González Posada, su pensamiento y época}

\subsection{Obras de Adolfo González Posada (Selección Instrumental)}

POSADA, A.: Fragmentos de mis Memorias, Oviedo, Universidad de Oviedo, Cátedra Aledo, 1983.

POSADA, A.: La crisis del Estado y el Derecho Político, Madrid, C.Bermejo, Impresor, 1934.

POSADA, A.: Tratado de Derecho Político (la última edición es de 1935. Existe una reciente edición especial íntegra en un solo volumen, Editorial Comares (Col. Crítica del Derecho), Granada, 2003.

POSADA, A.: Tratado de Derecho Política, edición crítica íntegra en un solo volumen, y estudio preliminar, "El pensamiento político-jurídico de Adolfo Posada" (pp. VII a CLXIII.), a cargo de J.L. Monereo Pérez, Granada, Comares (Col. Crítica del Derecho), 2003. Es su obra más importante.

POSADA, A.: Principios de sociología, Madrid, Daniel Jorro; $1^{\mathrm{a}}$ ed, 1908; $2^{\mathrm{a}}$ ed. de 1929. Adolfo Posada fue uno de los grandes fundadores de la sociología en España.

POSADA,A.: "Política social y legislación del trabajo", en POSADA, A., CLEMENTE DE DIEGO, F., SELA, A., BERNARDO DE QUIRÓS, C., y SANGRO DE ROS OLANO, P.: Derecho usual, Madrid, Ediciones de la Lectura, s/f., págs.489 y sigs.

POSADA, A.: Estudio preliminar sobre las ideas jurídicas y el método realista de Ihering, IHERING, R.V.: Prehistoria de los indoeuropeos, Madrid, Libr.Gral. de Victoriano Suárez, 1896.

POSADA, A.: Tratado de Derecho Administrativo según las teorías filosóficas y la legislación positiva, $2^{\mathrm{a}}$ ed., revisada, Madrid, Librería General de Victoriano Suárez, 1923.

POSADA, A.: Relaciones científicas con América (Argentina, Chile, Paraguay y Uruguay), Anales de la Junta para la Ampliación de Estudios e Investigaciones científicas, Tomo III, Memoria, $5^{\mathrm{a}}$, s.f. (1910). 88 páginas.

Raggio, 1923, págs.216-217. Véase, igualmente, POSADA, A.: Woodrow Wilson y su obra El Estado, Madrid, Librería General de Victoriano Suárez, 1921. 
POSADA, A.: Les Fonctions Sociales de l' État, París,M.Girad, 1929.

POSADA, A.: El régimen constitucional, Madrid, Librería Gral. de Victoriano Suárez, 1930.

POSADA, A: La reforma constitucional (Madrid, Librería Gral. de Victoriano Suárez, 1931);

POSADA, A.: La nueva orientación del Derecho político, en el libro de DUGUIT, L., La transformación del Estado, Madrid, Librería de Fernando Fe, 1909 (Título originario en francés del libro de Duguit: DUGUIT, L.: Le droit social, le droit individuel et la transformation l'État. París, Felix Alcan, 1908).

POSADA, A.: Hacia un nuevo Derecho político, Madrid, Ed.Páez, 1931.

POSADA, A.: Estudios sobre el régimen parlamentario en España, Madrid, 1891.

POSADA, A.: La ciudad moderna, Madrid, Imprenta Clásica Española, 1915.

POSADA, A.: El régimen municipal en la ciudad moderna, Madrid, Lib.Gral. de Victoriano Suárez, 1916.

POSADA, A.: "El Derecho y la cuestión social", Estudio preliminar a A.MENGER, El derecho civil y los pobres, trad. de A.Posada, Madrid, Librería General de Victoriano Suárez, 1898. Publicado en edición crítica por la Editorial Comares (Col. Crítica del Derecho), Granada, 1998, con Estudio preliminar, "Socialismo jurídico y reforma social: Anton Menger y el socialismo jurídico en España (pp. 7-112)”, de J.L.Monereo Pérez).

POSADA, A.: Socialismo y reforma social, Madrid, Librería Fernando Fe, 1904.

POSADA, A.: Política y Enseñanza (Madrid, Ed.Daniel Jorro, 1904).

POSADA, A.: "Política social y legislación del trabajo", en Derecho usual, Madrid, La Lectura, s/f.

POSADA, A.: Le reforme sociale en Espagne, París, 1907.

POSADA, A.: El sufragio, Barcelona, Sucesores de Manuel Soler-Editores, s/f.

POSADA, A.: Evolución legislativa del régimen local en España, Madrid, Librería General de Victoriano Suárez, 1910.

POSADA, A.: "La nueva orientación del derecho político", Estudio preliminar a DUGUIT,L.: La transformación del Estado, Madrid : Librería de Fernando Fé , [1910?]. Libro recogido en DUGUIT, L.: Las transformaciones del Derecho público y privado, edición crítica de tres monografías de Leon Duguit vinculadas por la idea-fuerza de las transformaciones del Derecho Público y Privado y el por entonces emergente (en estado naciente) Derecho Social, con estudio preliminar, “'Objetivismo jurídico' y teoría de los "derechos" en León Duguit" (pp. XI-XXXIX), a cargo de J.L. Monereo Pérez y J. Calvo González, Granada, Comares (Col. Crítica del Derecho), 2007.

POSADA, A.: El régimen municipal de la Ciudad Moderna y bosquejo del régimen local 
en España, Francia, Inglaterra, Estados Alemanes y Estados Unidos, Madrid, Librería General de Victoriano Suárez, 1916. Reeditado, POSADA, A.: El régimen municipal de la ciudad moderna, Madrid: Federación Española de Municipios y Provincias, 2007.

POSADA, A.: Tratado de Derecho Administrativo (Madrid, Lib. General de Victoriano Suárez, 1897-98; 2ª ed., 1923).

POSADA, A.: Feminismo, Madrid, Librería de Fernando Fé, 1899. Existe una edición reciente, Eds. Cátedra, Consejería de Educación, Cultura, Deportes y Juventud del Principado de Asturias, 1994.

POSADA, A.: El Instituto del Trabajo (en coautoría con Adolfo Álvarez Buylla y Luis Morote, Madrid, Est.Tipográfico de Ricardo Fe, 1902) (Existe una segunda edición, a cargo de Santiago Castillo, Madrid, Ministerio de Trabajo y Seguridad Social, 1987).

POSADA, A.: "Estudio preliminar" a JELLINEK,G., La declaración de los derechos del hombre y del ciudadano, Madrid, Victoriano Suárez, 1908. POSADA, A.: "Estudio preliminar" originario a JELLINEK,G., La declaración de los derechos del hombre y del ciudadano, edición y adicional estudio introductorio, "Genealogía de las Declaraciones de Derechos y su significación político-jurídica” (pp. VII-XXXVIII), a cargo de J.L. Monereo Pérez, Granada, Comares (Col. Crítica del Derecho), 2009, págs. 1-33.

POSADA, A.: Woodrow Wilson y su obra El Estado, Madrid, Librería General de Victoriano Suárez, 1921.

POSADA, A.: Teoría social y jurídica del Estado. El Sindicalismo (Buenos Aires, Librería J.Méndez, 1922). POSADA, A.: Teoría social y jurídica del Estado. El sindicalismo, edición y estudio preliminar, "Sindicalismo reformista integrado y Estado democrático en el republicanismo social de Adolfo Posada” (pp. IX-LXIV.), al cuidado de J.L. Monereo Pérez, Granada, Comares (Col. Crítica del Derecho), 2018.

POSADA, A.: Actitud ética ante la guerra y la paz, Madrid, Caro Raggio, 1923.

POSADA, A.: España en crisis. La política, Madrid, Caro Raggio, 1923.

POSADA, A.: La Sociedad de Naciones y el Derecho político. Superliberalismo, Madrid, Caro Raggio, 1925.

POSADA, A.: La organización científica del trabajo, Madrid, Sobrinas de suc. de M. Minnesa de los Ríos, 1929.

POSADA, A.: La Nouvelle Constitution Espagnole (Le Régime Constitutionnel en Espagne.-Evolution.-Textes.-Commentaires), París, Bibliothèque Constitutionnelle, Librairie du Recueil Sirey, 1932. POSADA, A.: La nueva constitución española: el régimen constitucional en España. Evolución, textos, comentarios, trad. Antonio María Bueno Armijo, Madrid, Instituto Nacional de Administración Pública, 2006.

POSADA, A.: El Derecho político como espectáculo. Cincuenta años de cátedra (Madrid, Tipográfica de Archivos, 1933). 
POSADA, A.: La crisis del Estado y el Derecho político, Madrid, C.Bermejo, Impresor, 1934 (Adolfo Posada firmaba esta obra con referencia a su condición de Decano de la Facultad de Derecho de la Universidad de Madrid).

POSADA, A.: La idea pura del Estado (Prólogo de Nicolás Pérez Serrano, Madrid, Ed.Rev.de Derecho Privado, 1933, 2a ed., 1944).

POSADA, A.: Leopoldo Alas, “Clarín” (Oviedo, Imprenta La Cruz, 1946).

POSADA, A.: "Recordando al Instituto de Reformas Sociales", Revista del Ministerio de Trabajo y Asuntos Sociales, 1 (2003), pp. 17-25. [Publicado originariamente en la Revista Internacional del Trabajo, «Informaciones Sociales», II, 2, 1930.]

POSADA, A. y PÉREZ SERRANO, N.: Constituciones de Europa y América, 2 Vols., Madrid, Librería General de Victoriano Suárez, 1927.

\subsection{Adolfo González Posada, su pensamiento y época (Selección Instrumental)}

AHRENS, H.: Curso de Derecho natural ó filosofía del Derecho (1870), Madrid, Carlos Bayllu-Bailliere, 1889.

AZCÁRATE,G.DE.: Estudios económicos y sociales, Madrid, Librería de Victoriano Suárez, 1876.

AZCÁRATE,G.DE.: Estudios filosóficos y políticos, Madrid, Imp. de Manuel de los Ríos, 1877.

AZCÁRATE,G.DE.: Minuta de un testamento (Ideario del krausismo liberal), Estudio preliminar y "Addenda-2004” a cargo de Elías Díaz, edición al cuidado de J.L. Monereo Pérez, Granada, Ed.Comares (Col. Crítica del Derecho), 2004.

AZCÁRATE,G.DE.: El régimen parlamentario en la práctica (1885), Ed. E.Tierno Galván, Madrid, Tecnos, 1978.

AZCÁRATE,G.DE.: El concepto de sociología, discurso leído en la Real Academia de Ciencias Morales y Políticas, el 7 de mayo de 1891 (reeditado en la "Revista Española de Investigaciones Sociológicas”, núm.56, 1991, págs.245 a 273).

AZCÁRATE,G.DE.: El problema social. Discurso leído en el Ateneo Científico y Literario de Madrid, el 10 de noviembre de 1893, Madrid, Sucesores de Rivadeneyra, 1893.

AZCÁRATE,G.DE.: Estudios políticos y filosóficos, Madrid, Librería de Alejandro de San Martín, 1877.

AZCÁRATE,P.DE.: La cuestión universitaria. Epistolario de G.Azcárate, F. Giner de los Ríos y N.Salmerón, Madrid, Tecnos, 1967.

AZCÁRATE,G.DE.: Gumersindo de Azcárate. Estudio biográfico y documental. Semblanza. Epistolario, Escritos, Madrid, Tecnos, 1969. 
HAURIOU, M.: Principios de Derecho Público y Constitucional, traducción, estudio preliminar, notas y adiciones por Carlos Ruiz del Castillo, edición al cuidado de J.L. Monereo Pérez, Granada, Comares (Col. Crítica del Derecho), 2003.

GINER DE LOS RÍOS, F.: La persona social. Estudios y fragmentos (1924), edición y estudio preliminar, "El organicismo social de Giner de los Ríos", a cargo de J.L. Monereo Pérez, Granada, Comares (Col. Crítica del Derecho), 2008.

GINER DE LOS RÍOS,F.: Obras Completas de Francisco Giner de los Ríos, veintiún tomos, Madrid, Espasa-Calpe, 1922-1928.

GÓMEZ MOLLEDA, M.D.: Los reformadores de la España contemporánea, Madrid, CSIC, 1966.

JIMENEZ FRAUD,A.: La Institución Libre de Enseñanza, Madrid, Ed.Taurus, 1973.

JIMENEZ LANDI,A.: La Institución Libre de Enseñanza y su ambiente. Tomo I., Madrid, Taurus, 1975; Tomo II, $1^{\circ}$ y $2^{\mathrm{a}}$ parte, Madrid, Taurus, 1987 (Reeditado en 4 tomos,, Madrid, Ministerio de Educación y Cultura, Universidad ComplutenseUniversidad de Barcelona, Universidad de Castilla La Mancha, 1996).

JIMÉNEZ DE ASÚA, L.: Proceso histórico de la Constitución española, Madrid, Reus, 1932; JIMÉNEZ DE ASÚA, L.: La Constitución política de la democracia española, Santiago de Chile, Ediciones Ercilla, 1942.

JIMÉNEZ DE ASÚA, L.: Anécdotas de las constituyentes, Buenos Aires, Cuadernos de Cultura Phac, 1942.

POSADA, A.: Breve historia del krausismo español, Oviedo, Publicaciones de la Universidad de Oviedo, 1981.

POSADA, A.: Fragmentos de mis Memorias, Oviedo, Universidad de Oviedo, Cátedra Aledo, 1983.

PÉREZ SERRANO,N.: Prólogo a POSADA, A.: La idea pura del Estado, Madrid, EDERSA, s.f.(1944).

RUBIO LLORENTE, A.: "Est.prel.," a A.POSADA, Estudios sobre el Régimen Parlamentario en España (Oviedo, Junta General del Principado de Asturias, 1996);

J.J.GIL CREMADES, El reformismo español. Krausismo, Escuela histórica, neotomismo (Barcelona, Ed. Ariel, 1969).

SALMERÓN Y ALONSO,N.: Trabajos filosóficos, políticos y discursos parlamentarios, edición y estudio preliminar, "El republicanismo español: Los supuestos básicos del pensamiento político y social de Nicolás Salmerón", a cargo de J.L.Monereo Pérez, Granada, Ed.Comares (Col. Crítica del Derecho), 2007.

SUÁREZ CORTINA, M.: El reformismo en España. Republicanos y reformistas bajo la Monarquía de Alfonso XIII, Madrid, Siglo XXI, 1986. 
CACHO VIU,V.: La Institución Libre de Enseñanza. I. Origenes y Etapa Universitaria (1860-1881), Madrid, Eds.Rialp, 1962.

CHARLE, Ch: Naissance des “intellectuels”, 1880-1900, Paris, Éd. De Minuit, 1990.

CIMBALI, E.: La nueva fase del derecho civil, trad. de la 2a edición por Francisco Esteban García, Prólogo de D. Felipe Sánchez, Román, Madrid, Tipográfico "Sucesores de Rivadeneira", 1893.

DUGUIT, L.: Manual de Derecho Constitucional, edición y estudio preliminar, «La teoría jurídica de León Duguit», a cargo de José Luis Monereo Pérez y José Calvo González, Granada, Ed. Comares (Col. Crítica del Derecho), 2005.

DUGUIT, L.: Soberanía y libertad, trad. J.G. Acuña, revisión, edición y estudio preliminar, "La soberanía en la modernidad: León Duguit y la "crisis de la soberanía"" (pp. IX-LXXXVI), a cargo de J.L. Monereo Pérez, Granada, Ed. Comares (Col. Crítica del Derecho), 2013.

DUGUIT, L.: Las transformaciones del Derecho público y privado, edición crítica de tres monografías de Leon Duguit vinculadas por la idea-fuerza de las transformaciones del Derecho Público y Privado y el por entonces emergente (en estado naciente) Derecho Social, con estudio preliminar, “'Objetivismo jurídico' y teoría de los “derechos” en León Duguit” (pp. XI-XXXIX), a cargo de J.L. Monereo Pérez y J. Calvo González, Granada, Comares (Col. Crítica del Derecho), 2007.

DUGUIT, L.: Traité de droit constitutionnel, (1927-1930), 3 Tomos , París, Boccard, 1927-1930.

LAPORTA,F.J.: Adolfo Posada. Política y sociología en la crisis del liberalismo español, Madrid, Cuadernos para el Diálogo, 1974.

LASKI, H.J.: La libertad en el Estado moderno, trad. Eduardo Warshaver, revisión, edición y estudio preliminar, "Harold J. Laski y las trayectorias del socialismo democrático en el mundo anglosajón” (pp. IX-XCVII), a cargo de J.L. Monereo Pérez, Granada, Ed. Comares (Col. Crítica del Derecho), 2021.

MARSHALL,T.H.: Ciudadanía y clase social (1950), en MARSHALL,T.H.y BOTTOMORE,T.: Ciudadanía y clase social, Madrid, Alianza, 1998.

MONEREO PÉREZ, J.L.: La reforma social en España: Adolfo Posada, Madrid, Ministerio de Trabajo y Asuntos Sociales, 2003.

MONEREO PÉREZ,J.L.: Fundamentos doctrinales del derecho social en España, Madrid, Trotta, 1999.

MONEREO PÉREZ,J.L.: Los orígenes de la Seguridad Social en España: José Maluquer y Salvador, Granada, Comares, 2007.

MONEREO PÉREZ,J.L.: Sindicalismo reformista integrado y Estado democrático en el republicanismo social de Adolfo Posada, estudio preliminar a POSADA, A.: Teoría social 
y jurídica del Estado. El sindicalismo, edición al cuidado de J.L. Monereo Pérez, Granada, Comares (Col. Crítica del Derecho), 2018, págs. IX-LXIV.

MONEREO PÉREZ, J.L.: “Adolfo Posada (1860-1944)”, en Revista de Derecho de la Seguridad Social Laborum, núm. 2 (2015), págs. 291-301.

MONEREO PÉREZ, «El liberalismo social krauso-institucionista de Juan Uña Sarthou», Civitas. Revista española de derecho del trabajo, núm.140 (2008), págs. 795-820.

MONEREO PÉREZ, J.L.: Derechos sociales de la ciudadanía y ordenamiento laboral, Madrid, Consejo Económico y Social de España, 1996.

MINISTERO DE TRABAJO Y PREVISIÓN SOCIAL: Labor realizada desde la proclamación de la República hasta el 8 de septiembre de 1932, Madrid, Ribadeneyra, s.f. (1932).

MONEREO PÉREZ, J.L: La reforma social en España. Adolfo Posada, Madrid, Ministerio de Trabajo y Asuntos Sociales, 2003.

MONEREO PÉREZ, J.L: Los orígenes de la Seguridad Social en España: José Maluquer y Salvador, Granada, Comares (Col. Crítica del Derecho. Sección Derecho Vivo), 2007.

MONEREO PÉREZ, J.L: Reformismo Social y Socialismo jurídico: Anton Menger y el socialismo jurídico en España, estudio preliminar a MENGER,A.: El Derecho civil y los pobres, Granada, Comares (Col. Crítica del Derecho), 1998, páginas 7 a 112.

MONEREO PÉREZ, J.L: El catolicismo social conservador. Eduardo Sanz y Escartin, Granada, Comares (Col. Crítica del Derecho. Sección Derecho Vivo), 2010, 288 páginas.

MONEREO PÉREZ, J.L: La crisis de la Socialdemocracia Europea. Eduard Bernstein y las premisa del socialismo reformista, Barcelona, Ediciones de Intervención Cultural/El Viejo Topo, 2012.

MONEREO PÉREZ, J.L: "Pedro de Sangro y Ros de Olano (1878-1959)", en Diccionario crítico de juristas españoles, portugueses y latinoamericanos, Peláez, M.J. (Dir.), Parte II, Vol. 1, págs. 498-503, No. 1,0009

MONEREO PÉREZ, J.L: Fundamentos doctrinales del Derecho Social en España, Madrid, Trotta, 1999.

MONEREO PÉREZ, J.L: El pensamiento político-jurídico de Adolfo Posada, estudio preliminar a POSADA, A.: Tratado de Derecho Política, edición crítica íntegra en un solo volumen, a cargo de J.L. Monereo Pérez, Granada, Comares (Col. Crítica del Derecho), 2003, págs. VII a CLXIII.

MONEREO PÉREZ, J.: La democracia en crisis. Harold.J. Laski”, Barcelona, Ediciones de Intervención Cultural/El Viejo Topo, 2005.

MONEREO PÉREZ, J.L.: El Instituto Nacional de Previsión: ubicación histórica, social y político-jurídica, en VV.AA.: Cien años de protección social en España. Libro Conmemorativo del I Centenario del Instituto Nacional de Previsión, TORTUERO 
PLAZA, J.L. (Dir. y Coord.), Madrid, Ed. Ministerio de Trabajo y Asuntos Sociales/Instituto Nacional de la Seguridad Social, 2007, páginas 43-154.

MONEREO PÉREZ, J.L.: El catolicismo social conservador: Eduardo Sanz y Escartín, Granada, Comares, 2010.

MONEREO PÉREZ, J.L: Los (pre)supuestos histórico institucionales de la Seguridad social en la Constitución social del trabajo, en ROJAS RIVERO, G. (Coord.): Orígenes del contrato de trabajo y nacimiento del Sistema de Protección Social, Albacete, Bormarzo, 2012.

MONEREO PÉREZ, J.L: La tradición del marxismo crítico, Granada, Comares (Col. Crítica del Derecho. Sección Derecho Vivo), 2011.

MONEREO PÉREZ, J.L: La democracia en crisis entre las dos guerras mundiales y los desafíos del socialismo democrático: Otto Bauer y la experiencia de la República Austriaca, estudio preliminar a BAUER,O.: Capitalismo y socialismo en la postguerra. Racionalización-Falsa racionalización, Granada, Comares, 2021, págs. IX-XCV.

MONEREO PÉREZ, J.L: Modernidad y capitalismo. Max Weber y los dilemas de la Teoría Política y Jurídica, Barcelona, Ediciones de Intervención Cultural/El Viejo Topo, 2013.

MONEREO PÉREZ, J.L: Espacio de lo político y orden internacional. La teoría política de Carl Schmitt, Ediciones de Intervención Cultural/El Viejo Topo, 2015.

MONEREO PÉREZ, J.L.: Los fundamentos de la democracia. La teoría política de Hans Kelsen, Barcelona, Ediciones de Intervención Cultural/El Viejo Topo, 2013.

MONEREO PÉREZ, J.L: La defensa del Estado Social de Derecho. La teoría política de Hermann Heller, Barcelona, Ediciones de Intervención Cultural/El Viejo Topo, 2009.

MONEREO PÉREZ, J.L: Democracia pluralista y Derecho social. La teoría crítica de Georges Gurvitch, Barcelona, Ediciones de Intervención Cultural/El Viejo Topo, 2021.

MONEREO PÉREZ, J.L: El Derecho en la democracia constitucional. La teoría crítica de Gustav Radbruch", Ediciones de Intervención Cultural/El Viejo Topo, Barcelona, 2020 .

MONEREO PÉREZ, J.L: La dignidad del trabajador. Dignidad de la persona en el sistema de relaciones laborales”, Murcia, Laborum, 2019.

MONEREO PÉREZ, J.L: Harold J. Laski y las trayectorias del socialismo democrático en el mundo anglosajón, estudio preliminar a LASKI, H.J.: La libertad en el Estado Moderno, Granada, Comares (Col. Crítica del Derecho), 2021, págs. IX-XCVII.

MONEREO PÉREZ, J.: Derechos sociales de la ciudadanía y ordenamiento laboral, Madrid, Consejo Económico y Social de España, 1996.

MONEREO PÉREZ, J.L: "Derechos sociales y Estado democrático social en Antón Menger”, estudio preliminar a MENGER, A.: El derecho al producto íntegro del 
trabajo\&El Estado Democrático del Trabajo (El Estado Socialista), edición de J.L. Monereo Pérez, Granada, Comares (Col. Crítica del Derecho), 2004, págs. XI-LXXVIII. MONEREO PÉREZ, J.L: “Los fundamentos del 'liberalismo social' y sus límites: L.T. Hobhouse”, en Civitas. Revista Española de Derecho del Trabajo, núm. 136, OctubreDiciembre, 2007.

MONEREO PÉREZ, J.L: "El pensamiento sociopolítica y pedagógico de Francisco Giner de los Ríos (I y II)", en Revista Española de Derecho Comunitario Europeo. ReDCE. Año 8. Núm. 15-16 (2011), págs. 543 y sigs.

MONEREO PÉREZ, J.L: "El reformismo socio-liberal de Giner de los Ríos. Organicismo y corporativismo social", en Civitas. Revista española de derecho del trabajo, núm. 142 (2009), págs. 279-338.

MONEREO PÉREZ, J.L.: "El pensamiento jurídico-social de Fernando de los Ríos y su generación”, en Gregorio Cámara Villar (ed.): Fernando de los Ríos y su tiempo, Congreso sobre Fernando de los Ríos, Granada, Servicio de Publicaciones de la Universidad de Granada, 2000, págs. 85-136.

MONEREO PÉREZ, J.L.: "El republicanismo español: los supuestos básicos del pensamiento político y social de Nicolás Salmerón", Estudio Preliminar a SALMERÓN Y ALONSO,N.: Trabajos filosóficos, políticos y discursos parlamentarios, Granada, Ed.Comares (Col. Crítica del Derecho), 2007.

MONEREO PÉREZ, J.L.: "Cuestión social y reforma moral: las 'corporaciones profesionales' en Durkheim”, Estudio preliminar a DURKHEIM,E.: Lecciones de sociología. Física de las costumbres y del Derecho, trad. Estela Canto, Granada, Ed.Comares (Col. Crítica del Derecho), 2006.

MONEREO PÉREZ, J.L.: "Razones para actuar: solidaridad orgánica, anomia y cohesión social en el pensamiento de Durkheim”, Estudio preliminar a DURKHEIM,E.: Sociología y filosofía, versión castellana de José María Bolaño (hijo) y revisión de José Luis Monereo Pérez, Granada, Ed.Comares (Col.Crítica del Derecho), 2006.

MONEREO PÉREZ, J.L: Fundamentos doctrinales del socialismo reformista: Eduard Bernstein, estudio preliminar a BERNSTEIN, E.: Socialismo evolucionista, Granada, Comares (Col. Crítica del Derecho), 2011.

MONEREO PÉREZ, J.L: Estado y democracia en Otto Kirchheimer, estudio preliminar a KIRCHHEIMER, O.: Justicia política. Empleo de procedimiento legal para fines políticos, Granada, Comares (Col. Crítica del Derecho), 2001, págs. XIII a CLXXXV.

MONEREO PÉREZ, J.L: “Ricardo Oyuelos y Pérez (1865-1943c): Política Social y Seguridad Social desde el Socialismo Jurídico”, en Revista de Derecho de la Seguridad Social Laborum, núm. 6 (2016).

MONEREO PÉREZ, J.L.: “Adolfo González Posada (1860-1944)”, en Revista de Derecho de la Seguridad Social Laborum, núm. 2 (2015), págs. 291-301. 
MONEREO PÉREZ, J.L.: “Álvaro López Nuñez”, en Revista de Derecho de la Seguridad Social Laborum, núm. 3 (2015), págs. 253-280.

MONEREO PÉREZ, J.L.: “Catolicismo social y previsión social: Álvaro López Nuñez", en Civitas. Revista española de derecho del trabajo, núm. 152 (2011), págs. 907-944.

MONEREO PÉREZ, J.L.: “Carlos González Posada (1890-1948): La teoría del seguro social y su institucionalización en España”, en Revista de Derecho de la Seguridad Social Laborum, núm. 13 (2017).

MONEREO PÉREZ, J.L: “García Ormaechea, R. (1876-1938): Del reformismo democrático iussocialista al reformismo social conservador en la política de Seguridad Social”, en Revista de Derecho de la Seguridad Social Laborum, núm. 14 (2018).

MONEREO PÉREZ, J.L: “Inocencio Jiménez Vicente (9 de noviembre de 1876-27 de abril de 1941): Artífice del desarrollo del Instituto Nacional de Previsión y de la Previsión Social durante la Dictadura de Primo de Rivera y la Segunda República”, en Revista de Derecho de la Seguridad Social Laborum, núm. 20 (2019).

MONEREO PÉREZ, J.L: “Adolfo Álvarez Buylla y González Alegre (1850-1927): La reforma jurídico-social y el aseguramiento público en España desde el republicanismo social y el "socialismo de cátedra"”, en Revista de Derecho de la Seguridad Social Laborum, núm. 24 (2020).

MONEREO PÉREZ, J.L: "Práxedes Zancada y Ruata (1880-1936): La defensa de los seguros sociales obligatorios desde el reformismo político y jurídico y en la derivad del partido reformista, en Revista de Derecho de la Seguridad Social Laborum, núm. 26 (2021).

MONEREO PÉREZ, J.L.: "Eduardo Aunós Pérez (1894-1967): Corporativismo y regeneracionismo autoritario en la política de protección y aseguramiento social", en Revista de Derecho de la Seguridad Social Laborum, núm. 27 (2021).

MONEREO PÉREZ, J.: Democracia social y económica en la metamorfosis del estado moderno: Harold J. Laski, en Lex Social: Revista De Derechos Sociales, 11(1), 298-377. https://doi.org/10.46661/lexsocial.5426.

MONEREO PÉREZ, «El liberalismo social krauso-institucionista de Juan Uña Sarthou», Civitas. Revista española de derecho del trabajo, núm. 140 (2008), págs. 795-820.

MONEREO PÉREZ, J.: El 'Socialismo de cátedra' de Gustav Schmoller en la construcción de la Política social moderna, en Revista Europea de Historia de las Ideas Políticas y de las Instituciones Públicas, 2017, issue 11. https://econpapers.repec.org/article/ervrehipi/y_3a2017_3ai_3a11_3a03.htm

MONEREO PÉREZ, J.: "Inocencio Jiménez Vicente (9 de noviembre de 1876-27 de abril de 1941): Artífice del desarrollo del Instituto Nacional de Previsión y de la previsión social durante la Dictadura de Primo de Rivera y la Segunda República”, en Revista de 
Derecho de la Seguridad Social Laborum, núm. 20 (2019), 267-301, y la bibliografía allí citada.

MONEREO PÉREZ, J.(Dir.): La concertación social en España: una evaluación de su trayectoria en la perspectiva de los cambios socioeconómicos, Autores: Álvarez Gimeno, R., De Val Tena, Á. L., Maldonado Molina, J.A., Monereo Pérez, J.L., Moreno Vida, M.N. y Muñoz de Busillo Llorente, R., Madrid, Consejo Económico y Social de España/Premio de Investigación del Consejo Económico y Social de España, 2015.

MONTOYA MELGAR, A.: Ideología y lenguaje en las leyes laborales de España (18732009), Cizur Menor (Navarra), 2009.

PAYNE, S.G.: La primera democracia española. La Segunda República, 1931-1936, Barcelona, Paidós, 1995.

PALOMEQUE LÓPEZ, M.C.: Derecho del Trabajo e ideología. Medio siglo de formación ideológica del Derecho del Trabajo en España (1873-1923), Madrid, Tecnos, $7^{\mathrm{a}} \mathrm{ed}, 2011$.

PÉREZ SERRANO, N.: La Constitución Española. Antecedentes, texto, comentarios, Madrid, Ed. Revista de Derecho Privado, 1932.

POSADA, A.: Tratado de Derecho Política, edición crítica íntegra en un solo volumen, y estudio preliminar, "El pensamiento político-jurídico de Adolfo Posada" (pp. VII a CLXIII.), a cargo de J.L. Monereo Pérez, Granada, Comares (Col. Crítica del Derecho), 2003.

QUEROL FERNÁNDEZ, F.: La filosofía del Derecho de K.Ch.F. Krause, Madrid, Universidad Pontificia de Comillas, 2000.

MONEREO PÉREZ, J.L.: La organización jurídico-económica del capitalismo. El Derecho de la economía, al libro extraordinario de RIPERT,G.: Aspectos jurídicos del capitalismo moderno, trad.J.Quero Morales, Granada, Ed.Comares (Colección Crítica del Derecho), 2001, págs. XIII-CL.

RADBRUCH, G.: El hombre en el Derecho. Conferencias y artículos seleccionados sobre cuestiones fundamentales del Derecho, trad. Aníbal del Campo, revisión, edición y estudio preliminar, "Gustav Radbruch: un modelo de jurista crítico en el constitucionalismo democrático social” (pp. IX-LXIII), a cargo de J.L. Monereo Pérez, Granada, Comares (Col. Crítica del Derecho), 2020.

RIPERT, G.: El régimen democrático y el derecho civil moderno, trad. José M. Cajica Jr., revisión, edición y estudio preliminar, "Derecho privado y democracia constitucional: Georges Ripert, ¿Paradigma de jurista liberal?”, a cargo de J.L. Monereo Pérez, Granada, Comares (Colección Crítica del Derecho), 2021.

UREÑA, E.M.: Krause, educador de la Humanidad, Madrid, Publicaciones de la Universidad de Comillas-Unión Editorial, 1991. 
VAZQUEZ ROMERO, J.M. (Coord.): Francisco Giner de los Ríos: Actualidad de un pensadora krausista, Madrid, Marcial Pons, 2009.

VARELA SUANZES, J. V.: "El derecho político en Adolfo Posada", Estudios de teoría del Estado y derecho constitucional en honor de Pablo Lucas Verdú, coord. Raúl Morodo Leoncio y Pedro de Vega, Madrid, Servicio de Publicaciones, Facultad de Derecho, Universidad Complutense de Madrid, 2001, vol. 1, págs. 555-580.

VILLA GIL, L.E.: Los orígenes de la Administración Laboral en España, Madrid, Escuela de Administración Pública, 1969.

VV.AA.: Cien años de Protección Social en España. Libro Conmemorativo del Instituto Nacional de Previsión, Tortuero Plaza, J.L. (Dir. y Coord.), Madrid, Ministerio de Trabajo y Asuntos Sociales, 2007.

VV.AA.: La Constitución de Weimar (Texto de la Constitución alemana de 11 de agosto de 1919), Madrid, Tecnos, 2019, con los estudios pioneros de Ottmar Bühler, Walter Jellinek y Costantino Mortati, y la presentación de la edición de Juan Antonio García Amado. 